In cooperation with the Montana Department of Transportation

\title{
Investigation of Pier Scour in Coarse-Bed Streams in Montana, 2001 through 2007
}
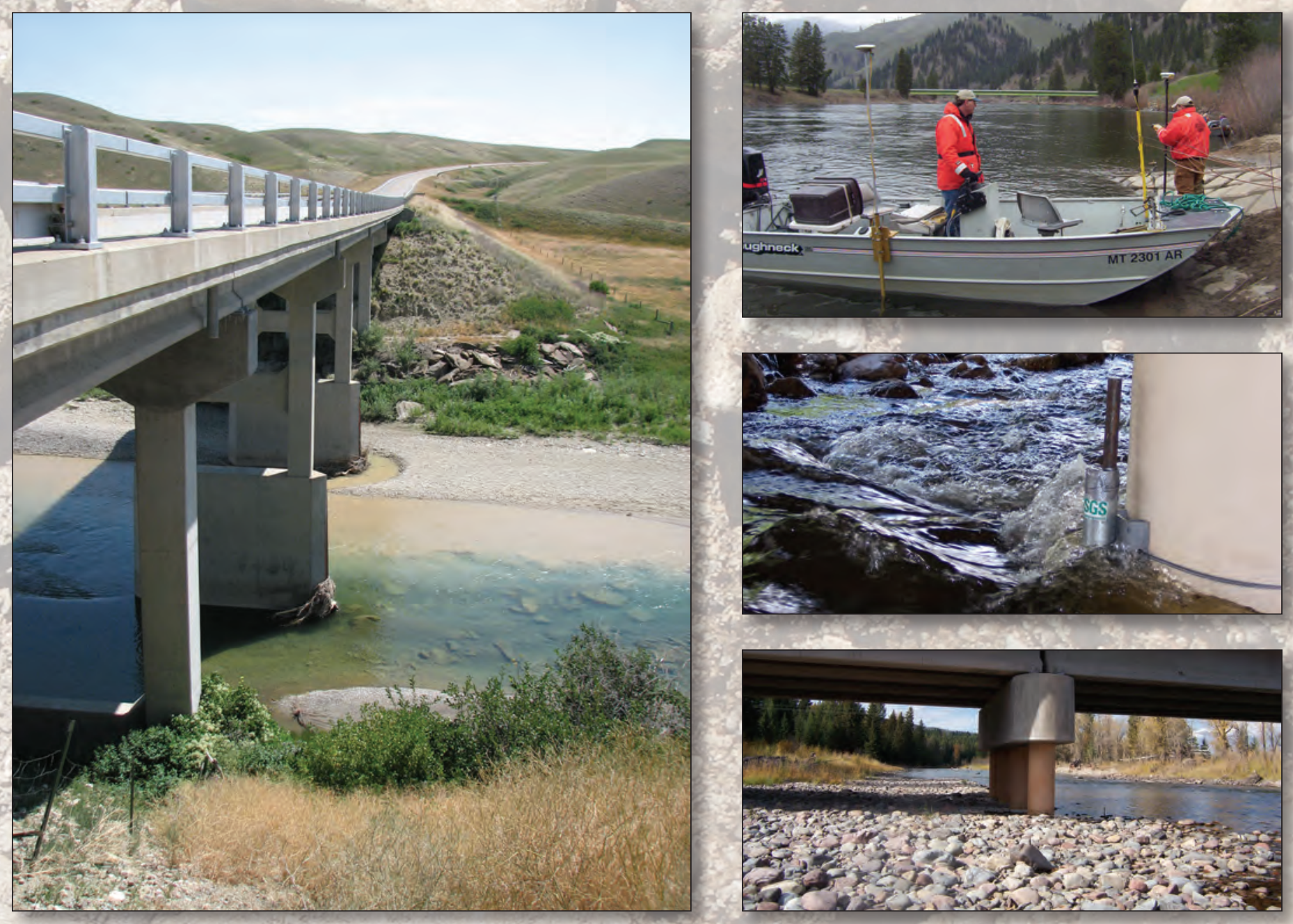

Scientific Investigations Report 2011-5107

U.S. Department of the Interior U.S. Geological Survey 
Front cover. Upper left: Two Medicine River near Browning, Mont., July 2006. Coarse-bed pier scour. Upper right: Clark Fork near Superior, Mont., April 2007. Survey-grade echo sounder and global positioning system (GPS) being used to conduct coarse-bed pier-scour measurements. Center right: Boulder River northwest of Boulder, Mont., June 2006. Scour rod attached to pier. Lower right: North Fork Blackfoot River near Ovando, Mont., October 2006.

Back cover. Landers Fork east of Lincoln, Mont., August 2011. Coarse-bed pier scour. All photographs by Stephen R. Holnbeck, U.S. Geological Survey. 


\section{Investigation of Pier Scour in Coarse-Bed Streams in Montana, 2001 through 2007}

By Stephen R. Holnbeck

In cooperation with the Montana Department of Transportation

Scientific Investigations Report 2011-5107 


\title{
U.S. Department of the Interior \\ KEN SALAZAR, Secretary \\ U.S. Geological Survey \\ Marcia K. McNutt, Director
}

\author{
U.S. Geological Survey, Reston, Virginia: 2011
}

For more information on the USGS - the Federal source for science about the Earth, its natural and living resources, natural hazards, and the environment, visit http://www.usgs.gov or call 1-888-ASK-USGS.

For an overview of USGS information products, including maps, imagery, and publications, visit http://www.usgs.gov/pubprod

To order this and other USGS information products, visit http://store.usgs.gov

Any use of trade, product, or firm names is for descriptive purposes only and does not imply endorsement by the U.S. Government.

Although this report is in the public domain, permission must be secured from the individual copyright owners to reproduce any copyrighted materials contained within this report.

Suggested citation:

Holnbeck, S.R., 2011, Investigation of pier scour in coarse-bed streams in Montana, 2001 through 2007:

U.S. Geological Survey Scientific Investigations Report 2011-5107, 68 p. 


\section{Contents}

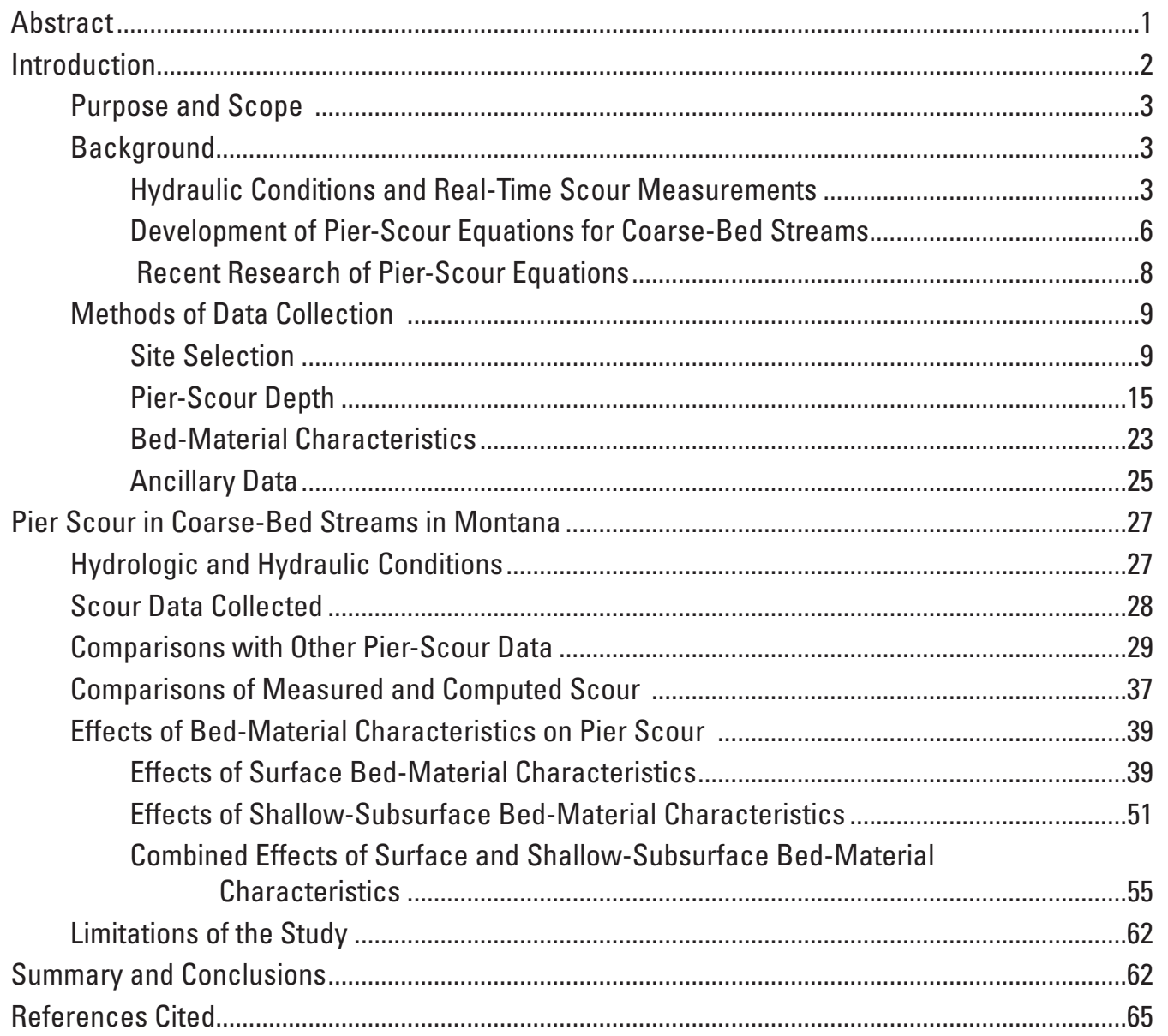

\section{Figures}

1. Map showing location of bridge sites with pier-scour data used for this study ..............4

2. Diagram showing flow field around a bridge pier and principal hydraulic features

3. Graph showing surveyed cross section at upstream side of bridge showing pier-scour holes and reference bed surface used to determine pier-scour depth

4. Photographs showing examples of differences in surface and shallowsubsurface bed material at sites where pier-scour measurements were collected for this study

5. Graph showing pier-scour depth and streamflow measured at site 33, Yellowstone River south of Livingston, Montana (station 06192500),

May and June, 2006.

6. Graph showing comparison of pier-scour measurements collected for this study and from the Bridge Scour Data Management System All dataset 
7. Graph showing comparison of approach velocities for pier-scour measurements collected for this study with the Bridge Scour Data Management

System Coarse and All datasets

8. Graph showing comparison of relative scour velocities for pier-scour measurements collected for this study and from the Bridge Scour Data Management System Coarse dataset

9. Graph showing comparison of bed-material particle size $\left(D_{50}\right.$ and $\left.D_{95}\right)$ for pier-scour measurements collected for this study with the Bridge Scour Data Management System Coarse dataset

10. Graph showing comparison of idealized $K_{4}$ to Mueller velocity-intensity ratios for pier-scour measurements collected for this study, historical pierscour measurements from Montana, and pier-scour measurements in the Bridge Scour Data Management System

11. Graph showing comparison of idealized $K_{4}$ to relative bed-material size for pier-scour measurements collected for this study, historical pier-scour measurements from Montana, and pier-scour measurements in the Bridge Scour Data Management System Coarse dataset.

12. Graphs showing comparison of measured with computed pier-scour depths for data collected for this study using selected pier-scour equations.....

13. Graph showing comparison of residual pier-scour depth for six pier-scour equations evaluated for this study.

14. Graphs showing relation between relative pier scour and relative velocity based on critical velocity for incipient motion of bed material upstream from the bridge; and relative velocity based on critical velocity to initiate scour of bed material at the pier.

15. Graph showing comparison of gradation coefficient for surface bed material for pier-scour measurements collected for this study with the Bridge Scour Data Management System Coarse dataset

16. Graph showing relation between relative pier scour and gradation coefficient for pier-scour measurements collected for this study, historical pier-scour data from Montana, and pier-scour measurements in the Bridge Scour Data Management System All dataset in ripple-forming $\left(D_{50}<0.6\right.$ millimeter $)$ and nonripple-forming $\left(D_{50} \geq 0.6\right.$ millimeter) sediments

17. Graphs showing relation between relative pier scour and relative velocity based on critical velocity for incipient motion of bed material upstream from the bridge; and relative velocity based on critical velocity to initiate scour of bed material at the pier.

18. Graph showing comparison of surface and shallow-subsurface bed-material particle size for pier-scour measurements collected for this study

19. Graph showing comparison of surface with shallow-subsurface bed-material gradation coefficients for pier-scour measurements collected for this study

20. Graph showing relations between corresponding surface and shallowsubsurface bed-material particle size $\left(D_{50}\right.$ and $\left.D_{95}\right)$ for pier-scour measurements collected for this study

21. Graph showing comparison of ratios of surface to shallow-subsurface bedmaterial particle size based on selected percentiles $\left(D_{i}\right)$ from the particlesize distribution curves for each site where pier-scour measurements were collected for this study 
22. Graph showing comparison of residual pier-scour depth based on pier-scour measurements and bed-material data collected for this study with pier-scour depth computed by the HEC-18- $K_{4} \mathrm{Mu}$ equation.

23. Graph showing relation between relative pier scour and relative velocity for different groups of combinations of surface and shallow-subsurface bedmaterial size classifications for the pier-scour measurements collected for this study.

24. Graph showing comparison of relative pier scour to gradation coefficient for surface and shallow-subsurface bed-material data collected for this study

25. Graph showing relation between relative pier scour and relative velocity based on surface and shallow-subsurface bed-material gradation differences for pier-scour measurements collected for this study.

26. Graph showing relation between relative pier scour and relative velocity based on surface and shallow-subsurface bed-material size and gradation differences for pier-scour measurements collected for this study.

\section{Tables}

1. Bridge sites where pier-scour measurements were made for this study .......................10

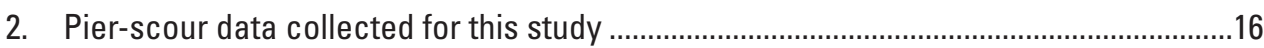

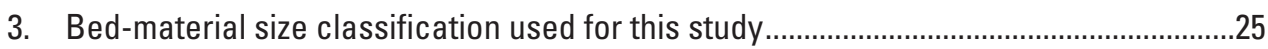

4. Variation in surface bed-material particle size for multiple pebble counts made at bridge sites where pier-scour measurements were made for this study ....................26

5. Summary statistics for pier-scour measurement data collected for this study...............30

6. Comparison of the relative bed-material size associated with pier-scour measurements made in this study with the Bridge Scour Data Management System All dataset.

7. Comparison of bed-material size classification associated with pier-scour measurements made for this study and measurements from the Bridge Scour Data Measurement System Coarse and All datasets

8. Selected historical pier-scour measurements (1996-97) used in this study

9. Particle-size distribution and gradation coefficient for surface and shallowsubsurface bed-material data collected for this study

10. Percentage of pier-scour measurements with a gradation coefficient greater than 2.5

11. Statistical summary of measured pier scour and computed pier scour based on surface and shallow-subsurface bed-material data

12. Groups of pier-scour measurements based on classification of particle sizes of the surface and shallow-subsurface bed material 


\section{Conversion Factors, Datum, Abbreviations, Symbols, and Variables}

\begin{tabular}{|c|c|c|}
\hline Multiply & By & To obtain \\
\hline \multicolumn{3}{|c|}{ Length } \\
\hline inch (in.) & 2.54 & centimeter $(\mathrm{cm})$ \\
\hline inch (in.) & 25.4 & millimeter $(\mathrm{mm})$ \\
\hline foot $(\mathrm{ft})$ & 0.3048 & meter $(\mathrm{m})$ \\
\hline mile (mi) & 1.609 & kilometer $(\mathrm{km})$ \\
\hline \multicolumn{3}{|c|}{ Area } \\
\hline square mile $\left(\mathrm{mi}^{2}\right)$ & 259.0 & hectare (ha) \\
\hline square mile $\left(\mathrm{mi}^{2}\right)$ & 2.590 & square kilometer $\left(\mathrm{km}^{2}\right)$ \\
\hline \multicolumn{3}{|c|}{ Flow rate } \\
\hline foot per second (ft/s) & 0.3048 & meter per second $(\mathrm{m} / \mathrm{s})$ \\
\hline cubic foot per second $\left(\mathrm{ft}^{3} / \mathrm{s}\right)$ & 0.02832 & cubic meter per second $\left(\mathrm{m}^{3} / \mathrm{s}\right)$ \\
\hline foot per second squared $\left(\mathrm{ft} / \mathrm{s}^{2}\right)$ & 0.3048 & meter per second squared $\left(\mathrm{m} / \mathrm{s}^{2}\right)$ \\
\hline \multicolumn{3}{|c|}{ Hydraulic gradient } \\
\hline foot per foot $(\mathrm{ft} / \mathrm{ft})$ & 1.0 & meter per meter $(\mathrm{m} / \mathrm{m})$ \\
\hline foot per mile ( $\mathrm{ft} / \mathrm{mi})$ & 0.1894 & meter per kilometer $(\mathrm{m} / \mathrm{km})$ \\
\hline
\end{tabular}

Temperature in degrees Fahrenheit $\left({ }^{\circ} \mathrm{F}\right)$ may be converted to degrees Celsius $\left({ }^{\circ} \mathrm{C}\right)$ as follows:

${ }^{\circ} \mathrm{C}=\left({ }^{\circ} \mathrm{F}-32\right) / 1.8$

Vertical coordinate information for study data corresponds to the North American Vertical Datum of 1988 (NAVD 88).

Horizontal coordinate information for study data corresponds to the North American Datum of 1983 (NAD 83) except for figure 1, which corresponds to the North American Datum of 1927 (NAD 27).

Elevation, as used in this report, refers to distance above the vertical datum or local datum.

\section{Acronyms used in this report:}

$\begin{array}{ll}\text { ADCP } & \begin{array}{l}\text { acoustic Doppler current profiler } \\ \text { BSDMS }\end{array} \\ \text { BSDMS All } & \begin{array}{l}\text { Bridge Scour Data Management System, U.S. Geological Survey bridge scour } \\ \text { database } \\ \text { the Montana study }\end{array} \\ \text { BSDMS Coarse } & \begin{array}{l}\text { All BSDMS pier-scour data meeting further coarseness criteria of } \\ D_{50} \geq 2 \text { millimeters and } D_{95} \geq 20 \text { millimeters }\end{array} \\ \text { CSU } & \text { Colorado State University } \\ \text { FISP } & \text { Federal Interagency Sedimentation Project } \\ \text { FHWA } & \text { Federal Highway Administration }\end{array}$




$\begin{array}{ll}\text { GPS } & \text { global positioning system } \\ \text { HEC-18 } & \text { Hydraulic Engineering Circular No. } 18 \\ \text { IR } & \text { interquartile range } \\ \text { MDT } & \text { Montana Department of Transportation } \\ \text { USGS } & \text { U.S. Geological Survey }\end{array}$

\section{Symbols and variables used in this report:}

\begin{tabular}{|c|c|}
\hline$=$ & equal to \\
\hline$\approx$ & approximately equal to \\
\hline$<$ & less than \\
\hline$>$ & greater than \\
\hline$\leq$ & less than or equal to \\
\hline$\geq$ & greater than or equal to \\
\hline$b$ & effective width of the pier measured perpendicular to the approach flow, in feet \\
\hline$b_{n}$ & nominal pier width measured perpendicular to the pier length, in feet \\
\hline$b / D_{50}$ & relative bed-material size, dimensionless \\
\hline$D$ & bed-material particle size, in millimeters or feet \\
\hline$D_{C F}$ & particle size for the coarse size fraction of the bed material, in millimeters or feet \\
\hline$D_{i}$ & $\begin{array}{l}\text { bed-material particle size, } D \text {, where } i \text { percent of particles are finer by weight, in } \\
\text { millimeters or feet }\end{array}$ \\
\hline$D_{i, s}$ & $\begin{array}{l}\text { surface bed-material particle size, } D \text {, where } i \text { percent of particles are finer by } \\
\text { weight, in millimeters or feet }\end{array}$ \\
\hline$D_{i, s s}$ & $\begin{array}{l}\text { shallow-subsurface bed-material particle size, } D \text {, where i percent of particles } \\
\text { are finer by weight, in millimeters or feet }\end{array}$ \\
\hline$F_{r}$ & Froude number directly upstream from the pier, $\frac{V_{o}}{\sqrt{g y_{o}}}$, dimensionless \\
\hline$g$ & acceleration due to gravity, in feet per second squared \\
\hline$I_{v}$ & $\begin{array}{l}\text { bed-material variability index that expresses the difference between the } \\
\text { surface- and shallow-subsurface bed-material, as measured by the variables } \\
D_{50}, D_{95} \text {, and } \sigma_{g} \text {; dimensionless }\end{array}$ \\
\hline Idealized $K_{4}$ & $\begin{array}{l}\text { relative error between pier-scour depth from field measurements and pier-scour } \\
\text { depth computed by an equation, dimensionless }\end{array}$ \\
\hline$K_{1}$ & correction factor for pier-nose shape, dimensionless \\
\hline$K_{2}$ & correction factor for flow angle of attack on the pier, dimensionless \\
\hline$K_{3}$ & correction factor for bed-form condition, dimensionless \\
\hline$K_{4}$ & $\begin{array}{l}\text { correction factor for the coarse bed-material armoring effect on pier-scour } \\
\text { depth, dimensionless }\end{array}$ \\
\hline$K_{c}$ & a constant equal to 12.0, in inch-pound units \\
\hline
\end{tabular}




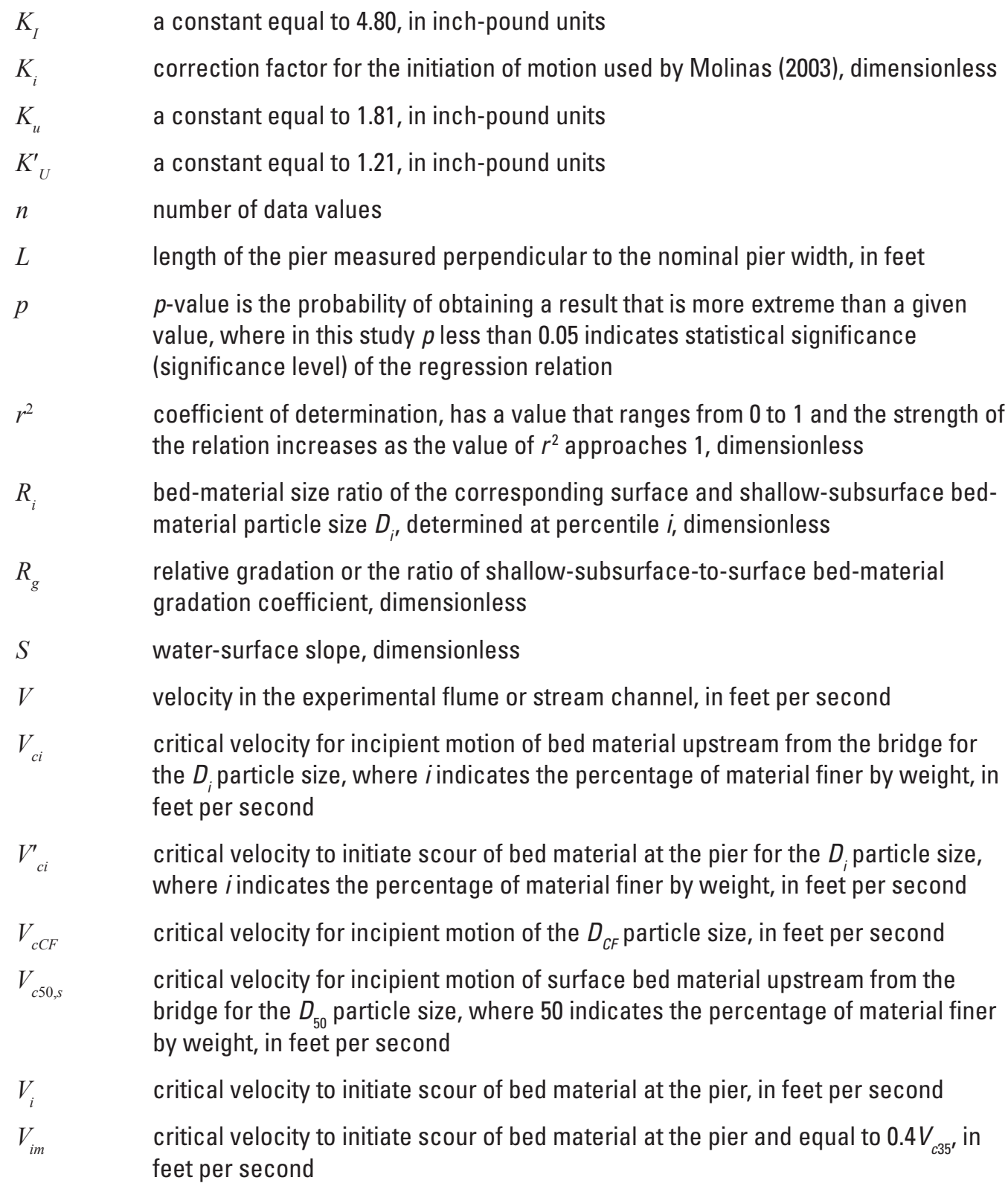


$V_{o} \quad$ approach velocity directly upstream from the pier, in feet per second

$V_{o} / V_{c 50} \quad$ relative velocity associated with incipient motion of bed material upstream from the bridge, dimensionless

$V_{o} / V_{c 50}^{\prime} \quad$ relative velocity associated with initiation of scour of bed material at a pier, dimensionless

$V_{R} \quad$ velocity-intensity ratio, dimensionless

$V_{R M} \quad$ Mueller velocity-intensity ratio, dimensionless

$y_{o} \quad$ approach depth of flow just upstream from the pier, in feet

$y_{o} / b \quad$ relative flow depth, dimensionless

$y_{s} \quad$ pier-scour depth computed by an equation, in feet

$y_{s}^{\prime} \quad$ pier-scour depth from field measurements, in feet

$y_{s}^{\prime} / b \quad$ relative pier scour, dimensionless

$y_{s}^{\prime} y_{s} \quad$ idealized $K_{4}$ or relative error in computed scour $\left(y_{s}\right)$ based on measured pier scour $\left(y^{\prime}\right)$, dimensionless

$\alpha \quad$ flow angle of attack on the pier, in degrees

$\psi \quad$ velocity-intensity ratio used by Molinas (2003), dimensionless

$\sigma_{g} \quad$ gradation coefficient of the bed material, $\sqrt{\frac{D_{84}}{D_{16}}}$, dimensionless

$\sigma_{g, s} \quad$ gradation coefficient of the surface bed material, $\sqrt{\frac{D_{84}}{D_{16}}}$, dimensionless

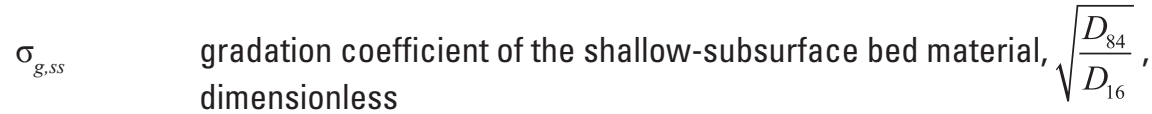

$\sigma_{g, c} \quad$ composite gradation coefficient or geometric mean of the corresponding surface gradation coefficient $\left(\sigma_{g, s}\right)$ and shallow subsurface gradation coefficient $\left(\sigma_{g, s s}\right)$, dimensionless

$\theta \quad$ Shields parameter, dimensionless 



\title{
Investigation of Pier Scour in Coarse-Bed Streams in Montana, 2001 through 2007
}

\author{
By Stephen R. Holnbeck
}

\section{Abstract}

Determination of pier-scour potential is an important consideration in the hydraulic analysis and design of highway bridges that cross streams, rivers, and other waterways in the United States. A primary goal of ongoing research in the field of bridge scour is to improve scour-prediction equations so that pier-scour depth is neither underpredicted nor excessively overpredicted. Scour depth for piers in noncohesive, nonuniform streambeds with a mixture of sand, gravel, cobbles, and boulders (coarse-bed streams) generally is less than the scour depth in finer-grained (mostly sand) streambeds under similar hydraulic conditions. The difference in scour depth is attributed to formation of an armor layer. Pier-scour data collected by the U.S. Geological Survey were used to develop a bed-material correction factor called $K_{4}$. The equation recommended by the Federal Highway Administration for computing pier scour is a version of the HEC-18 pier-scour equation that includes $K_{4}$, which is referred to in this report as the HEC-18- $K_{4} \mathrm{Mu}$ equation. The Montana Department of Transportation was interested in pier-scour prediction in coarse-bed streams because coarse-bed streams are common in Montana. Consequently, the U.S. Geological Survey and the Montana Department of Transportation began a cooperative study in 2001 to investigate pier scour in coarse-bed streams in Montana.

This report describes results of a study of pier scour in coarse-bed streams at 59 bridge sites during 2001-07 in the mountain and foothill regions of Montana. Drainage areas for the streams at bridge sites where measurements were collected ranged from about 3 square miles $\left(\mathrm{mi}^{2}\right)$ to almost $20,000 \mathrm{mi}^{2}$. Data collected and analyzed for this study include 103 coarsebed pier-scour measurements. The report also describes how coarse-bed pier-scour measurements were collected, shows the extent that the coarse portion of the national pier-scour database was expanded, discusses how these new data were used to evaluate the relative accuracy of various equations for predicting scour in coarse-bed streams, and demonstrates how differences in size and gradation between surface bed material and bed material underlying the surface layer (shallowsubsurface bed material) might relate to pier scour.
Ninety-six out of 103 pier-scour measurements were made under clear-water scour conditions, when the streambed upstream from the bridge is stable and there is no substantial incoming sediment supply to the bridge opening. Of the measurements made, 50 percent had an approach velocity $\left(V_{o}\right)$ that equaled or exceeded 70 percent of the critical velocity $\left(V_{c 50}\right)$ for incipient motion of bed material, which might indicate that scour was measured very near the threshold between clearwater and live-bed scour $\left(V_{o} / V_{c 50}\right.$ equal to 1.00) where maximum scour was shown in laboratory studies.

Pier-scour data collected for this study were compared to selected pier-scour data from the Bridge Scour Data Management System (BSDMS), a database of scour measurements made nationwide, to show the effect of bed-material size and gradation on scour depth. The relation between relative pier scour $\left(y_{s}^{\prime} / b\right)$, or the ratio of measured pier scour $\left(y_{s}^{\prime}\right)$ to effective pier width $(b)$, and relative velocity $\left(V_{o} / V_{c 50}\right)$ defined by an envelope curve for data collected for this study and the BSDMS data were compared to relations observed in laboratory data. The envelope curve for data used for this study displays an earlier peak, with a decrease in relative pier scour followed by an asymptotic rise. Interestingly, the first peak in the curve occurs at a lower relative velocity $\left(V_{o} / V_{c 50}\right.$ about $0.75)$ than the clear-water and live-bed threshold $\left(V_{o} / V_{c 50}\right.$ equal to 1.00). Also, the magnitude of this peak (maximum of 1.25 ) is much less than the published maximum value of 2.4 obtained from laboratory data. Furthermore, equilibrium livebed scour is about 18 percent shallower than the maximum pier scour under clear-water conditions, a larger reduction than the 10 percent indicated in published research. Armoring associated with nonuniform coarse-bed material and unsteadyflow conditions in the field probably accounts for differences between envelope curves developed for this study and those from previous studies conducted in the laboratory using finegrained material and steady-flow conditions.

Scour depth was computed for the measurements collected for this study using the HEC-18 equation without the $K_{4}$ correction factor and five pier-scour equations that use $K_{4}$ for the armoring effect of coarse bed material. The HEC-18- $K_{4} \mathrm{Mu}$ equation was the best equation for predicting pier-scour depth in coarse-bed streams because the equation generally predicted pier scour in closer agreement to measured scour 
than the other equations used for computing pier-scour depth. Furthermore, the magnitude of the residuals of underpredicted and overpredicted scour depth was the lowest using the HEC-18- $K_{4} \mathrm{Mu}$ equation.

Gradation coefficients $\left(\sigma_{g}\right)$ for the surface bed-material data collected for this study ranged from 1.48 to 4.14, with a median of 2.01. For data used in this study, maximum relative pier scour was greater when $\sigma_{g}$ was less than or equal to about 2.5. Pier-scour measurements collected for this study and BSDMS confirm a general lack of data for coarse-bed sites with $\sigma_{g}$ greater than about 2.5 .

Paired samples of surface and shallow-subsurface bed material collected for this study were analyzed and the $D_{50}$ and $D_{95}$ particle sizes were compared. Median $D_{50}$ particle sizes for 103 surface and shallow-subsurface bed-material samples were about 49 millimeters $(\mathrm{mm})$ and $32 \mathrm{~mm}$, respectively, and median $D_{95}$ particle sizes for 103 surface and shallow-subsurface bed material samples were $122 \mathrm{~mm}$ and $86 \mathrm{~mm}$, respectively. The median gradation coefficients for surface and shallow-subsurface bed material associated with measurements made for this study were 2.01 and 4.14, respectively. The frequency and magnitude of the residual pier-scour depth associated with underpredicted and overpredicted scour was about the same regardless of whether surface or shallow-subsurface particle-size data were used with the HEC-18- $K_{4} \mathrm{Mu}$ equation.

The combined effect that surface and shallow-subsurface bed-material characteristics might have on measured pier scour also was examined. The combined influence of relative differences in surface and shallow-subsurface bed-material size and gradation on pier scour was investigated by defining a bed-material variability index $\left(I_{v}\right)$ based on ratios of particle sizes and gradation coefficients between layers for each of the 103 pier-scour measurements. Selected percentiles were determined and the relative pier scour and relative velocity for each measurement in the percentile were plotted. Envelope curves bounding the measurements in each percentile were drawn. Maximum relative pier scour associated with each envelope curve was concentrated at about the same relative velocity. Based on these curves, as differences in particle size and gradation between the surface and shallow-subsurface bed-material layers increase (higher values of $I_{v}$ ), pier scour decreases.

Runoff conditions during the study mostly were limited to bankfull discharge approximating the 1.5- to 2-year recurrence-interval flood, which have a 67- and 50-percent chance, respectively, of happening in any year. Lack of higher flows having greater velocity intensities may indicate that scour depths were limited by hydrologic conditions. Pier-scour depths measured in this study also may have been limited by streambed armoring and unsteady flow conditions. Conclusions presented for this study are generally limited to the range of hydraulic conditions and bed-material characteristics demonstrated in the data collected for this study and the BSDMS data.

\section{Introduction}

Determination of pier-scour potential is an important consideration in the hydraulic analysis and design of highway bridges that cross streams, rivers, and other waterways in the United States. Existing bridges continue to undergo scour assessments as part of a national program, and pier scour is among the key scour components investigated. Bridge rehabilitation and the design of new bridges require that pier footings be located below the scour zone of the streambed during large floods. Pier-scour depth is commonly computed using empirical equations, with many different equations having been developed over the years. Such equations were traditionally based on studies conducted in hydraulic laboratories using flumes and scaled pier models. Scale effects associated with model studies restricted the maximum bed-material particle size to mostly noncohesive sand. A primary goal of ongoing bridge scour research is to improve laboratory-based scourprediction equations using field-scale data so that pier-scour depth is neither underpredicted nor excessively overpredicted. Underpredicted pier scour can result in pier footings not being located deep enough in the streambed to resist scour. Scour during large floods could, therefore, undermine pier footings and result in damage or instability to the bridge and possibly catastrophic failure. Overpredicted pier scour might indicate that more bridges are scour critical, or prone to failure due to scour, than is actually the case and thus may lead to expensive over-design or unnecessary retrofitting of pier foundations (Chase and Holnbeck, 2004). Research efforts, therefore, continue to evaluate and improve the accuracy of pier-scour equations.

Since the early 1990s, research has expanded to include field measurements of pier scour during high-flow conditions. These scour measurements enable pier-scour equations to be evaluated beyond the theoretical or limited laboratory conditions frequently used in equation development. Mueller (1996) and Mueller and Jones (1999) studied bed-material size and gradation effects on pier-scour depth in noncohesive streambeds. Their research indicated that scour depth for piers in noncohesive, nonuniform streambeds with a mixture of sand, gravel, cobbles, and boulders (coarse-bed streams) generally is less than the scour depth in finer-grained (mostly sand) streambeds under similar hydraulic conditions. The difference in scour depth is attributed to formation of an armor layer (Shen and others, 1966). This finding, supported by field measurements collected by the U.S. Geological Survey (USGS), has led to modifications in the scour equations recommended by the Federal Highway Administration (FHWA). Pier-scour data collected by the USGS were used to develop a bed-material correction factor called $K_{4}$. Collection of additional coarsebed pier-scour data was recommended to further validate the method for computing $K_{4}$ and to provide additional data for continued evaluation of pier-scour equations (Mueller and Jones, 1999). As recently as 2005, Mueller and Wagner (2005) noted that relations and equations developed from laboratory research had not been adequately verified with field data. 
Much advancement has been made since the mid-1990s in the research and development of equations that account for coarse-bed pier scour, but additional data were needed to evaluate whether these equations accurately predicted scour in coarse-bed streams.

The Montana Department of Transportation (MDT) was interested in pier-scour prediction in coarse-bed streams because coarse-bed streams are common in Montana. Furthermore, the USGS has collected bridge-scour data and conducted bridge-scour investigations in Montana since the early 1990s in cooperation with MDT. Consequently, the USGS and MDT began a cooperative study in 2001 to investigate pier scour in coarse-bed streams in Montana.

\section{Purpose and Scope}

This report presents the results of a study of pier scour in coarse-bed streams at 59 bridge sites during 2001-07 in the mountain and foothill regions of three major river basins in Montana: the Missouri, Yellowstone, and Clark Fork of the Columbia (fig. 1). Additionally, the report:

1. Describes how coarse-bed pier-scour measurements were collected.

2. Shows the extent to which the coarse portion of the national pier-scour database used for conducting scour research was expanded.

3. Discusses how these new data were used to evaluate the relative accuracy of various equations for predicting scour in coarse-bed streams.

4. Demonstrates how differences in size and gradation between surface bed material and bed material underlying the surface layer, referred to in this report as shallow-subsurface bed material, might relate to pier scour.

Drainage areas for the streams at bridge sites where measurements were made ranged from about $3 \mathrm{mi}^{2}$ to almost $20,000 \mathrm{mi}^{2}$. Data collected and analyzed for this study include 103 coarse-bed pier-scour measurements and represent a substantial sample of coarse-bed streams in Montana. When these data are added to the USGS Bridge Scour Data Management System (BSDMS) database at the conclusion of the study, the number of coarse-bed pier-scour measurements in the current (2011) database will increase substantially.

Field methods (Jarrett and Boyle, 1986; Landers and Mueller, 1996; and Mueller and Landers, 2000), hereinafter referred to as limited-detail field procedures, and equipment ranging from simple scour rods to complex hydroacoustic instrumentation were used to obtain pier-scour measurements. Pier-scour measurements were made during spring snowmelt runoff when streamflow and hydraulic conditions generally approximated bankfull discharge with recurrence intervals of 1.5 to 2 years, which have a 67 - and 50-percent chance, respectively, of happening in any year. Pier-scour measurements also were made during low-flow conditions. Because the low-flow measurements are considered ancillary, only the high-flow measurements are presented and discussed in the report. Selected Montana pier-scour measurements for peak streamflows (5- to about 100-year recurrence interval) obtained prior to this study also were used as an independent check on envelope curves developed similar to those from previous studies (Ettema, 1980; Melville, 1984; Chiew, 1984; and Mueller and Wagner, 2005). The envelope curves have either linear or curvilinear shape and define an upper boundary to the data.

In this report, gradation and gradation coefficient $\left(\sigma_{g}\right)$ are terms frequently used to describe and measure the variation in particle-size distribution of the bed material. Bed material is considered to be poorly graded or has a smaller gradation (also referred to as well sorted) when the material is more uniform, or has a narrow range of grain sizes. Bed material is considered to be well graded or has a larger gradation (also referred to as poorly sorted) when the material is nonuniform, or has a wider range of grain sizes. The magnitude of the gradation coefficient increases as gradation increases or as the range in particle sizes increases.

Because bed armoring relates to surface and subsurface particle-size differences, surface and shallow-subsurface bedmaterial data were collected at each site. Particle-size gradation was determined from pebble counts and sieve analyses. Surface and shallow-subsurface bed material sampled during this study were used to evaluate the sensitivity of computed scour to size and gradation differences between the two layers. Data for each layer also were used to assess the effects of bedmaterial characteristics on measured pier scour.

Mathematical symbols $(=, \approx,<,>, \leq$, and $\geq$ ) used in this report are defined near the front of the report under the section "Symbols and variables used in this report," and are either spelled out or appear as the symbol thereafter in the body of the report. Variable symbols used in this report (for example, $y_{o}, D_{i}$, and $V_{o}$ ) are defined near the front of the report under the section "Symbols and variables used in this report," and at first occurrence and occasionally thereafter in the body of the report.

\section{Background}

\section{Hydraulic Conditions and Real-Time Scour Measurements}

The relative stability of a streambed is related to hydraulic conditions in the stream and the particle sizes of the streambed material. Scour at a bridge pier depends on the stability of the streambed near the bridge, the extent of bedmaterial transport from upstream, and forces acting on the streambed near the pier that result from the interaction of the stream and the pier. Pier scour can occur when the streambed upstream from the bridge is stable and there is no substantial incoming sediment supply to the bridge opening (clear-water 


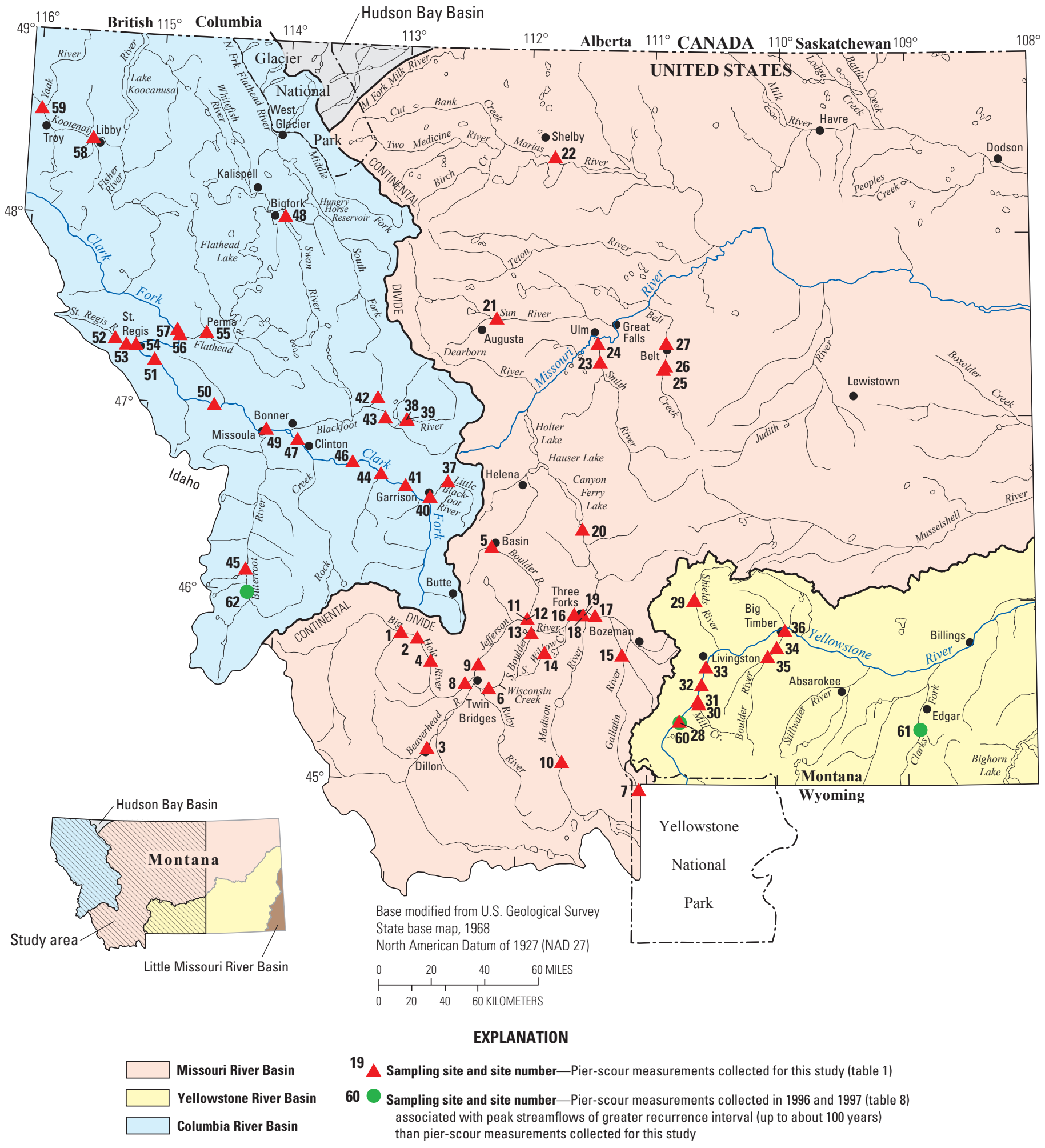

Figure 1. Location of bridge sites with pier-scour data used for this study. 
scour) and when the streambed is unstable and bed material is actively being transported by the stream into the bridge opening from upstream (live-bed scour). Documenting the stream stability and sediment-transport conditions associated with each pier-scour measurement is necessary to improve understanding of the processes contributing to pier scour. In order to develop equations relating scour and hydraulic conditions, pier scour measured in the field must be the result of hydraulic conditions at the time of measurement (real-time scour).

The critical velocity for incipient motion of bed material $\left(V_{c i}\right)$ is used to determine if clear-water or live-bed conditions predominate upstream from a bridge site (Richardson and Davis, 1995, p. 12-13), with observed velocity less than $V_{c i}$ indicating clear-water scour and observed velocity greater than $V_{c i}$ indicating live-bed scour:

$$
V_{c i}=31.08 \theta^{1 / 2} K_{u} y_{o}^{1 / 6} D_{i}^{1 / 3}
$$

where

$$
\begin{gathered}
\theta \quad \begin{array}{c}
\text { is the Shields parameter, dimensionless, based } \\
\text { on particle size and hydraulic conditions; }
\end{array} \\
K_{u} \quad \begin{array}{c}
\text { is a constant equal to } 1.81 \text { for inch-pound } \\
\text { units, dimensionless; }
\end{array} \\
y_{o} \quad \text { is the approach depth of flow just upstream } \\
\text { from the pier, in feet for this equation; and } \\
D_{i} \quad \begin{array}{c}
\text { is the bed-material particle size } D, \text { in feet for } \\
\text { this equation, where } i \text { percent of particles }
\end{array} \\
\text { are finer by weight. }
\end{gathered}
$$

Equation 1 is commonly applied to determine the critical velocity for any particle size in the streambed. For incipient motion, the median or $D_{50}$ particle size and corresponding $\theta$ typically are used to determine stream stability. Clear-water scour often occurs in streams with coarse bed material.

Pier scour is a local scour process resulting from vortex action and flow acceleration when flow is obstructed by the pier. The vortex systems produced are complex threedimensional flow fields that can act as continuous or intermittent energy systems that vary with hydraulic conditions. The two primary vortices involved are the horseshoe vortex and the wake vortex (fig. 2). The horseshoe vortex forms near the upstream base of the pier as flow impinges and moves down the pier face and along the sides of the pier. The wake vortex forms as shearing layers of flow detach from the sides of the pier and move downstream away from the pier, which results in bed material being carried or scoured away (Melville, 1995).
The equation by Gao and others (1993) is used to compute the critical velocity to initiate scour of bed material at the pier $\left(V_{c i}^{\prime}\right)$ based on the critical velocity for incipient motion of bed material upstream from the bridge $\left(V_{c i}\right.$, equation 1$)$ :

$$
V_{c i}^{\prime}=0.645\left(\frac{D_{i}}{b_{n}}\right)^{0.053} V_{c i},
$$

where

$$
\begin{aligned}
& b_{n} \quad \text { is the nominal pier width measured } \\
& \text { perpendicular to the pier length, which } \\
& \text { takes on the units of } D_{i} \text { in this equation } \\
& \text { (feet); }
\end{aligned}
$$

and where all other terms are as previously defined. By this equation, the velocity to initiate scour of bed material at the pier is about one-half the velocity for incipient motion of bed material in the channel upstream from the bridge.

Equation 2 is used to determine if a valid real-time measurement of pier-scour was made in the field. Measurements (scour depth, flow velocity, and flow depth) made at remnant scour holes under base or moderate flows do not reflect the true hydraulic conditions accounting for the geometry of the scour hole. The measured approach velocity $\left(V_{o}\right)$ is compared Pier
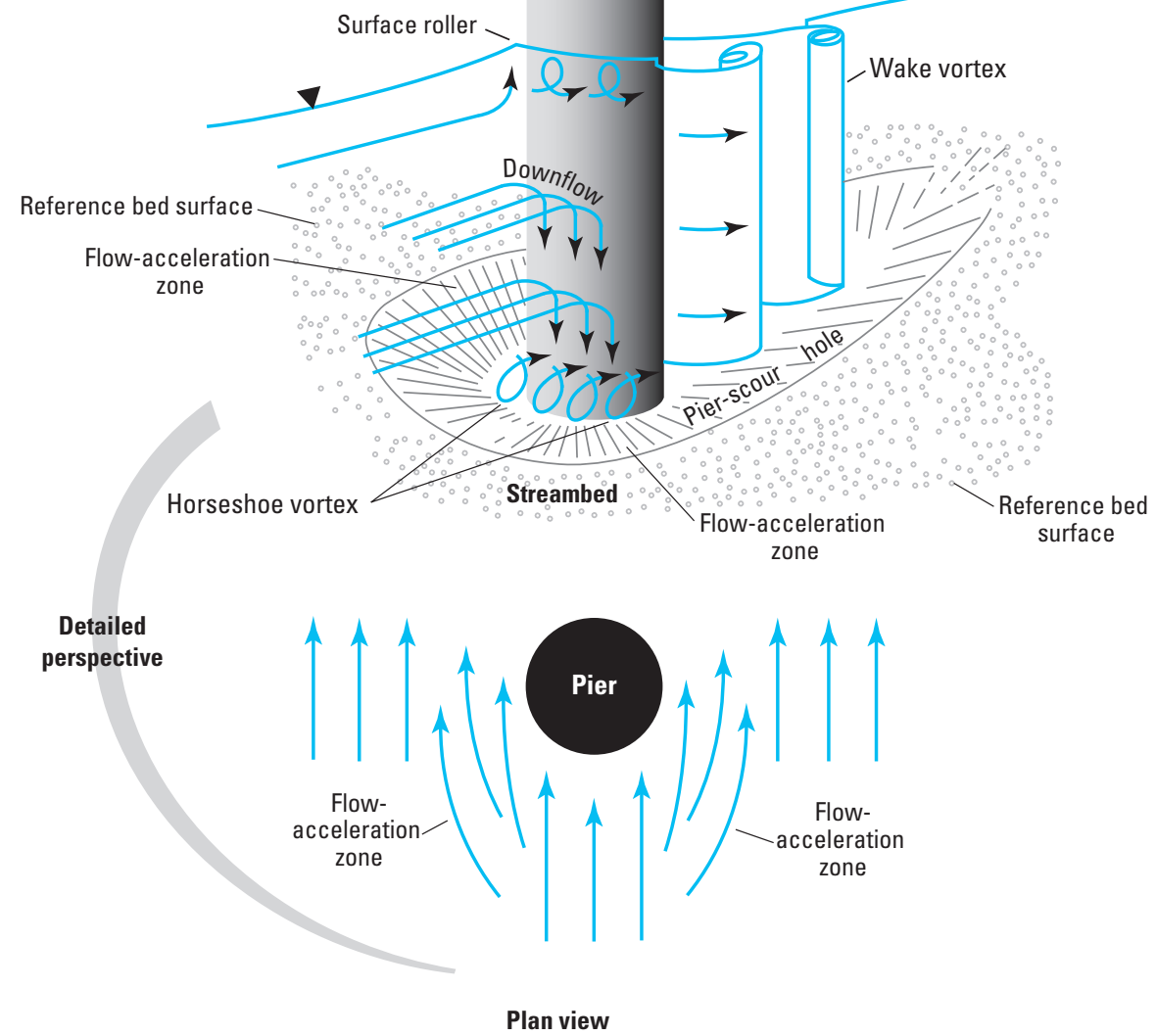

Figure 2. Flow field around a bridge pier and principal hydraulic features (modified from Melville, 1995). 
to the critical velocity $\left(V^{\prime}{ }_{c 0}\right)$ to initiate scour of the $D_{50}$ particle size computed by equation 2 , to determine if the hydraulic conditions at the time of measurement are sufficient to cause pier scour, according to the following criteria:

1. If $V_{o}>V_{c 50}^{\prime}$, a valid real-time scour measurement was made because bed material can scour at the pier under the observed conditions, or

2. If $V_{o} \leq V_{c 50}^{\prime}$, a valid real-time scour measurement was not made because bed material cannot scour at the pier under the observed conditions.

Under clear-water conditions, scour continues to develop until the scour hole becomes armored, and the resulting scour is referred to as maximum-local-pier scour. Under live-bed conditions, scour continues to develop until the rate of sediment transport out of the scour hole equals the rate of sediment transport into the scour hole, or the scour hole becomes armored and the stream velocity is insufficient to transport the size of bed material in contact with flow (Richardson and Davis, 2001). Scour depth under live-bed conditions tends to fluctuate around a mean-depth value over time, partly due to the transient nature of bedload transport in coarse-bed streams and passage of dunes in sand-bed streams. This mean-depth value is referred to as the equilibrium local live-bed pier scour. According to Richardson and Davis (1995, p. 16), the equilibrium local live-bed pier scour is about 10 percent shallower than the maximum-local-pier scour under clear-water conditions. Maximum-local-pier scour may be attained under clearwater conditions before the threshold for incipient motion is reached in the upstream channel and before live-bed scour conditions result in transport of bed material into the scour hole. Exceptionally high flood discharges that induce high bed-material transport upstream from the bridge, therefore, may not produce the deepest scour at a pier. Local pier scour is frequently used to describe scour caused by local hydraulic conditions at the pier, where the effects of any contraction scour, abutment scour, general scour, or long-term scour at the bridge are excluded. Hereinafter, local pier scour is referred to as pier scour.

Clear-water and live-bed distinctions have particular importance in laboratory research where either condition can be maintained throughout the hydraulic experiment. However, these distinctions become less clear under field conditions. During floods, piers in coarse-bed streams can be subjected to clear-water scour at lower flows, live-bed scour at higher flows, and clear-water scour again during the receding flood stages (Mueller, 1996). Furthermore, Mueller (1996) indicated that only a relatively short interval of live-bed scour is needed for pier scour to attain an equilibrium scour depth typical of live-bed conditions. Finally, Mueller and Wagner (2005, p. 19) noted that differences in armoring rates between the upstream channel and the pier-scour hole can complicate scour-hole development, overall scour depth, and the actual condition (clear-water or live-bed). They concluded that the traditional clear-water and live-bed designations are insufficient to fully describe the actual conditions for streams with nonuniform bed material. However, clear-water and live-bed scour designations continue to be important concepts describing the predominant scour condition at a site.

\section{Development of Pier-Scour Equations for Coarse-Bed Streams}

Pier-scour research in the mid-1970s resulted in a pierscour equation, which was recommended by FHWA (Richardson and others, 1975) and widely adopted for conducting pierscour analysis and design in the United States. This equation was largely based on laboratory flume studies with no verification using actual field data. Additional research based on field data in later years indicated that pier scour in nonuniform, coarse, bed material was not well predicted by the recommended equation. The equation has evolved to include correction factors for pier shape, flow alignment, bed-form conditions, and bed-material size and gradation. The latest (2011) version of the equation incorporates a bed-material correction factor $\left(K_{4}\right)$ to compute pier scour in coarse-bed streams.

The pier-scour equation recommended by the FHWA for conducting detailed bridge-scour investigations in the mid1970s was the Colorado State University (CSU) equation (Richardson and others, 1975). A modified version of the CSU equation was later published by FHWA in Hydraulic Engineering Circular No. 18 (HEC-18) (Richardson and others, 1991) and is referred to in this report as the basic HEC-18 equation. The basic HEC-18 equation is:

$$
y_{s}=2.0 y_{o} K_{1} K_{2}\left(\frac{b_{n}}{y_{o}}\right)^{0.65} F_{r}^{0.43},
$$

where

$y_{s} \quad$ is the computed pier-scour depth that assumes the units of $y_{o}$ (in feet for this study);

$K_{1} \quad$ is the correction factor for pier-nose shape, dimensionless;

$K_{2} \quad$ is the correction factor for flow angle of attack on the pier $(\alpha)$, dimensionless; and

$F_{r} \quad$ is the Froude number directly upstream from the pier, dimensionless;

where the Froude number is computed according to:

$$
F_{r}=\frac{V_{o}}{\sqrt{g y_{o}}},
$$

where

$g \quad$ is the acceleration due to gravity, in feet per second squared for this study;

and where all other terms are as previously defined. Further research produced a second version of the basic HEC-18 equation recommended by FHWA (Richardson and others, 1993, p. 39) that included a correction factor $\left(K_{3}\right)$ to account for the bed-form condition (dunes, plane bed, and other variations): 


$$
y_{s}=2.0 y_{o} K_{1} K_{2} K_{3}\left(\frac{b_{n}}{y_{o}}\right)^{0.65} F_{r}^{0.43} \text {, }
$$

where

$$
\begin{gathered}
K_{3} \quad \text { is the correction factor for bed-form } \\
\text { condition, dimensionless; }
\end{gathered}
$$

and where all other terms are as previously defined.

The value of $K_{3}$ is equal to 1.1 for clear-water scour and planebed conditions - typical of coarse-bed streams analyzed in this study. Other values of $K_{3}$ range from 1.1 to 1.2 for beds with medium dunes to 1.3 for beds with large dunes (Richardson and others, 1993, p. 39). These first two versions of the basic HEC-18 equation did not account for bed-material size and gradation effects related to armoring of the streambed.

Most of the pier-scour equations that have been developed were based on laboratory research that used bed material of uniform sand or fine gravel. Consequently, these equations do not adequately describe the effect of bed-material size and gradation on scour depth under actual field conditions. McIntosh (1989) reported that more than 35 equations have been proposed to compute pier scour. Mueller (1996) found that of these 35 equations, only 8 included an explanatory variable (median particle size or $D_{50}$ ) to account for bed-material size.

The effect of nonuniform bed material on scour depth was observed by Shen and others (1966), where the presence of larger particle sizes appeared to reduce scour depth due to armoring. Research by Nicollet and Ramette (1971) compared scour for three separate sand sizes and a sand mixture of equal parts of each size. They concluded that the maximum scour occurred at the critical velocity of each sand size used and that scour depth was less for experiments with the sand mixture. The bed-material gradation coefficient $\left(\sigma_{g}\right)$ was used by Ettema $(1976,1980)$ to show that nonuniform bed material affected the rate of development and final depth of scour under clear-water conditions. These findings were extended to livebed scour conditions by research conducted by Chiew (1984) and Baker (1986). Furthermore, research by Abdou (1993) substantiated that an increase in $\sigma_{g}$ resulted in a decrease in clear-water scour. In all of these studies, findings were based only on laboratory investigations with no validation with field data.

The need to account for bed-material size and gradation effects on pier scour led to research sponsored by FHWA, where laboratory data were used by J. Sterling Jones to develop a correction factor $\left(K_{4}\right)$ that was first presented by Richardson and Davis (1995) and described later by Mueller and Jones (1999). $K_{4}$ accounts for armoring of the scour hole and generally reduces computed scour in coarse-bed materials compared to what would be computed if the factor were not applied.

In response to the work of Jones, the FHWA recommended a new version of the HEC-18 equation for use for both clear-water and live-bed scour conditions that incorporated the $K_{4}$ correction factor (Richardson and Davis, 1995):

$$
y_{s}=2.0 y_{o} K_{1} K_{2} K_{3} K_{4}\left(\frac{b_{n}}{y_{o}}\right)^{0.65} F_{r}^{0.43},
$$

where all terms are as previously defined. Richardson and Davis (1995) defined $K_{4}$ as:

$$
K_{4}=\left[1-0.89\left(1-V_{R}\right)^{2}\right]^{0.5}
$$

where

$$
\begin{aligned}
& V_{R} \quad \text { is the velocity-intensity ratio, dimensionless, } \\
& \text { computed as: }
\end{aligned}
$$

$$
V_{R}=\frac{V_{o}-V_{c 50}^{\prime}}{V_{c 90}-V_{c 50}^{\prime}},
$$

where all other terms are as previously described.

The laboratory research by Molinas and Abdou (1999) and Molinas and Noshi (1999) proposed the following equations for computing $K_{4}$ :

$$
K_{4}=2.0+1.25 \sqrt{\frac{D_{C F}}{D_{50}}}\left(\frac{V_{o}-V_{i m}}{V_{c C F}-V_{i m}}\right)^{0.75} \ln \left(\frac{V_{o}-V_{i m}}{V_{c C F}-V_{i m}}\right),
$$

$D_{C F}$ is the particle size that represents the coarse fraction of the bed material, in feet, computed as:

$$
D_{C F}=\frac{D_{85}+2 D_{90}+2 D_{95}+D_{99}}{6} \text {, }
$$

$V_{i m} \quad$ is the critical velocity that initiates scour of bed material at the pier, and equal to $0.4 V_{c 35}$, in feet per second;

$V_{c C F} \quad$ is the critical velocity for incipient motion of the $D_{C F}$ particle size, in feet per second; and where all other terms are as previously defined.

Mueller (1996) used field data collected by the USGS throughout the United States to develop a $K_{4}$ factor. Partial residual analysis and multiple linear regression were used to identify the important variables affecting pier-scour depth. The investigation showed that the $D_{95}$ particle size was the dominant bed-material variable affecting pier scour under both clear-water and live-bed scour conditions. The $D_{50}$ particle size also was considered important based on Gao and others (1993), where the velocity-intensity ratio based on only the $D_{50}$ particle size was shown to have an influence on pier-scour depth. Critical velocities associated with these two important bed-material variables resulted in the Mueller velocity-intensity ratio ( $V_{R M}$, dimensionless):

$$
V_{R M}=\left(\frac{V_{o}-V_{c 50}^{\prime}}{V_{c 50}-V_{c 95}^{\prime}}\right)
$$

and where all other terms are as previously defined. 
The following equation incorporating the variables that define $V_{R M}$ was then proposed by Mueller (1996) for computing $K_{4}$ :

$$
K_{4}=0.4\left(\frac{V_{o}-V_{c 50}^{\prime}}{V_{c 50}-V_{c 95}^{\prime}}\right)^{0.15},
$$

Equations 10 and 11 apply for the condition when:

$$
0<\left(\frac{V_{o}-V_{i 50}}{V_{c 50}-V_{i 95}}\right)<450 .
$$

In a review of equations describing pier scour, Mueller and Jones (1999) concluded that equations 10-12 proposed by Mueller (1996) for quantifying $K_{4}$ provided the best explanation of the differences between observed and computed pier-scour depth. However, the authors recognized the need that additional field data be obtained and further research be conducted to improve the accuracy of pier-scour equations.

Chase and Holnbeck (2004) compared 42 pier-scour measurements made by the USGS in 5 States at 11 bridge sites with scour depth computed by 5 of the more commonly cited equations. The version of the HEC-18 equation that includes $K_{4}$ as proposed by Mueller (equations 5 and 11) was statistically determined to be the best equation for predicting pier scour in coarse-bed materials for that data set.

Mueller (1996, p. 115) found that the HEC-18 equation (equation 5) underestimated very few instances of observed scour but substantially overestimated observed scour depths because of the restrictions placed on $K_{4}$. When first published as part of the HEC-18 equation (Richardson and Davis, 1995, p. 36), $K_{4}$ could only be applied when the $D_{50}$ bed-material size was greater than or equal to 60 millimeters $(\mathrm{mm})$. Furthermore, the minimum value of $K_{4}$ that could be used in any instance was 0.70 .

The current (2011) HEC-18 equation with $K_{4}$ as recommended by the FHWA still has the form of equation 5, but the Mueller $K_{4}$ is computed by equation 11 for bed-material size conforming to current (2011) HEC-18 criteria (Richardson and Davis, 2001, p. 6.6). The criteria for applying $K_{4}$ require that the $D_{50}$ particle size be greater than or equal to $2 \mathrm{~mm}$ and the $D_{95}$ particle size be greater than or equal to $20 \mathrm{~mm}$. The minimum value of $K_{4}$ under current (2011) criteria is 0.40 .

\section{Recent Research of Pier-Scour Equations}

Pier-scour research has continued and new equations have been proposed that might lead to more reliable scour prediction than currently provided by conventional FHWA and HEC-18 equations. Recent (2003-05) pier-scour research in nonuniform sediment mixtures includes results reported by Molinas (2003) and Mueller and Wagner (2005). Molinas (2003) proposed two new methods that include equations similar in principle to those currently (2011) recommended by FHWA (equations 5 and 11). The first method proposed by Molinas (2003) includes the pier-scour equation:

$$
\frac{y_{s}}{b_{n}^{0.66} y_{o}^{0.17}}=K_{U}^{\prime} K_{1} K_{2} K_{3} K_{4} \psi^{0.55}
$$

where

$$
\begin{array}{cc}
K_{U}^{\prime} & \text { is a constant equal to } 1.21 \text {, in inch-pound } \\
\text { units; }
\end{array}
$$

$$
\psi=\frac{V_{o}-V_{i m}}{V_{c C F}-V_{i m}},
$$

where $0 \leq \psi \leq 1$ (this is the same ratio contained in equation 8); and where all other terms are as previously defined. Also, velocity relations associated with equation 14 are:

$$
V_{c C F}=K_{c} D_{C F}^{1 / 3} y_{o}^{1 / 6},
$$

which is essentially the same as $V_{c i}$ in equation 1 , and

$$
V_{i}=K_{I} D_{35}^{1 / 3} Y^{1 / 6},
$$

which is the same as $V_{i m}$ in equation 8 (where $V_{i m}=0.4 V_{c 35}$ ) where

$$
\begin{aligned}
& K_{c} \quad \text { is a constant equal to } 12.0 \text {, in inch-pound } \\
& \quad \text { units; } \\
& K_{I} \quad \text { is a constant equal to } 4.8 \text {, in inch-pound units. }
\end{aligned}
$$

$K_{4}$ is then given by:

$$
K_{4}=1.25+3 \sqrt{\frac{D_{C F}}{D_{50}}} \psi^{0.60} \ln (\psi+0.5),
$$

for $0.0 \leq K_{4} \leq 1.0$, and $0.0 \leq \psi \leq 1.0$; and where all other terms are as previously defined.

The second method proposed by Molinas (2003) incorporates $K_{4}$ computed by equation 17 into the HEC- 18 equation (equation 5), with the addition of $K_{i}$ given by:

$$
\begin{gathered}
\text { for } V_{o}>V_{i m}, \quad K_{i}=\left(1-\frac{V_{i m}}{V_{o}}\right)^{0.45}, \\
\text { for } V_{o} \leq V_{i m}, \quad K_{i}=0.0,
\end{gathered}
$$

where $K_{i}$ is the correction factor for initiation of motion.

$K_{4}$ from equation 17 and $K_{i}$ factor from equation 18 are incorporated to produce the form of the HEC-18 equation proposed by Molinas (2003):

$$
y_{s}=2.0 y_{o} K_{1} K_{2} K_{3} K_{4} K_{i}\left(\frac{b_{n}}{y_{o}}\right)^{0.65} F_{r}^{0.43},
$$


and where all other terms are as previously defined. The research by Molinas that resulted in equation 19 showed improvements among the laboratory data over the most revised version of the HEC-18 equation (equation 5 with $K_{4}$ by equation 6); however, that research was not supported by field data.

Finally, Mueller and Wagner (2005) used field data from 266 pier-scour measurements in the sand and coarser size range to show that the magnitude of overprediction by the HEC-18 equation without the inclusion of $K_{4}$ increased as the median size of the bed material increased. They proposed the development of a new methodology for determination of $K_{4}$ based on numerous combinations of variables analyzed. The best correlation resulted when $K_{4}$ was related to the pier width and median bed-material size according to:

$$
K_{4}=0.35\left(\frac{b_{n}}{D_{50}}\right)^{0.19},
$$

where all terms are as previously defined. Mueller and Wagner (2005) determined that HEC-18 equation results using $K_{4}$ determined by equation 20 did not perform as well (statistically) as the HEC-18 equation using $K_{4}$ determined by equation 11 proposed by Mueller (1996). Still, the basis for the approach using equation 20 was considered justified because of previous research (Sheppard, 2004) that showed the ratio of pier width to sediment particle size to be an important scour mechanism.

\section{Methods of Data Collection}

Data collected in the field for this study included information needed to measure pier scour along with bed material and ancillary data needed to compute scour using equations like those presented in the "Background" section of this report. Measured pier scour is a scour-depth estimate derived from various hydraulic measurements made at a bridge. Computed scour is a scour-depth prediction derived from variables measured in the field and equations developed in previous studies. During 2001-07, pier-scour and related data were collected at bridges in Montana with a variety of stream sizes, streamflow conditions, pier configurations, and bed-material sizes and gradations.

Limited-detail field procedures were used to investigate pier scour during this study. Measurements made at each site (tables 1,2) included the following:

1. Pier-scour depth derived from cross-section survey data.

2. Bed-material characteristics.

3. Approach velocity $\left(V_{o}\right)$ and approach depth of flow $\left(y_{o}\right)$ at each pier.

4. Water-surface elevation and slope at the bridge during high-flow conditions.

5. Pier geometry and flow angle of attack on the pier $(\alpha)$.
6. Background notes describing site-specific conditions.

Upon returning from the field, equations 1 and 2 were used to compute the critical velocity to initiate scour of bed material at the pier $\left(V_{c 50}^{\prime}\right)$, which was compared to the measured approach velocity $\left(V_{o}\right)$ to determine whether or not a valid real-time pier-scour measurement was obtained for a site. If a valid real-time pier-scour measurement was indicated, the information collected was used to determine measured scour and computed scour using equation 5 . Where measured scour exceeded scour computed by equation 5 , follow up data were collected to help explain the inconsistency. Follow up data-collection efforts included (1) measuring approach depth of flow at different magnitudes of streamflow to confirm the elevation of the reference bed surface (fig. 2), also called the concurrent ambient-bed surface (Landers and Mueller, 1996, p. 36-37; Mueller and Wagner, 2005, p. 8-9); (2) determining the potential effects of the thalweg on scour-depth estimation, (3) identifying the presence of substantial amounts of large, woody debris; (4) collecting additional bed-material samples; and (5) reassessing the flow angle of attack.

\section{Site Selection}

Bridge sites were selected to include a range of coarse bed-material characteristics, bridge-pier configurations, and stream characteristics such as bed-material size and gradation, pier width, and stream size that can affect pier scour. Several bed-material, pier, and site criteria were used to select suitable bridge sites for measurement of pier scour.

Foremost was the bed-material criteria used to select sites. Only sites with noncohesive, nonuniform, coarse-bed material were considered, which is consistent with HEC-18 criteria (Richardson and Davis, 2001), where the $D_{50}$ particle size is $\geq 2 \mathrm{~mm}$ and the $D_{95}$ particle size is $\geq 20 \mathrm{~mm}$. Most of the bridge sites investigated were located in stream reaches that would likely be classified as pool-riffle or plane-bed (Montgomery and Buffington, 1997).

Criteria also were used to determine if piers associated with a site were suitable for scour measurement. When piers are aligned parallel with the flow, maximum scour typically occurs at the upstream nose of the pier (Mueller and Wagner, 2005 , p. 18). Bridge sites selected for measurement had piers with little or no flow angle of attack ( $\alpha$ generally less than about 5 degrees). A few sites where $\alpha$ ranged from 5 to a maximum of 10 degrees were selected because remnant scour holes with no substantial infilling indicated maximum scour depth was located near the upstream nose of the pier, and a few sites also were selected because flow became more aligned with the pier at higher stages of flow. Thus, scour measurements were made at the upstream end of the pier in all instances.

Other criteria also were considered in the selection of sites. Sites selected had no unique hydraulic conditions that could produce pier scour by processes other than those accounted for in the pier-scour equations evaluated in this report. Furthermore, piers that had substantial accumulation 


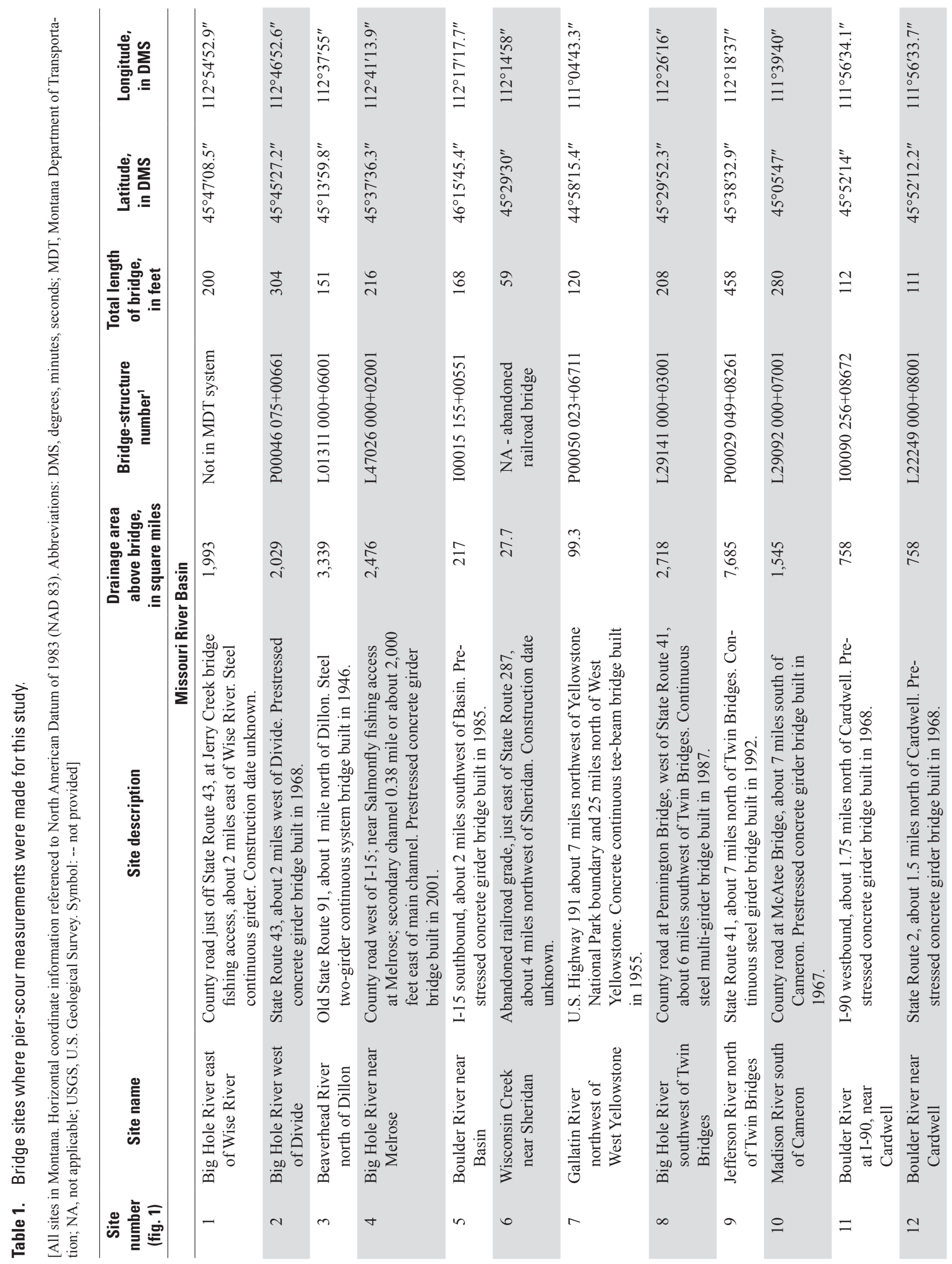




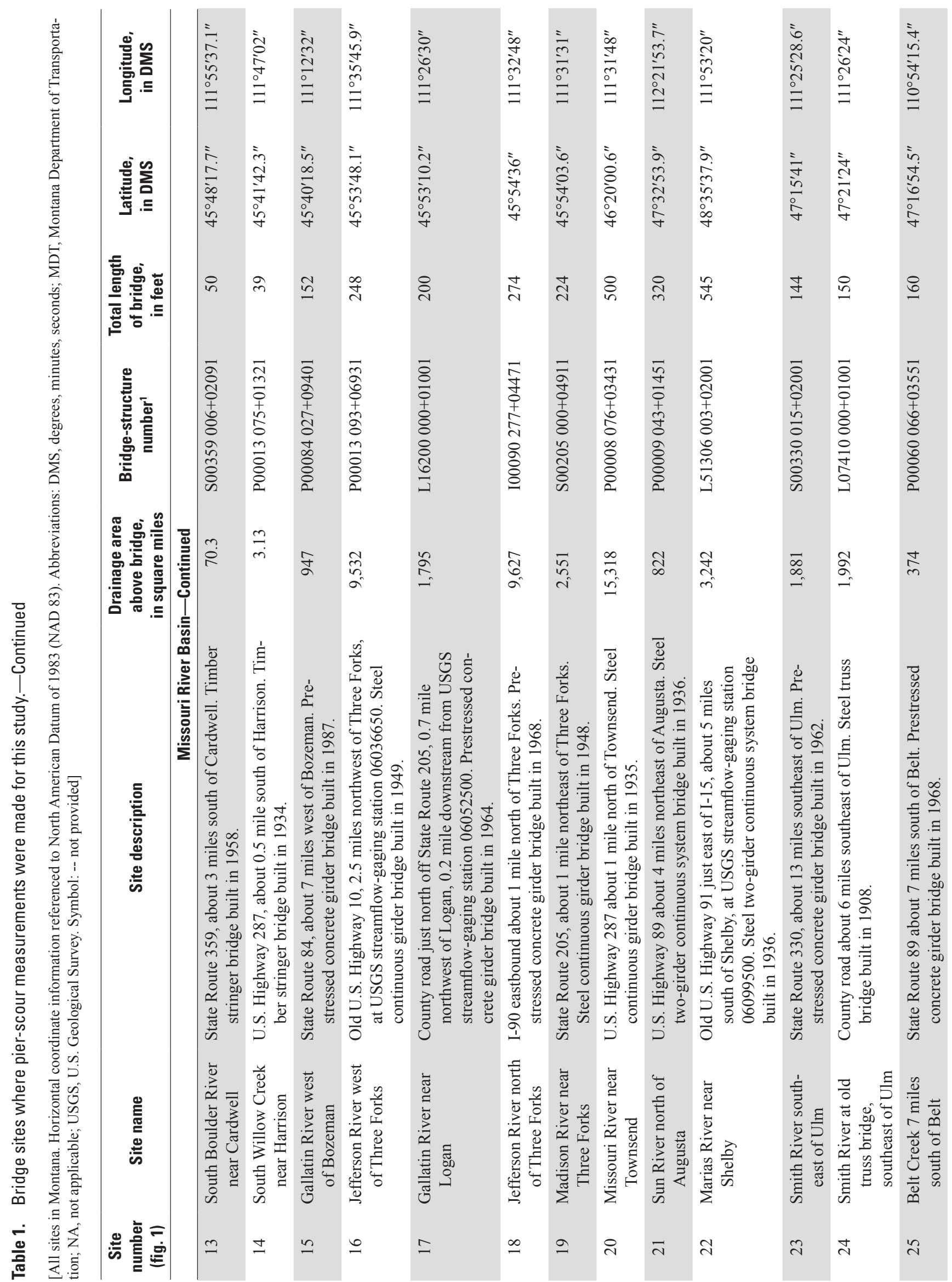




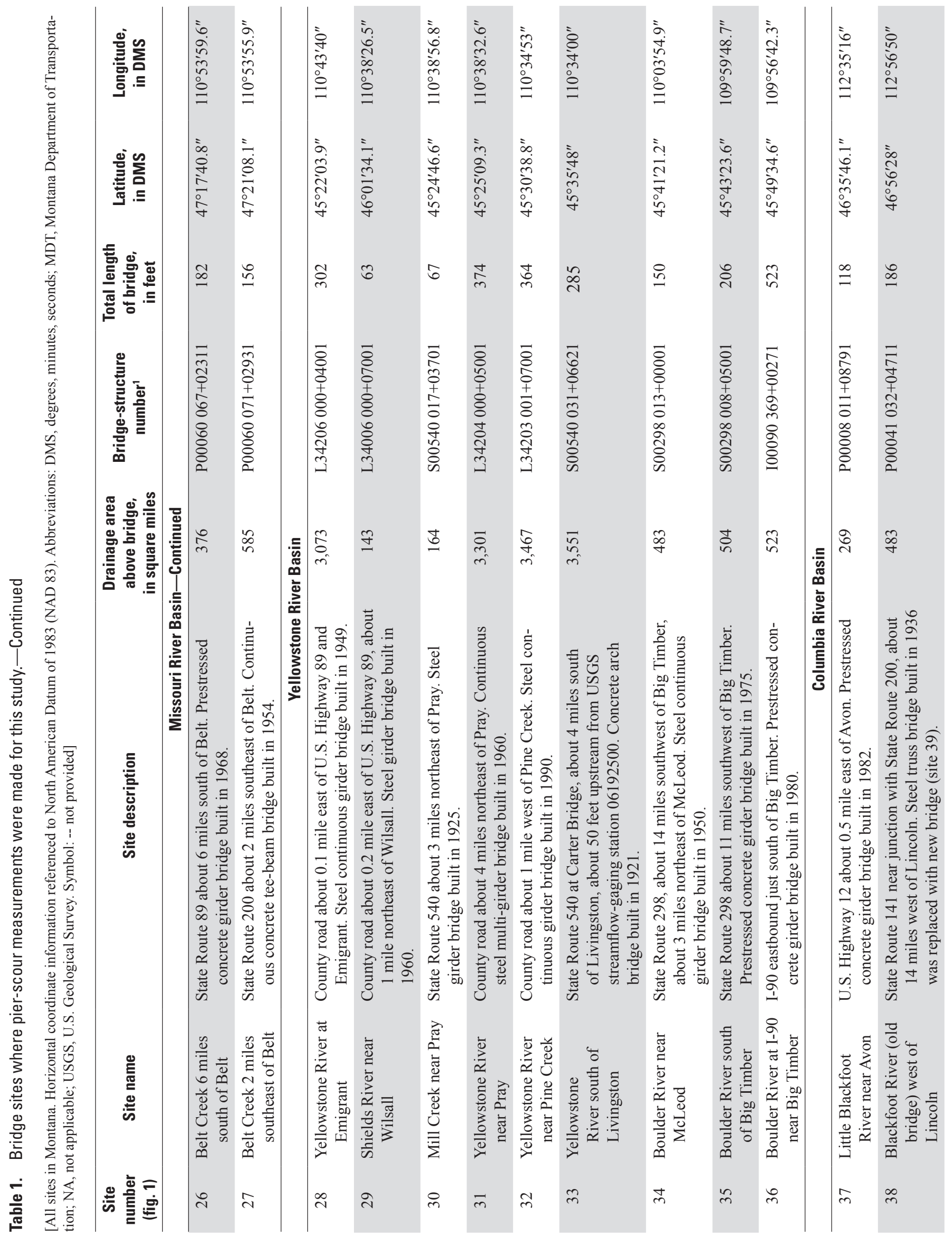




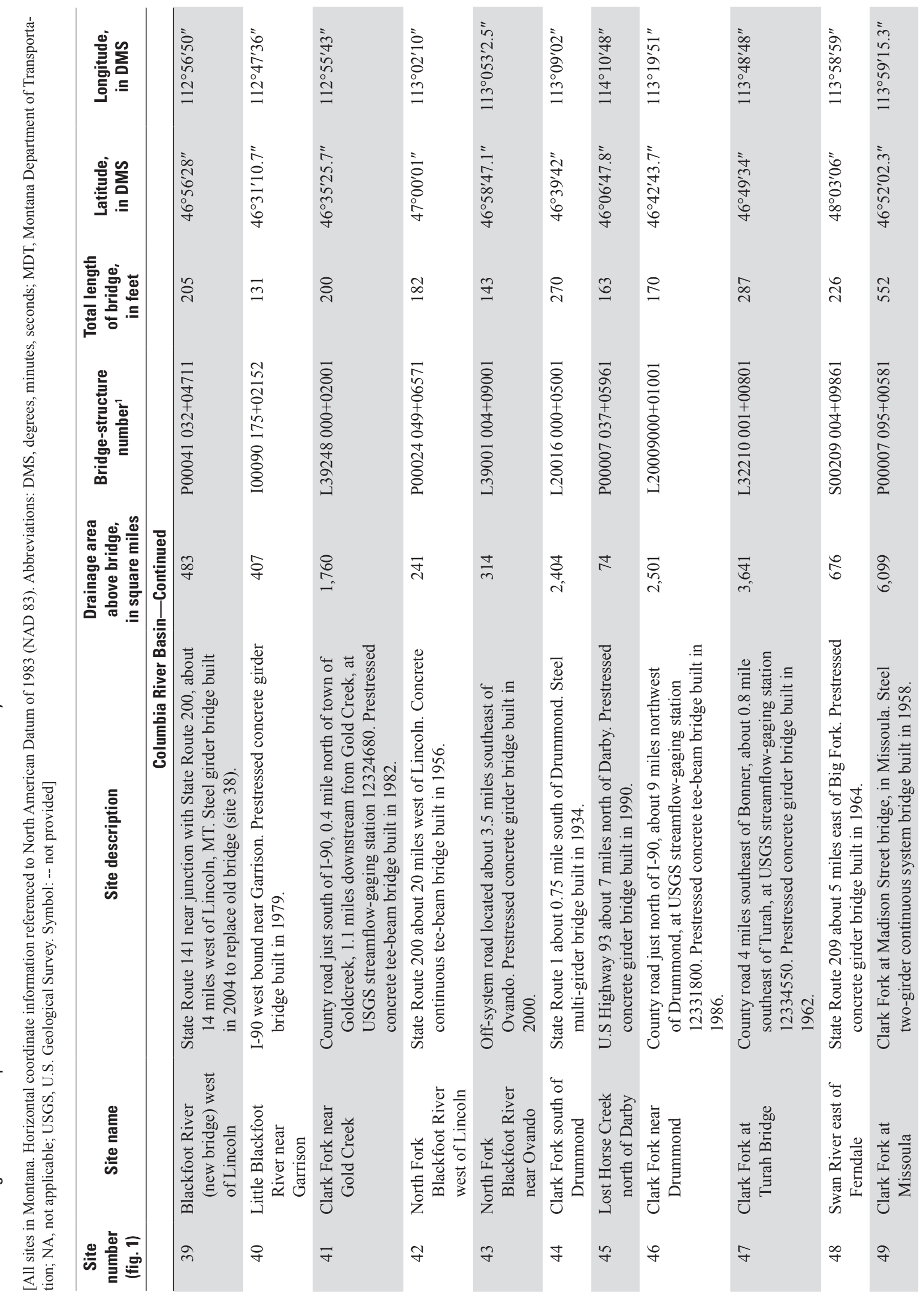




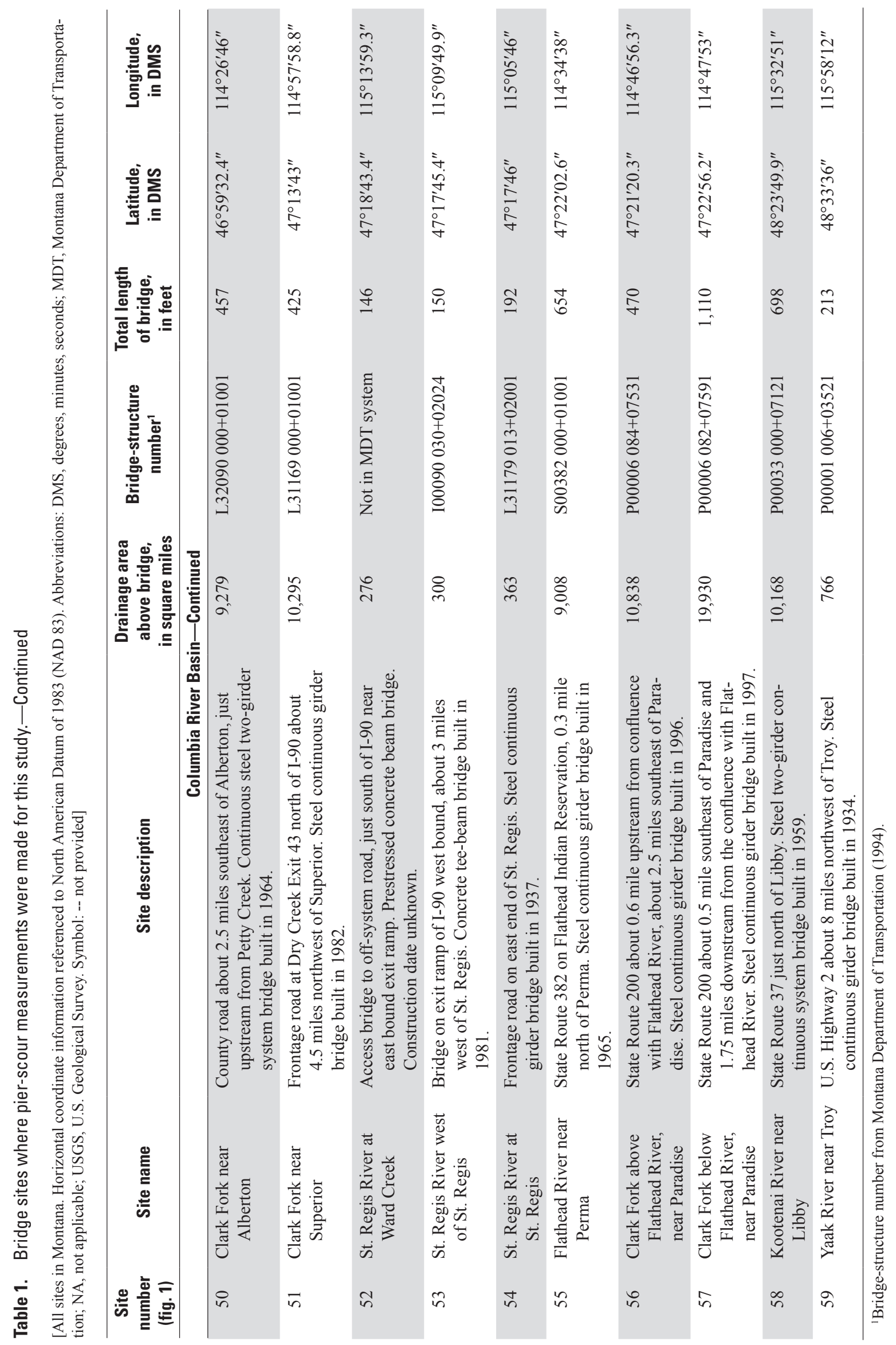


of large, woody debris or a tendency for debris accumulation based on historical information were not considered for scour measurements. Finally, sites were selected where contraction and abutment scour did not contribute to pier scour because (1) all piers were beyond the influence of abutments that may have projected into the main-channel flow, (2) the site had an incised channel with little or no flood plain or lacked any flow contraction at the bridge, (3) bridge abutments did not encroach within the bankfull width of the stream, or (4) runoff conditions at the site were insufficient to cause measurable contraction or abutment scour effects.

\section{Pier-Scour Depth}

Measured pier-scour depth $\left(y_{s}^{\prime}\right)$ is the difference between a measured reference surface of the streambed and the lowest measured location within a pier-scour hole. Scour measurements primarily consist of cross-section surveys, but also may include longitudinal profile surveys and continuous measurement of scour using fixed instrumentation. At all sites, scour measurements were conducted during intermittent site visits using portable instrumentation. At some sites, scour measurements also were made using instrumentation fixed at a particular location (Mueller and Landers, 2000 and Mueller and Wagner, 2005).

Scour measurements obtained during high-flow conditions at each bridge fell into one of four categories:

1. One measurement at a single pier.

2. One measurement at multiple piers.

3. Multiple measurements at a single pier.

4. Multiple measurements at multiple piers.

Most measurements were in category 1 or 2 .

The most common method to measure scour is to conduct cross-section surveys. For this study most crosssection surveys involved sounding with a cable-suspended Columbus-type (or C-type) weight (Jarrett and Boyle, 1986) deployed from the upstream side of the bridge deck. A few scour measurements were obtained by probing the streambed with a graduated metal rod when the bridge deck was close to the streambed surface and the streamflow depth was less than about 3 or $4 \mathrm{ft}$.

In addition to these more-conventional methods, hydroacoustic devices also were used. A portable chartrecording echo sounder was used at several sites to survey cross sections. Two devices used with the echo sounder included a knee board with a transom-mounted transducer fitted through the board and a transducer mounted to the bottom of a Columbus weight (Mueller and Landers, 2000, p. 37-51). The echo sounder and transducer worked well in the stream channel, some distance away from the pier, but scour measurements at piers during high-flow conditions generally were problematic because (1) turbulence and drawdown near the pier made the knee board pitch, heave, or roll, so the transducer was not submerged beneath the water surface or was out of vertical alignment at times; (2) air entrainment interfered with acoustic transmission; or (3) high surface velocities swept the kneeboard away from the pier.

A boat equipped with a portable survey-grade echo sounder and global positioning system (GPS) was used in several of the large, deep rivers during moderate streamflow conditions to obtain channel-bottom data near the pier and longitudinally upstream and downstream from the bridge cross section. These data were used with other high-flow crosssection surveys to assess scour depth and to evaluate remnant scour. The prevalence of clear-water scour conditions resulting in no substantial infilling allowed for measurements of remnant scour that would not have been valid under live-bed conditions. The boat and echo sounder were used at two large river sites exceeding $300 \mathrm{ft}$ in flow width (sites 51 and 57, table 1), where the channel bottom was surveyed for several hundred feet upstream and downstream from the piers to aid in determining the reference bed surface longitudinally. The boat and echo sounder also were used at site 57 to map the pierscour hole, where the flow angle of attack on three out of four piers was 10 degrees. At this site, soundings were conducted at depths in excess of $10 \mathrm{ft}$ along the sides and along the upstream and downstream ends of the piers under moderate streamflow conditions to confirm that the deepest scour was located at the upstream end of the piers.

Fixed instrumentation used to measure scour included acoustic transducers and scour rods installed at 10 sites. Transducers were used at three sites (sites 21, 33, and 41) and consisted of one or more 6-degree beamwidth, 235-kilohertz devices, fastened to the pier near the upstream end to measure scour depth on a near-continuous basis (15-minute time step). Scour rods were used at seven sites (sites 4, 5, 30, 37, 40, 43, and 45) and typically consisted of 3-ft- to 6-ft-long smooth steel rods 1-inch in diameter that were encased most of their lengths in a 2-inch-diameter steel pipe fixed to the pier near the upstream end to measure only maximum scour during spring runoff. Elevations of the top of the rod and casing were surveyed and tied to a local vertical datum before and after runoff and were used with other information to determine scour depth. The top of the scour rod and outer casing projected above the water surface, or the top of casing was sealed to prevent intrusion of sand and finer suspended sediment during submergence. Streambed material supporting scour rods generally exceeded the diameter of the rod. Scour rods were observed in operation during very high approach velocities (velocity at site 45 was $11.1 \mathrm{ft} / \mathrm{s}$, table 2) with no indication of erratic rod movement or vibration that might cause drilling action that would induce additional scour.

Cross sections, piers, and other features were described using a USGS convention, in which features are referenced in a downstream view from left to right. Therefore, the left bank was considered to be on the left-hand side of the observer when looking downstream in the direction of streamflow. The left pier at a site, therefore, was designated pier number 1 and piers to the right were assigned pier numbers 2, 3, and so on. 
Table 2. Pier-scour data collected for this study.

[All pier-scour data are for sites with nonuniform, coarse-bed material (predominantly gravel and cobble). Pier number: 1, 2, 3 are piers left to right looking downstream. The term "single" is used when bridges had one pier. Pier type: S, single; G, group; Debris effects: I, insigificant; M, moderate. Pier-scour depth from field measurements. Abbreviations: $\mathrm{ft}$, feet; $\mathrm{ft} / \mathrm{s}$, feet per second; $\sigma_{g}$, gradation coefficient, dimensionless; mm, millimeters; $D_{i}$, surface bed-material particle size where $i$ percent of particles are finer by weight, in millimeters]

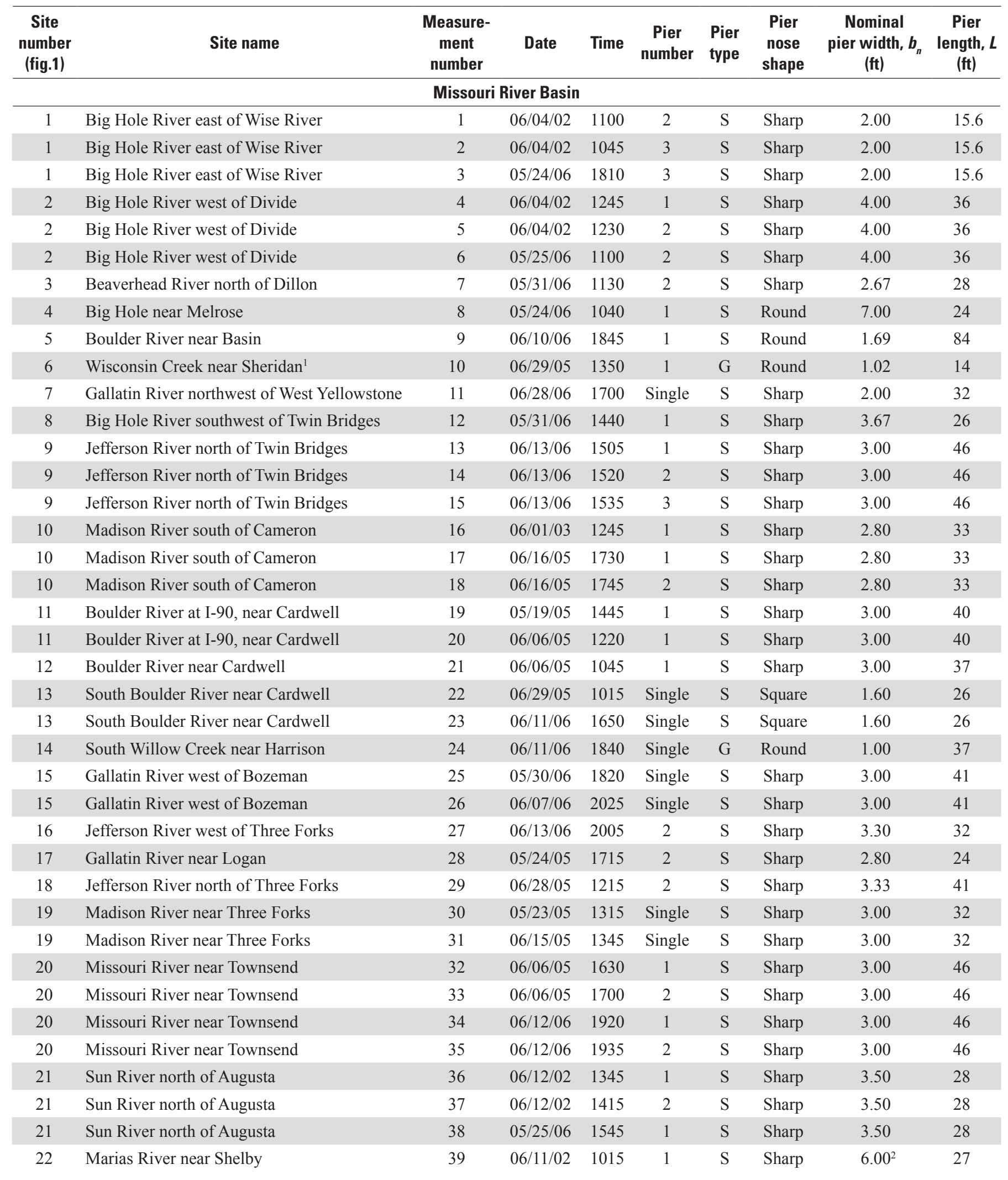




\begin{tabular}{|c|c|c|c|c|c|c|c|c|c|c|}
\hline $\begin{array}{l}\text { Flow angle } \\
\text { of attack, } \alpha \\
\text { (degrees) }\end{array}$ & $\begin{array}{l}\text { Approach } \\
\text { velocity, } V_{o} \\
\text { (ft/s) }\end{array}$ & $\begin{array}{l}\text { Approach depth } \\
\text { of flow, } y_{o} \\
\text { (ft) }\end{array}$ & $\begin{array}{l}\text { Debris } \\
\text { effects }\end{array}$ & $D_{16}$ & $D_{50}$ & $D_{84}$ & $\boldsymbol{D}_{95}$ & $\sigma_{g}$ & $\begin{array}{l}\text { Pier-scour } \\
\text { depth, } y_{s}^{\prime} \\
\text { (ft) }\end{array}$ & $\begin{array}{c}\text { Accuracy } \\
\text { of } y_{s}^{\prime} \\
\text { (ft) }\end{array}$ \\
\hline \multicolumn{11}{|c|}{ Missouri River Basin } \\
\hline 0 & 7.50 & 7.51 & I & 40.5 & 102 & 176 & 263 & 2.09 & 1.14 & 0.30 \\
\hline 0 & 7.89 & 7.41 & I & 40.5 & 102 & 176 & 263 & 2.09 & 1.44 & .30 \\
\hline 0 & 7.79 & 7.09 & I & 40.5 & 102 & 176 & 263 & 2.09 & 1.12 & .30 \\
\hline 0 & 7.21 & 4.94 & I & 23.7 & 71.3 & 155 & 190 & 2.56 & .76 & .30 \\
\hline 0 & 6.65 & 4.76 & I & 23.7 & 71.3 & 155 & 190 & 2.56 & 1.35 & .30 \\
\hline 0 & 3.62 & 1.62 & I & 20.3 & 35.8 & 59.2 & 80.3 & 1.71 & .98 & .30 \\
\hline 0 & 5.15 & 4.10 & I & 28.2 & 59.5 & 104 & 157 & 1.92 & 2.23 & .20 \\
\hline 0 & 4.58 & 5.25 & M & 20.8 & 38.5 & 60.9 & 80.1 & 1.71 & 1.27 & .40 \\
\hline 10 & 5.98 & 7.27 & I & 28.8 & 60.7 & 114 & 148 & 1.99 & 1.35 & .40 \\
\hline 10 & 7.21 & 6.02 & I & 28.8 & 60.7 & 114 & 148 & 1.99 & 2.33 & .30 \\
\hline 8 & 6.80 & 7.83 & I & 28.8 & 60.7 & 114 & 148 & 1.99 & 2.06 & .30 \\
\hline 0 & 5.53 & 3.01 & I & 29.9 & 79.8 & 149 & 253 & 2.23 & .86 & .30 \\
\hline 0 & 5.64 & 3.22 & I & 29.9 & 79.8 & 149 & 253 & 2.23 & .78 & .30 \\
\hline 0 & 6.09 & 3.22 & I & 29.9 & 79.8 & 149 & 253 & 2.23 & .79 & .30 \\
\hline 0 & 4.00 & 4.73 & I & 2.58 & 17.1 & 44.1 & 82.9 & 4.14 & 1.37 & .30 \\
\hline 0 & 5.02 & 5.67 & I & 2.58 & 17.1 & 44.1 & 82.9 & 4.14 & 2.03 & .30 \\
\hline 0 & 6.25 & 15.9 & I & 5.91 & 22.3 & 57.0 & 89.6 & 3.11 & 2.08 & .40 \\
\hline 0 & 6.24 & 5.80 & I & 17.8 & 33.3 & 57.4 & 76.0 & 1.80 & 1.70 & .30 \\
\hline 0 & 3.87 & 8.47 & I & 8.85 & 19.1 & 31.1 & 47.5 & 1.87 & .90 & .30 \\
\hline 0 & 4.67 & 2.73 & I & 19.7 & 29.8 & 43.2 & 56.8 & 1.48 & 1.47 & .20 \\
\hline 0 & 5.22 & 1.76 & I & 19.7 & 29.8 & 43.2 & 56.8 & 1.48 & 1.10 & .20 \\
\hline 0 & 5.83 & 8.47 & I & 11.9 & 29.7 & 64.1 & 87.4 & 2.32 & 1.23 & .50 \\
\hline 0 & 4.74 & 8.18 & M & 11.9 & 29.7 & 64.1 & 87.4 & 2.32 & 1.43 & .50 \\
\hline 0 & 7.84 & 10.3 & I & 11.9 & 29.7 & 64.1 & 87.4 & 2.32 & 2.19 & .50 \\
\hline 0 & 6.83 & 10.0 & M & 11.9 & 29.7 & 64.1 & 87.4 & 2.32 & 2.99 & .50 \\
\hline 0 & 5.74 & 3.60 & I & 26.8 & 57.4 & 111 & 156 & 2.03 & 1.50 & .20 \\
\hline 0 & 4.77 & 2.83 & I & 26.8 & 57.4 & 111 & 156 & 2.03 & 1.17 & .20 \\
\hline 0 & 5.18 & 3.12 & I & 26.8 & 57.4 & 111 & 156 & 2.03 & 1.38 & .20 \\
\hline 0 & 9.56 & 14.7 & I & 7.36 & 22.7 & 44.0 & 59.3 & 2.44 & 2.97 & .50 \\
\hline
\end{tabular}


Table 2. Pier-scour data collected for this study.-Continued

[All pier-scour data are for sites with nonuniform, coarse-bed material (predominantly gravel and cobble). Pier number: 1, 2, 3 are piers left to right looking downstream. The term "single" is used when bridges had one pier. Pier type: S, single; G, group; Debris effects: I, insigificant; M, moderate. Pier-scour depth from field measurements. Abbreviations: $\mathrm{ft}$, feet; ft/s, feet per second; $\sigma_{g}$, gradation coefficient, dimensionless; mm, millimeters; $D_{i}$, surface bed-material particle size where $i$ percent of particles are finer by weight, in millimeters]

\begin{tabular}{|c|c|c|c|c|c|c|c|c|c|}
\hline $\begin{array}{c}\text { Site } \\
\text { number } \\
\text { (fig.1) }\end{array}$ & Site name & $\begin{array}{c}\text { Measure- } \\
\text { ment } \\
\text { number }\end{array}$ & Date & Time & $\begin{array}{c}\text { Pier } \\
\text { number }\end{array}$ & $\begin{array}{l}\text { Pier } \\
\text { type }\end{array}$ & $\begin{array}{c}\text { Pier } \\
\text { nose } \\
\text { shape }\end{array}$ & $\begin{array}{c}\text { Nominal } \\
\text { pier width, } b_{n} \\
\text { (ft) }\end{array}$ & $\begin{array}{c}\text { Pier } \\
\text { length, } L \\
\text { (ft) }\end{array}$ \\
\hline \multicolumn{10}{|c|}{ Missouri River Basin-Continued } \\
\hline 23 & Smith River southeast of Ulm & 40 & $06 / 08 / 05$ & 0820 & 1 & $\mathrm{~S}$ & Sharp & 3.20 & 31 \\
\hline 23 & Smith River southeast of Ulm & 41 & $06 / 14 / 05$ & 1115 & 1 & $\mathrm{~S}$ & Sharp & 3.20 & 31 \\
\hline 24 & $\begin{array}{l}\text { Smith River at old truss bridge, southeast of } \\
\text { Ulm }\end{array}$ & 42 & $06 / 08 / 05$ & 1415 & 2 & $\mathrm{~S}$ & Round & 3.53 & 16 \\
\hline 25 & Belt Creek 7 miles south of Belt & 43 & $06 / 13 / 05$ & 1330 & 1 & $\mathrm{~S}$ & Sharp & 3.50 & 42.5 \\
\hline 26 & Belt Creek 6 miles south of Belt & 44 & $06 / 10 / 05$ & 1445 & 1 & $\mathrm{~S}$ & Sharp & 3.50 & 42.5 \\
\hline 27 & Belt Creek 2 miles southeast of Belt & 45 & $06 / 13 / 05$ & 1430 & Single & $\mathrm{S}$ & Sharp & 2.00 & 33.5 \\
\hline \multicolumn{10}{|c|}{ Yellowstone River Basin } \\
\hline 30 & Mill Creek near Pray & 49 & $06 / 14 / 06$ & 1600 & Single & $\mathrm{S}$ & Square & 2.00 & 21 \\
\hline 31 & Yellowstone River near Pray & 50 & $06 / 23 / 05$ & 1000 & 1 & $\mathrm{~S}$ & Sharp & 3.00 & 27 \\
\hline 31 & Yellowstone River near Pray & 51 & $06 / 23 / 05$ & 0930 & 3 & $\mathrm{~S}$ & Sharp & 3.00 & 27 \\
\hline 31 & Yellowstone River near Pray & 52 & $06 / 08 / 06$ & 1400 & 1 & $\mathrm{~S}$ & Sharp & 3.00 & 27 \\
\hline 31 & Yellowstone River near Pray & 53 & $06 / 08 / 06$ & 1420 & 3 & $\mathrm{~S}$ & Sharp & 3.00 & 27 \\
\hline 32 & Yellowstone River near Pine Creek & 54 & $06 / 05 / 02$ & 1145 & 1 & $\mathrm{~S}$ & Round & 3.50 & 26 \\
\hline 32 & Yellowstone River near Pine Creek & 55 & $06 / 05 / 02$ & 1230 & 2 & $\mathrm{~S}$ & Round & 3.50 & 26 \\
\hline 33 & Yellowstone River south of Livingston & 56 & $06 / 10 / 06$ & 1445 & 1 & $\mathrm{~S}$ & Round & 10.0 & 25 \\
\hline 33 & Yellowstone River south of Livingston & 57 & $06 / 14 / 06$ & 1145 & 2 & $\mathrm{~S}$ & Round & 10.0 & 25 \\
\hline 37 & Little Blackfoot River near Avon & 63 & $06 / 08 / 07$ & 1100 & 1 & G & Round & 1.69 & 46 \\
\hline 38 & Blackfoot River (old bridge) west of Lincoln & 64 & $06 / 10 / 02$ & 1215 & Single & $\mathrm{S}$ & Sharp & 3.00 & 21 \\
\hline 38 & Blackfoot River (old bridge) west of Lincoln & 65 & $06 / 19 / 02$ & 1445 & Single & $\mathrm{S}$ & Sharp & 3.00 & 21 \\
\hline 39 & Blackfoot River (new bridge) west of Lincoln & 66 & $05 / 13 / 05$ & 1745 & Single & $\mathrm{S}$ & Sharp & 2.00 & 42 \\
\hline 39 & Blackfoot River (new bridge) west of Lincoln & 67 & $06 / 05 / 06$ & 1845 & Single & $\mathrm{S}$ & Sharp & 2.00 & 42 \\
\hline 39 & Blackfoot River (new bridge) west of Lincoln & 68 & $06 / 08 / 07$ & 1745 & Single & $\mathrm{S}$ & Sharp & 2.00 & 42 \\
\hline 40 & Little Blackfoot River near Garrison & 69 & $06 / 11 / 06$ & 1330 & Single & $\mathrm{S}$ & Sharp & 2.00 & 46 \\
\hline 40 & Little Blackfoot River near Garrison & 70 & 06/08/07 & 1320 & Single & $\mathrm{S}$ & Sharp & 2.00 & 46 \\
\hline 41 & Clark Fork near Gold Creek & 71 & $06 / 07 / 07$ & 0745 & 2 & $\mathrm{~S}$ & Round & 5.00 & 31 \\
\hline 42 & North Fork Blackfoot River west of Lincoln & 72 & $05 / 30 / 02$ & 1115 & 1 & $\mathrm{~S}$ & Sharp & 3.00 & 42 \\
\hline 42 & North Fork Blackfoot River west of Lincoln & 73 & $05 / 30 / 02$ & 1130 & 2 & $\mathrm{~S}$ & Sharp & 3.00 & 42 \\
\hline 42 & North Fork Blackfoot River west of Lincoln & 74 & $05 / 17 / 05$ & 1400 & 2 & $\mathrm{~S}$ & Sharp & 3.00 & 42 \\
\hline 43 & North Fork Blackfoot River near Ovando & 75 & $05 / 20 / 05$ & 1330 & 1 & G & Round & 1.69 & 34 \\
\hline
\end{tabular}




\begin{tabular}{|c|c|c|c|c|c|c|c|c|c|c|}
\hline $\begin{array}{c}\text { Flow angle } \\
\text { of attack, } \alpha \\
\text { (degrees) }\end{array}$ & $\begin{array}{c}\text { Approach } \\
\text { velocity, } V_{o} \\
\text { (ft/s) }\end{array}$ & $\begin{array}{c}\text { Approach depth } \\
\text { of flow, } y_{o} \\
\text { (ft) }\end{array}$ & $\begin{array}{l}\text { Debris } \\
\text { effects }\end{array}$ & $D_{16}$ & $D_{50}$ & $D_{84}$ & $D_{95}$ & $\sigma_{g}$ & $\begin{array}{l}\text { Pier-scour } \\
\text { depth, } y_{s}^{\prime} \\
\text { (ft) }\end{array}$ & $\begin{array}{c}\text { Accuracy } \\
\text { of } y_{s}^{\prime} \\
\text { (ft) }\end{array}$ \\
\hline \multicolumn{11}{|c|}{ Missouri River Basin-Continued } \\
\hline 5 & 6.18 & 5.08 & $\mathrm{I}$ & 6.67 & 13.6 & 26.7 & 41.5 & 2.00 & 2.92 & 0.30 \\
\hline 5 & 5.89 & 4.57 & I & 6.67 & 13.6 & 26.7 & 41.5 & 2.00 & 2.24 & .30 \\
\hline 0 & 6.59 & 7.88 & $\mathrm{I}$ & 19.8 & 39.2 & 86.0 & 123 & 2.08 & .85 & .30 \\
\hline 0 & 5.97 & 6.88 & M & 15.1 & 44.6 & 88.8 & 125 & 2.42 & 2.13 & .30 \\
\hline 0 & 6.45 & 2.80 & I & 14.5 & 38.0 & 75.1 & 105 & 2.28 & 1.85 & .50 \\
\hline 0 & 6.11 & 2.86 & I & 23.1 & 39.5 & 76.3 & 109 & 1.82 & 1.14 & .20 \\
\hline \multicolumn{11}{|c|}{ Yellowstone River Basin } \\
\hline 0 & 5.73 & 2.12 & I & 32.2 & 67.4 & 130 & 164 & 2.01 & .53 & .20 \\
\hline 0 & 6.48 & 6.32 & I & 41.5 & 92.1 & 133 & 165 & 1.79 & 1.67 & .30 \\
\hline 0 & 7.61 & 8.97 & M & 41.5 & 92.1 & 133 & 165 & 1.79 & 1.40 & .40 \\
\hline 0 & 6.66 & 7.10 & I & 41.5 & 92.1 & 133 & 165 & 1.79 & 1.20 & .30 \\
\hline 0 & 8.13 & 9.77 & $\mathrm{M}$ & 41.5 & 92.1 & 133 & 165 & 1.79 & 1.63 & .40 \\
\hline 0 & 6.85 & 10.3 & M & 10.9 & 54.5 & 114 & 174 & 3.23 & 2.95 & .50 \\
\hline 0 & 8.25 & 11.5 & I & 10.9 & 54.5 & 114 & 174 & 3.23 & 3.05 & .40 \\
\hline 0 & 10.5 & 8.75 & I & 24.1 & 55.5 & 88.8 & 117 & 1.92 & 6.60 & .20 \\
\hline 0 & 5.44 & 6.00 & I & 24.1 & 55.5 & 88.8 & 117 & 1.92 & 3.13 & .40 \\
\hline 0 & 5.06 & 3.18 & I & 13.2 & 29.2 & 55.2 & 77.9 & 2.06 & 1.47 & .20 \\
\hline 0 & 3.03 & 7.80 & I & 1.68 & 9.63 & 26.8 & 38.2 & 4.00 & 1.00 & .30 \\
\hline 0 & 3.12 & 8.60 & I & 1.68 & 9.63 & 26.8 & 38.2 & 4.00 & 1.41 & .30 \\
\hline 0 & 3.04 & 5.24 & I & 1.68 & 9.63 & 26.8 & 38.2 & 4.00 & .76 & .30 \\
\hline 0 & 3.78 & 4.76 & I & 1.68 & 9.63 & 26.8 & 38.2 & 4.00 & .84 & .30 \\
\hline 0 & 4.08 & 5.04 & I & 1.68 & 9.63 & 26.8 & 38.2 & 4.00 & 1.16 & .30 \\
\hline 0 & 4.87 & 2.41 & I & 14.6 & 57.4 & 98.1 & 127 & 2.59 & .60 & .20 \\
\hline 0 & 5.98 & 2.70 & I & 14.6 & 57.4 & 98.1 & 127 & 2.59 & .75 & .20 \\
\hline 0 & 4.22 & 5.58 & I & 8.62 & 30.9 & 79.8 & 159 & 3.04 & 2.09 & .20 \\
\hline 0 & 6.77 & 3.94 & I & 22.4 & 36.6 & 60.6 & 82.2 & 1.65 & 1.46 & .20 \\
\hline 0 & 8.30 & 3.98 & I & 22.4 & 36.6 & 60.6 & 82.2 & 1.65 & 1.71 & .30 \\
\hline 0 & 5.81 & 2.84 & I & 22.4 & 36.6 & 60.6 & 82.2 & 1.65 & .56 & .30 \\
\hline 0 & 5.33 & 2.06 & I & 25.9 & 50.1 & 93.7 & 128 & 1.90 & .45 & .20 \\
\hline
\end{tabular}


Table 2. Pier-scour data collected for this study.-Continued

[All pier-scour data are for sites with nonuniform, coarse-bed material (predominantly gravel and cobble). Pier number: 1, 2, 3 are piers left to right looking downstream. The term "single" is used when bridges had one pier. Pier type: S, single; G, group; Debris effects: I, insigificant; M, moderate. Pier-scour depth from field measurements. Abbreviations: $\mathrm{ft}$, feet; $\mathrm{ft} / \mathrm{s}$, feet per second; $\sigma_{g}$, gradation coefficient, dimensionless; mm, millimeters; $D_{i}$, surface bed-material particle size where $i$ percent of particles are finer by weight, in millimeters]

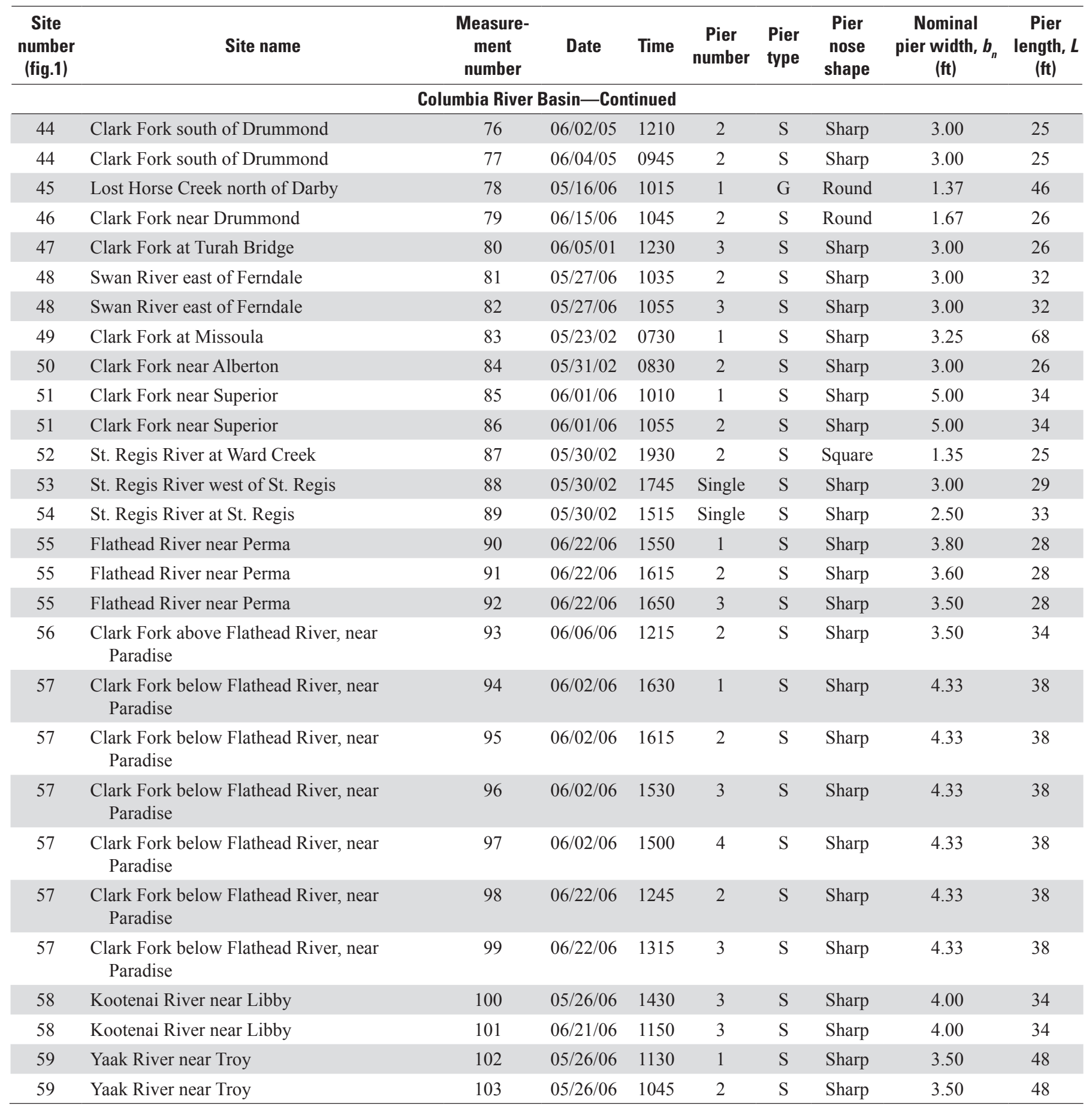

${ }^{1}$ Site is abandoned railroad bridge on abandoned railroad grade.

${ }^{2}$ Pier width based on exposed footing width of $6 \mathrm{ft}$. 


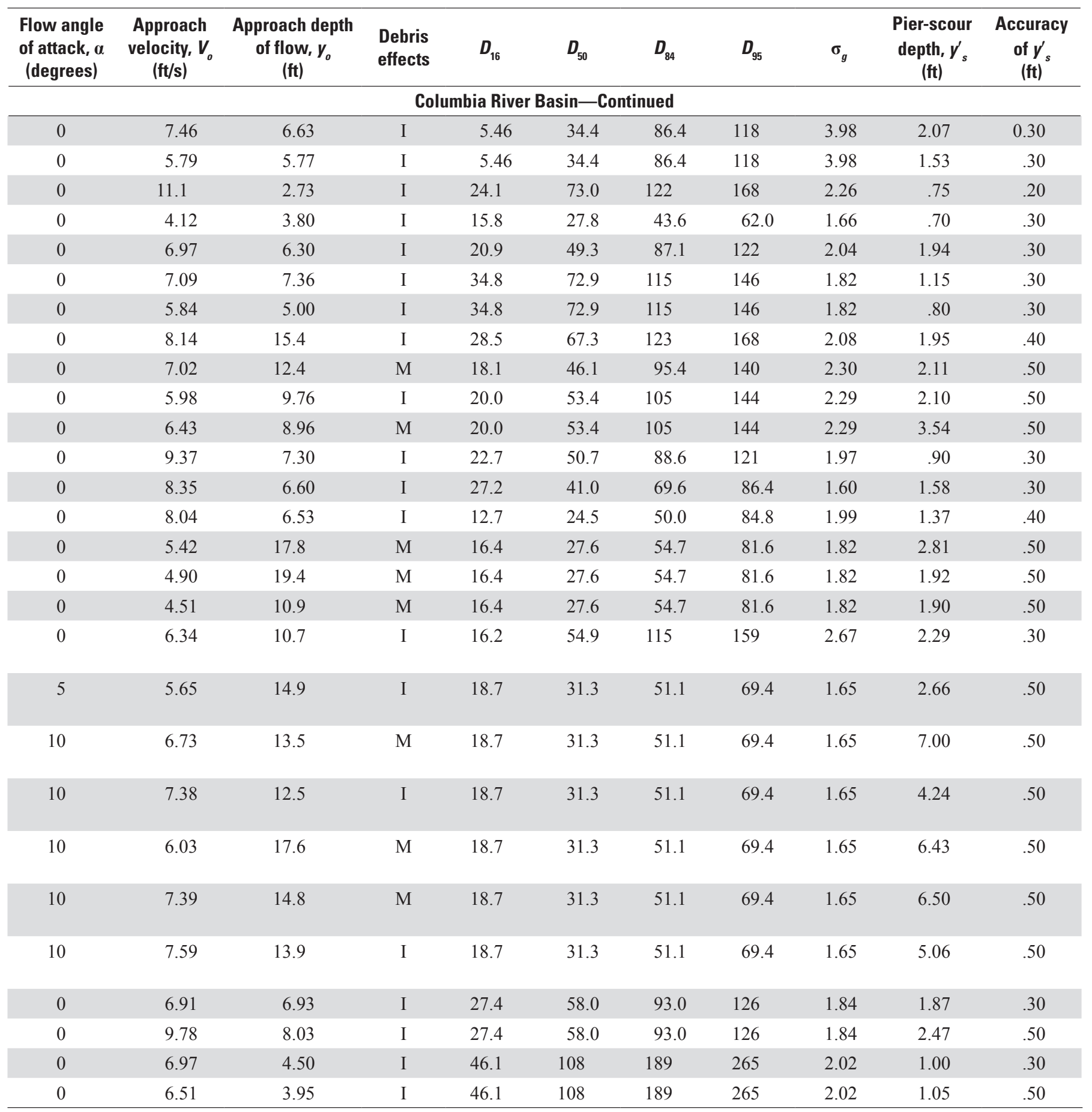


The pier-numbering system used in the study differs from MDT pier numbers indicated on design drawings because bents or abutments at each end of the bridge structure included in the MDT pier-numbering system were excluded from the USGS pier-numbering system. The USGS pier-numbering system also was applied to sites operated and maintained by county and local entities that frequently had no engineering drawings with pier-numbering information.

Cross-section data were used to determine the reference bed surface (fig. 2) from which the lowest measured elevation of the scour hole was subtracted to determine measured or observed scour. The reference bed surface was sketched (Mueller and Wagner, 2005, p. 8) using cross-section data obtained during high-flow conditions and used to determine pier-scour depth (fig. 3). Surveys to establish the reference bed surface mostly were made along the upstream bridge face by using a manually operated four-wheel-base bridge crane and B-reel setup with a cable-suspended sounding weight deployed from the bridge deck (Rantz and others, 1982; Turnipseed and Sauer, 2010). Cross-section surveys varied in detail; complete cross sections were surveyed at a majority of sites. At a few sites, cross-section data were only obtained close to the pier, but far enough away (laterally) from the pier to accurately define the reference bed surface (figs. 2 and 3). In all instances, detailed soundings were conducted near the pier to define the scour hole. Measurements occasionally were obtained longitudinally along the streambed for some distance upstream and downstream along the major axis of the pier to help define the reference bed surface.
Surveys at most bridges were conducted on at least two separate dates - once during high-flow conditions (typically in May or June) to obtain pier-scour measurements, and once during low flow to assess channel-geometry changes, if any, attributed to general scour (Richardson and Davis, 2001, p. 5.1-5.18) or channel deposition relative to the high-flow measurement. Additionally, low-flow measurements were analyzed in combination with high-flow measurements to detect the extent of scour-hole infilling, to indicate whether clearwater or live-bed scour conditions prevailed at a site, and to assess the relative channel stability at the bridge cross section over a range of flow conditions.

Whether the total clear-water scour for a particular measurement resulted from a single scour event or multiple scour events was not addressed in this study. Cross-section measurements made during low-flow periods indicated remnant scour holes at most sites, so the total scour depth measured under high-flow conditions at a site could be the result of a single scour event or multiple scour events perhaps over consecutive below-average runoff years. As with similar studies using limited-detail field procedures to measure pier-scour depth, the assumption was made that scour depth produced by a single clear-water scour event could be the same as scour depth produced by multiple clear-water events of similar flow magnitude. Therefore, pier-scour depths reported in this study were attributed to high-flow conditions of similar magnitude leading up to and during the time scour measurements were made.

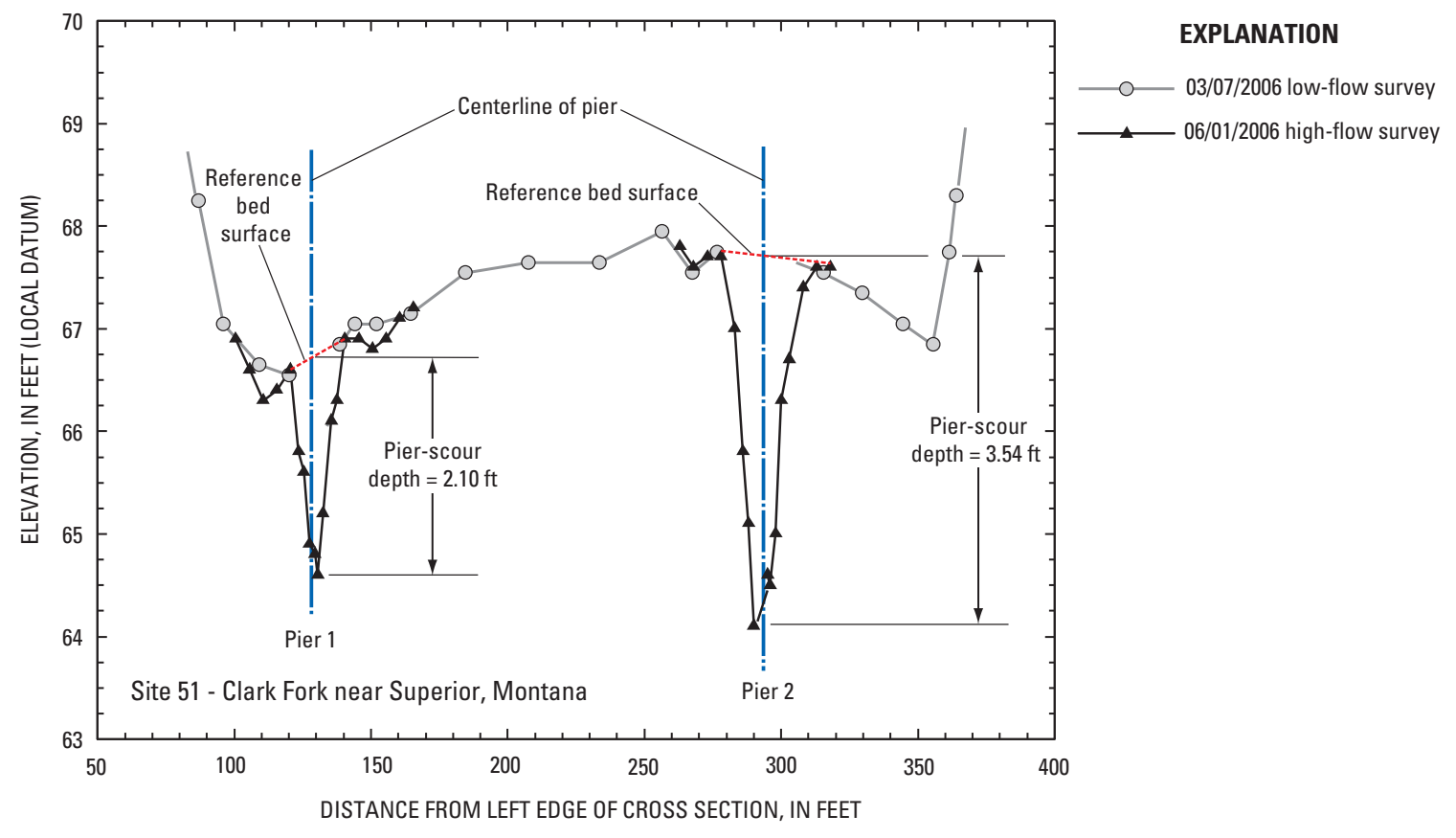

Figure 3. Surveyed cross section at upstream side of bridge showing pier-scour holes and reference bed surface used to determine pier-scour depth. 


\section{Bed-Material Characteristics}

Bed-material sizes used in scour-prediction equations were determined from the surface bed material that generally reflected the armor layer. The potential interaction between the surface and shallow-subsurface bed-material layers (fig. 4) with respect to pier scour and armoring also was of interest for this study. Therefore, shallow-subsurface bed material was sampled and data were compared to surface bed-material data for each site. Surface and shallow-subsurface bed-material measurements were obtained by pebble counts and sieve analyses. Bed-material data were used to construct particlesize distribution curves, which were used to conduct various coarse-bed pier-scour analyses.

Bed material was sampled at each site to characterize the average streambed material near the bridge, with an emphasis on the channel area leading into the bridge opening. Field observations indicated that coarse bed-material particle size and gradation varied at least as much vertically as areally near the bridge. Thus, surface bed-material samples were collected and analyzed to define bed-material characteristics in the same manner as traditional pier-scour studies. However, subsurface bed material typically was sampled at relatively shallow depths less than $1 \mathrm{ft}$ beneath the streambed surface. Both samples generally were collected before or after the runoff season to more easily access and visually inspect the main-channel streambed. Samples were collected with square-hole templates and sieves to define the intermediate or b-axis (Bunte and Abt, 2001, p. 20-27).

The surface layer of the bed material was sampled by pebble counts (Wolman, 1954) where material was predominantly fine gravel and coarser particles $(4 \mathrm{~mm}$ and larger, table 3), and samples were sieved when the composition included sand and very fine gravel. Particles were measured in the field by pebble counts using the US SAH-97 gravelometer developed by the Federal Interagency Sedimentation Project (FISP) and described by Davis (2005). Pebble counts typically were limited to a single sample set of at least 100 particles obtained near the bridge opening. Although only a single sample was obtained, considerable time was spent determining the optimal location to be sampled near the bridge. Samples were collected from the streambed in the main channel whenever possible. Locations were avoided where loose deposits of sediment or the presence of finer material might indicate greater sediment mobility than was likely for the average bed-material composition. For flood-bar deposits, the mid-bar region was sampled thus avoiding the coarser and finer material typically deposited at the upstream and downstream ends of the bar (respectively). Multiple sets of pebble counts were conducted for about 10 percent of the bridge sites (table 4) used in the study. Some variation in particle size between the datasets at each site is indicated (standard deviation for $D_{i}$, table 4), but the relative magnitude of each standard deviation is small in most instances when compared to the corresponding mean particle size at each percentile $\left(D_{i}\right)$ shown.
Shallow-subsurface bed material was sampled within the zone typically considered part of the active layer or the upper layer of the streambed susceptible to sediment transport depending on hydraulic conditions (Molinas, 2000, p. 33-37). Shallow-subsurface bed material was excavated by first removing the surface material or armor layer. Overall depth of excavation from which the subsurface sample was collected was either equal to at least two times the $D_{90}$ particle size, which generally describes the active-layer depth in coarse-bed streams (DeVries, 2002) or was about an 8- to 10 -inch minimum depth (whichever was greater). Bed material representative of the overall streambed was sampled whenever possible. Some samples were obtained along channel fringes or flood bars where the composition appeared similar to bed material located farther out in the stream, but where the combined effects of flow depth and velocity prevented sampling. A single sampling location typically was chosen, with other locations excavated and visually inspected to gain an indication of average composition of the subsurface material. At a few sites, surface material was removed by merely scraping the surface material out of the way by hand. The majority of sites, however, required the use of a shovel to pry and excavate subsurface material. Many sites required the use of both a shovel and pry bar to obtain the sample.

Surface material samples were used to characterize the subsurface material at four sites (site 31 , site 37 , site 38 , and site 39; table 1) where excavation indicated that the size and gradation of the two layers were similar. Shallow-subsurface samples were sieved because sediment could not be characterized by pebble counts alone. Sieved samples were air dried for several weeks or longer, hand sieved using standard 8-inchdiameter metal sieves for 11 screen sizes ranging from 2 to $128 \mathrm{~mm}$, and weighed. Samples were analyzed at the USGS Montana Water Science Center office in Helena, Mont (Guy, 1969). Particle-size distribution curves were determined for the surface- and shallow-subsurface layers of each sample, and important bed-material size percentiles were interpolated from the curves. Percentiles included the $D_{16}, D_{35}, D_{50}, D_{84,} D_{85}, D_{90}$, $D_{95}$, and $D_{99}$ particle sizes, where the subscript $i$ denotes the percentage of material finer (by weight) than the indicated particle size $(D)$. The $D_{50}$ and $D_{95}$ particle sizes were used to test the sensitivity of scour computations to vertical differences in bed-material size and to investigate how possible interactions between surface and shallow-subsurface streambed material are related to pier scour.

Although the gradation and stratification of coarse streambed material can vary (Bunte and Abt, 2001, p. 129), all but three sites where pier-scour data were collected for this study had a higher fraction of coarse material on the surface than in the shallow subsurface. Such conditions are typical of armored streambeds, where enough coarse particles can accumulate to shield the entire bed surface (Lagasse and others, 1991, p. 78-79). Although general channel stability was indicated by clear-water conditions and bed armoring upstream from the bridge at most sites, shallow-subsurface bed material was exposed at the piers when local scour took place. 

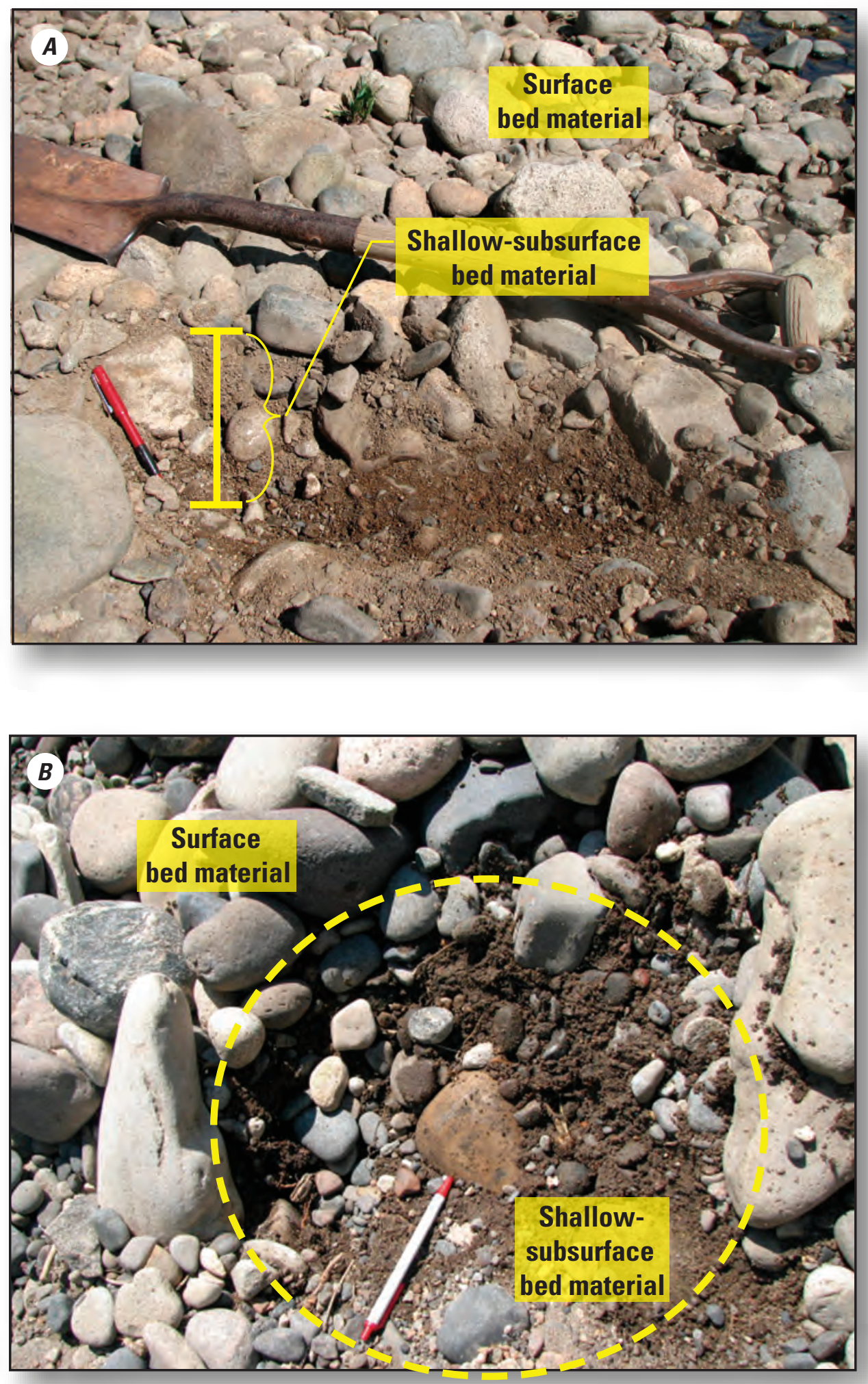

Figure 4. Examples of differences in surface and shallow-subsurface bed material at sites where pier-scour measurements were collected for this study. $A$, Near-vertical perspective of the bed-material variation at site 15 (Gallatin River west of Bozeman). B, Plan view of bedmaterial variation at site 36 (Boulder River at I-90 near Big Timber). 
Table 3. Bed-material size classification used for this study (modified from Lane and others, 1947).

[Symbols: $\geq$, greater than or equal to; $<$, less than]

\begin{tabular}{ll}
\hline $\begin{array}{l}\text { Particle-size range, } \\
\text { in millimeters }\end{array}$ & Classification \\
\hline$\geq 256$ & Boulders. \\
128 to $<256$ & Large cobbles. \\
64 to $<128$ & Small cobbles. \\
32 to $<64$ & Very coarse gravel. \\
16 to $<32$ & Coarse gravel. \\
8 to $<16$ & Medium gravel. \\
4 to $<8$ & Fine gravel. \\
2 to $<4$ & Very fine gravel. \\
0.062 to $<2$ & Very fine to very coarse sand. \\
$<0.062$ & Silt and clay. \\
\hline
\end{tabular}

The shallow subsurface layer may, therefore, be important in determining appropriate bed-material variables to be used in the scour equations and was investigated accordingly.

Based on the $D_{50}$ particle size at each site, a Shields parameter $(\theta)$ equal to 0.047 (Meyer-Peter and Müller, 1948; Gessler, 1971) was used with equations 1 and 2. This value is consistent with a recent study (Mueller and others, 2005), in which a median value of $\theta$ equal to 0.040 was reported for 45 gravel-bed streams and rivers.

\section{Ancillary Data}

Other data also were collected that were necessary to determine measured pier-scour depth and to compute scour. These data included approach velocity $\left(V_{o}\right)$ and approach depth of flow $\left(y_{o}\right)$ for all sites, water-surface elevation and slope, pier geometry, and flow angle of attack on the pier $(\alpha)$. Most of the ancillary data were collected during site visits, but some data at sites with fixed instrumentation were measured continuously.

Approach velocity ideally represents the velocity just upstream from a pier, beyond the extent of the pier-scour hole and flow-acceleration zone (fig. 2). In the field, approach velocity typically is measured from a bridge deck during highflow conditions. A vertical-axis mechanical current meter and USGS standard streamgaging procedures (Rantz and others, 1982 ; Turnipseed and Sauer, 2010) were used to measure the velocity on either side of the piers. Velocity measurements adjacent to piers but outside the scour hole were made to approximate the velocity just upstream from the pier where velocity was difficult to measure. Approach velocity measurements made using a current meter were checked at one site (site 55, table 1) using a portable acoustic Doppler current profiler (ADCP). The specific ways in which approach velocity was determined varied with the method used to measure pier scour at a site.
At sites where pier scour was measured using crosssection surveys during high-flow conditions, approach velocities were measured during the same site visit. Velocity was measured at several locations on either side of a pier to determine the approach velocity reported for the study. Multiple measurements of velocity were made to describe the variability of the approach velocities and any anomalies at a particular location.

At sites where pier scour was measured with scour rods, approach velocities were determined using stage-velocity rating curves. At these sites, approach velocity and associated water stage were measured from the bridge deck during periodic site visits that included a range of moderate- to high-flow conditions. This limited number of measurements was used to develop a stage-velocity rating curve. The maximum seasonal water stage surveyed at the bridge, based on high-water marks, was then used in the stage-velocity rating curve to estimate maximum approach velocity by rating-curve extension. This method is consistent with findings that indicate maximum scour depth is closely correlated with maximum approach velocity (Müeller, 1996, p. 91).

At sites where pier scour was measured with acoustic transducers mounted to piers, approach velocities were determined based on periodic measurements of velocity, continuous measurement of stage, and development of stage-velocity rating curves. The recorded water stage at the bridge corresponding to maximum scour determined from transducer soundings was used with the stage-velocity rating curve to estimate, by rating-curve extension, approach velocity associated with maximum pier scour.

Approach depth of flow ideally represents the depth to stream bottom just upstream from the pier beyond the extent of the pier-scour hole and flow-acceleration zone (fig. 2). In the field, approach depth of flow typically is measured by sounding from a bridge deck during high-flow conditions. Bottom depth was sounded at several locations on either side of a pier to determine the approach depth of flow reported for the study. Multiple measurements of depth were made to describe the variability of the approach depth of flow and any anomalies at a particular location. Bottom depth was referenced to a water-surface elevation to determine the approach depth of flow. For high-flow scour measurements using crosssection surveys, the referenced water-surface elevation was the stage noted on the day and time when the bottom depth was sounded. For sites where pier scour was measured with scour rods, the referenced water-surface elevation was the maximum stage based on high-water marks surveyed after runoff. For sites where pier scour was measured with acoustic transducers, the referenced water-surface elevation was the recorded stage at the time that maximum scour was indicated by the transducer.

Water-surface elevation and slope during soundings were surveyed by trigonometric leveling with a total station and prism (Ghilani and Wolf, 2008) or by measuring from a reference mark down to the water surface. Vertical control for elevations and water-surface elevation measurements were 
Table 4. Variation in surface bed-material particle size for multiple pebble counts made at bridge sites where pier-scour measurements were made for this study.

[Abbreviations: $D_{i}$, surface bed-material particle size where $i$ percent of particles are finer by weight; mm, millimeters; $n=$, number of pebble counts in the dataset. Symbols: $\sigma_{g}$, gradation coefficient]

\begin{tabular}{|c|c|c|c|c|c|c|c|c|}
\hline \multicolumn{3}{|c|}{$\begin{array}{c}\text { Site } 1 \\
n=3\end{array}$} & \multicolumn{3}{|c|}{$\begin{array}{c}\text { Site } 15 \\
n=3\end{array}$} & \multicolumn{3}{|c|}{$\begin{array}{c}\text { Site } 17 \\
n=3\end{array}$} \\
\hline $\begin{array}{c}\text { Particle } \\
\text { size }\end{array}$ & $\begin{array}{l}\text { Mean value } \\
\text { for } D_{i^{\prime}} \\
\text { in } \mathrm{mm}\end{array}$ & $\begin{array}{c}\text { Standard } \\
\text { deviation for } D_{i} \text {, } \\
\text { in } \mathrm{mm}\end{array}$ & $\begin{array}{c}\text { Particle } \\
\text { size }\end{array}$ & $\begin{array}{c}\text { Mean value } \\
\text { for } D_{i} \\
\text { in } \mathrm{mm}\end{array}$ & $\begin{array}{c}\text { Standard } \\
\text { deviation for } D_{i} \text {, } \\
\text { in } \mathrm{mm}\end{array}$ & $\begin{array}{l}\text { Particle } \\
\text { size }\end{array}$ & $\begin{array}{c}\text { Mean value } \\
\text { for } D_{i} \\
\text { in } \mathrm{mm}\end{array}$ & $\begin{array}{c}\text { Standard } \\
\text { deviation for } D_{i^{\prime}} \\
\text { in } \mathrm{mm}\end{array}$ \\
\hline$D_{16}$ & 41 & 3.4 & $D_{16}$ & 46 & 4.8 & $D_{16}$ & 18 & 0.7 \\
\hline$D_{35}$ & 73 & 6.8 & $D_{35}$ & 58 & 3.0 & $D_{35}$ & 27 & 1.3 \\
\hline$D_{84}$ & 176 & 15 & $D_{84}$ & 109 & 19 & $D_{84}$ & 57 & 2.4 \\
\hline$D_{85}$ & 179 & 14 & $D_{85}$ & 112 & 19 & $D_{85}$ & 58 & 2.5 \\
\hline$D_{90}$ & 209 & 8.4 & $D_{90}$ & 127 & 22 & $D_{90}$ & 64 & 3.9 \\
\hline$D_{95}$ & 263 & 4.9 & $D_{95}$ & 143 & 24 & $D_{95}$ & 76 & 12 \\
\hline \multicolumn{3}{|c|}{$\begin{array}{c}\text { Site } 28 \\
n=4\end{array}$} & \multicolumn{3}{|c|}{$\begin{array}{c}\text { Site } 36 \\
n=3\end{array}$} & \multicolumn{3}{|c|}{$\begin{array}{c}\text { Site } 51 \\
n=3\end{array}$} \\
\hline $\begin{array}{l}\text { Particle } \\
\text { size }\end{array}$ & $\begin{array}{l}\text { Mean value } \\
\text { for } D_{i^{\prime}} \\
\text { in } \mathrm{mm}\end{array}$ & $\begin{array}{c}\text { Standard } \\
\text { deviation for } D_{i} \text {, } \\
\text { in } \mathrm{mm}\end{array}$ & $\begin{array}{c}\text { Particle } \\
\text { size }\end{array}$ & $\begin{array}{l}\text { Mean value } \\
\text { for } D_{i} \\
\text { in } \mathrm{mm}\end{array}$ & $\begin{array}{c}\text { Standard } \\
\text { deviation for } D_{i^{\prime}} \\
\text { in } \mathrm{mm}\end{array}$ & $\begin{array}{l}\text { Particle } \\
\text { size }\end{array}$ & $\begin{array}{l}\text { Mean value } \\
\text { for } D_{i} \\
\text { in } \mathrm{mm}\end{array}$ & $\begin{array}{c}\text { Standard } \\
\text { deviation for } D_{i^{\prime}} \\
\text { in } \mathrm{mm}\end{array}$ \\
\hline$D_{16}$ & 15 & 3.0 & $D_{16}$ & 47 & 18 & $D_{16}$ & 20 & 4.0 \\
\hline$D_{35}$ & 25 & 2.9 & $D_{35}$ & 68 & 17 & $D_{35}$ & 37 & 5.8 \\
\hline$D_{50}$ & 33 & 4.7 & $D_{50}$ & 85 & 15 & $D_{50}$ & 53 & 5.1 \\
\hline$D_{84}$ & 68 & 21 & $D_{84}$ & 136 & 8.7 & $D_{84}$ & 105 & 4.1 \\
\hline
\end{tabular}

referenced to a local arbitrary datum at some sites, whereas bench marks and other USGS gage reference marks were used where available. Water-surface slope is not an explanatory variable typically used in scour-prediction equations, but is needed to compute the shear stress on the streambed and to establish initial boundary conditions for site-specific hydraulic modeling studies. Therefore, water-surface slope was surveyed when the high-flow scour measurements were made to enable future research.

Pier geometry was measured or obtained from engineering drawings, and flow angle of attack on the pier $(\alpha)$ was determined visually in the field. The shape of the pier nose was recorded. At sites with tapered piers, nominal pier width $\left(b_{n}\right)$ was computed as the average width in contact with flow at each surveyed water-surface elevation or measured stage. The flow angle of attack on the pier was determined during highflow measurements. At some sites, the flow angle of attack also was assessed during low-flow conditions by observing the relative symmetry of the scour hole and the relative alignment of sediment deposited alongside and downstream from a pier.

Relative pier scour $\left(y_{s}^{\prime} / b\right)$ and relative bed-material size $\left(b / D_{50}\right)$ were calculated for each measurement and used to relate measured pier-scour depth $\left(y_{s}^{\prime}\right)$, effective pier width $(b)$, and median bed-material size $\left(D_{50}\right)$. These variables normalize the data and provide dimensionless plots that indicate a relation with pier-scour depth. Relative pier scour for study data 
was computed by using the effective pier width $(b)$ according to:

$$
b=b_{n} \cos \alpha+L \sin \alpha,
$$

where

$$
\begin{aligned}
& L \quad \text { is the length of the pier measured } \\
& \text { perpendicular to the nominal pier width } \\
& \left(L \geq b_{n}\right) \text {, in feet; } \\
& \alpha \quad \text { is the flow angle of attack on the pier, in } \\
& \text { degrees; }
\end{aligned}
$$

and where all other terms are as previously defined. The effective pier-width adjustment (where $b>b_{n}$, when $\alpha>0$ degrees) accounts for increased scour when flow is not parallel to the major axis of the pier.

Collection of limited-detail measurements included recording background field notes and documenting hydraulic and scour conditions at each site. Typical observations included weather conditions, streamflow conditions, extent of any woody debris accumulated on piers, description of remnant scour holes, and bed-material characteristics and bed form in the stream reach near the bridge. For example, the bed-form correction factor $\left(K_{3}\right)$ was assigned a value of 1.1 for all measurements, based in part on the coarse-bed material and plane-bed conditions recorded in the field. The quality rating of velocity measurements and soundings also was often described, for later use in assessing the suitability of measurements for determination of approach velocity and approach depth of flow.

Water temperature can affect sediment transport and was therefore determined. Water temperature was either measured during a scour measurement with a calibrated thermometer, or estimated by analyzing real-time water temperature records reported for USGS streamflow-gaging stations near the measurement site. Based on an analysis of site measurements and water temperature records, water temperature was estimated to average about $50^{\circ} \mathrm{F}$ over the runoff periods for all sites.

\section{Pier Scour in Coarse-Bed Streams in Montana}

A total of 103 pier-scour measurements were made at 59 bridges on coarse-bed streams in Montana during 2001-07 for this study. Runoff conditions during the study mostly were limited to bankfull discharge approximating the 1.5- to 2-year recurrence-interval flood, which have a 67- and 50-percent chance, respectively, of happening in any year. Data collected for this study were compared to BSDMS scour measurements for coarse-bed streams and envelope curves based on previous studies (Ettema, 1980; Melville, 1984; Chiew, 1984; and Mueller and Wagner, 2005). Data from this study also were compared with selected historical pier-scour measurements from Montana associated with peak streamflows of greater recurrence interval (up to about 100 years) than pier-scour measurements collected for this study. Surface and shallowsubsurface bed-material data were collected for each site where pier-scour measurements were made to characterize the particle size and gradation. Bed-material characteristics in the two layers were used to compute scour by using the current (2011) version of the HEC-18 equation (equation 5), and the computed scour was compared to the measured scour. Relations between surface and shallow-subsurface bed-material characteristics and pier scour also were analyzed.

\section{Hydrologic and Hydraulic Conditions}

Seasonal runoff in the mountain and foothill regions of the western one-half of Montana (fig. 1) typically results from spring snowmelt supplemented with May and June rainfall. In that region, summary data (McCarthy, 2005) indicate that runoff can begin in April, typically peaks in May or June, and recedes through the summer months to base-flow conditions in the fall. Isolated thunderstorms and broader-based general storms can cause occasional periods of high flow with varying durations in the summer and fall. Streamflow conditions during this study generally were below average for the three major river basins in the study. Maximum daily mean flow during the spring runoff seasons was generally below average, and spring-runoff volumes were below to near average (http://waterdata.usgs.gov/mt/nwis). Annual flood-frequency data (Parrett and Johnson, 2004) indicate that instantaneous peak discharges at most gaging stations near bridge sites where scour was measured approximated the 1.5- to 2-year recurrence interval during 2001-07 runoff. Lawlor (2004) found that the recurrence interval for bankfull discharge at 41 streams in western Montana generally ranged from 1.0 to 4.4 years with a median value of 1.5 years. Stream velocities and seasonal high-water marks measured at some ungaged sites in smaller drainage basins indicated that more intense runoff conditions, and hence, higher recurrence-interval peak streamflows occurred in these smaller basins compared to peak flows in larger drainage basins. Despite general below-average runoff conditions during this study, streamflow at most sites probably reached bankfull to near-bankfull conditions, which can produce notable sediment transport (Andrews, 1983) and scour. For example, the rate of increase in bedload discharge, based on 1999-2001 data at one study site (site 32, fig. 1 and table 1), increased as streamflow approached bankfull discharge and then bedload discharge diminished beyond the bankfull stage (Holnbeck, 2005, p. 12-16). Real-time pier scour recorded at a downstream site (site 33, fig. 1 and table 1) by a fixed acoustic transducer between May-June 2006 was closely linked to changes in streamflow (fig. 5) for flows up to bankfull. The response of scour-hole depth to changes in streamflow at this site is complicated, however, by the sediment supply from upstream that also increases during higher streamflows. For example, the scour hole is shown to be infilling (fig. 5) at times during the rising limb in early June, 
Figure 5. Pier-scour depth and streamflow measured at site 33, Yellowstone River south of Livingston, Montana (station 06192500), May and June, 2006.

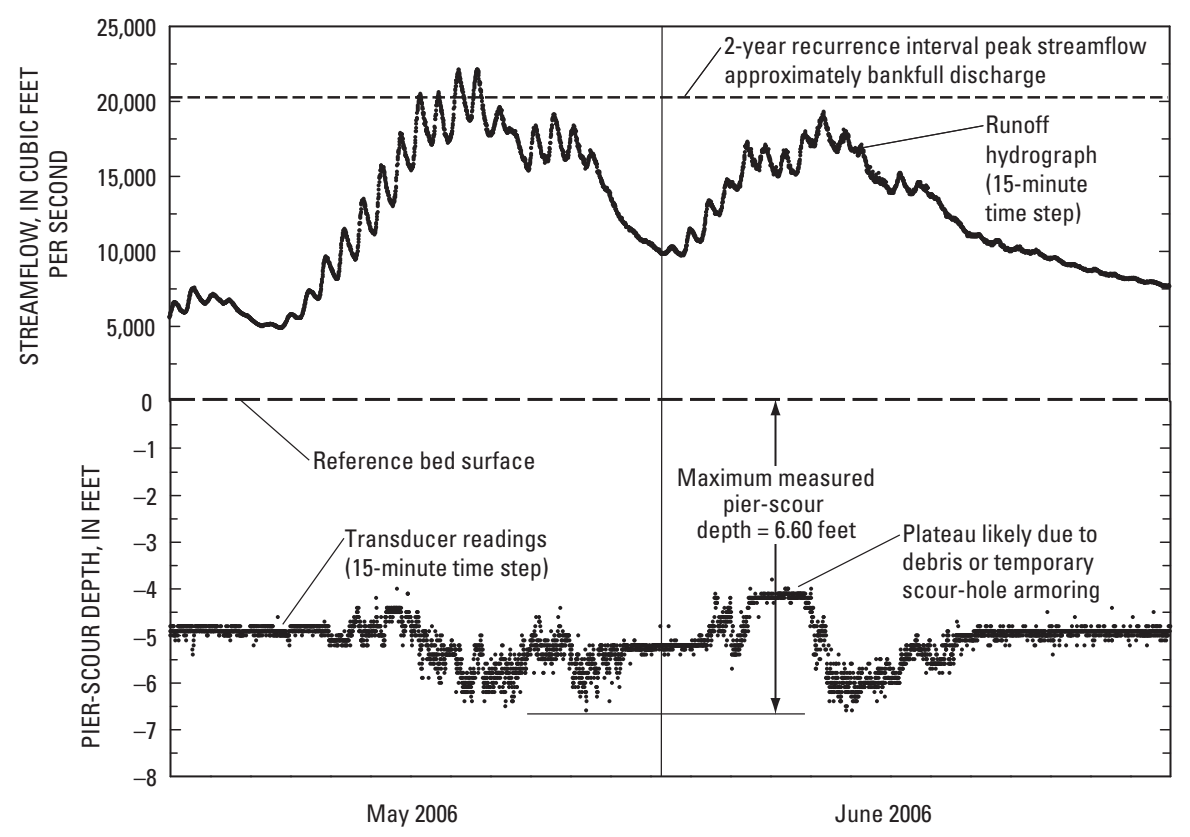

most likely as a result of bedload transport from upstream. The plateau that persisted for 3 days in early June (fig. 5) likely is due to woody debris deposited in the scour hole and later dislodged or to temporary armoring when small cobbles that can be transported (Holnbeck, 2005, p. 8-20) partially infilled the scour hole. Transducers at three other sites recorded similar responses of scour to changes in streamflow during the study period.

The persistence of below- to near-average streamflow conditions during the study period likely produced repeated clear-water scour conditions at most study sites over successive years. Therefore, infilling of scour holes from one runoff season to the next was probably minimal or only partial, allowing for the continued scouring of holes during successive clear-water periods. Overall, runoff conditions during the study probably limited the opportunities to measure maximum scour, but sites where measurements were successfully made reflect real-time scour conditions at piers in coarse-bed streams.

\section{Scour Data Collected}

Pier-scour measurements were made on various dates at 59 bridge sites on coarse-bed streams. Of those measurements, 103 satisfied criteria requiring the measured approach velocity $\left(V_{o}\right.$, table 2) exceed the critical velocity $\left(V_{c 50}^{\prime}\right)$ to initiate scour of bed material at the piers. Incipient motion computations based on the $D_{50}$ particle size indicated that 96 out of 103 pierscour measurements were made under clear-water scour conditions. Two of the measurements were made under hydraulic conditions of supercritical flow, one measurement was made at or very near critical flow, and 100 measurements were made under subcritical flow. Comparisons of cross-section data obtained during high-flow measurements with pre- or postrunoff cross-section data generally indicated a lack of substantial scour-hole infilling, which also supports the conclusion that clear-water conditions prevailed. Of the measurements made, 50 percent had an approach velocity $\left(V_{o}\right)$ that equaled or exceeded 70 percent of the critical velocity $\left(V_{c 50}\right)$ for incipient motion of bed material upstream from the bridge, which might indicate that scour was measured very near the threshold between clear-water and live-bed scour $\left(V_{o} / V_{c 50}=1.00\right)$ where maximum pier scour was shown in laboratory studies (Chiew, 1984; Melville, 1984).

The pier and stream characteristics associated with the 103 measurements made for this study were variable but some general observations can be made about the measurements based on the individual measurements and summary statistics (tables 2 and 5). Despite reasonably high approach velocities, measured pier scour was less than a couple of feet in depth for 70 percent of the measurements made at the coarsebed sites. Particle size of sampled surface bed material was predominantly very coarse gravel based on the $D_{50}$ particle size. Surface bed material at one-half of the sites lacked substantial gradation, as indicated by gradation coefficients less than about 2.0. Drainage areas for most sites ranged from a few hundred square miles to a few thousand square miles in drainage area. About 60 percent of the sites were located on high-gradient streams based on water-surface slopes that exceeded 0.002 (Jarrett, 1984). The approach depth of flow typically was less than twice the effective pier width. This condition is probably common in high-gradient streams in the northern Rocky Mountains where flow depths tend to be shallower compared to flatter-gradient streams having similar streamflow magnitudes and bridge pier widths. There were no instances where pier-scour measurements involving relatively 
shallow approach flow depths in relation to effective pier width required later adjustment of computed pier-scour depth for wide-pier effect (Richardson and Davis, 2001, p. 6.7). All sites were subjected to hydraulic conditions where real-time scour was in progress at the time of measurement, as indicated by relative velocities $\left(V_{o} / V_{c 50}^{\prime}\right)$ in excess of 1.00 (table 5). Maximum relative pier scour from this study is less than values associated with previously published envelope curves, and therefore, data from this study do not redefine the upper magnitude of those envelope-curve relations.

The effects of high-flow duration on pier scour were not investigated because most scour data for a site were collected in a single day. Continuous scour measurements made at three sites using fixed acoustic transducers, however, indicated that scour typically increased as streamflow increased. Pier scour at site 33 , with a 10 -ft wide pier (fig. 5, table 2), included remnant scour of about $5 \mathrm{ft}$, with scour depth fluctuating from a minimum of about $4 \mathrm{ft}$ (some infilling) to a maximum of about $6.6 \mathrm{ft}$. Maximum pier scour at this site was attained for hydraulic conditions near the threshold between clear-water and live-bed scour $\left(V_{o} / V_{c 50}=1.05\right)$. Transducer soundings indicate that a similar magnitude of maximum pier scour (about $6.6 \mathrm{ft}$ ) was attained several times during May-June 2006 (fig. 5) when flows ranged from less than to slightly greater than bankfull discharge. These continuous data from the transducers provide some insight on the site-specific effects of high-flow duration on pier scour.

The effective pier-width adjustment for flow angle of attack (equation 21) was made for 11 of the 103 scour measurements. The adjustment was applied when $\alpha$ ranged from 5 degrees to a maximum of 10 degrees (table 2) and when the flow angle of attack probably contributed to a small to moderate increase in scour depth at the upstream nose of the pier. When reporting relations between pier and streambed characteristics and scour depths, effective pier width was always used.

\section{Comparisons with Other Pier-Scour Data}

Pier-scour data collected for this study were compared to pier-scour data from other USGS studies that were used to develop pier-scour equations for coarse-bed streams. Historical data were retrieved from the BSDMS described by Landers and others (1996). The 508 measurements in the BSDMS database collected between 1965 and 1998 by USGS were initially screened using the following criteria:

1. Bed material was noncohesive and composed of sand and coarser particles.

2. Data for particle-size distribution of the bed material were reported in the BSDMS database.

3. Flow angle of attack on the pier $(\alpha)$ was reported as zero degrees. Sites with flow angles of attack exceeding zero degrees were not considered because it was not known what adjustments might have been made to account for $\alpha$ effects on scour depth.

4. Large, woody debris accumulation on piers was not indicated to be "substantial."

5. Measured approach velocity $\left(V_{o}\right)$ exceeded the critical velocity to initiate scour of bed material at the $\operatorname{pier}\left(V_{c 50}^{\prime}\right)$, where $V_{o} / V_{c 50}^{\prime}>1.00$.

6. All variables needed for computing scour depth were reported in the BSDMS database for the measurement or could be derived from other variables reported in BSDMS.

The initial screening resulted in 272 pier-scour measurements that met the above criteria for highway bridges in 15 States, referred to hereinafter as the BSDMS All dataset.

The measurements used for this study and measurements from the BSDMS All dataset were classified based on the size of bed material relative to pier width using the system described by Ettema (1980). In that classification, sediment size is considered: fine for $b / D_{50} \geq 130$; intermediate for $130>b / D_{50} \geq 30$; and coarse for $30>b / D_{50} \geq 8$. For $b / D_{50}<8$, sediment size is considered large and sediment typically is not eroded.

A substantial portion ( $>75$ percent) of the measurements in the BSDMS All dataset was made at sites with fine bed material based on Ettema's classification system (fig. 6, table 6). In contrast, about two-thirds of pier-scour measurements made for this study were at sites with coarse bed material, and a small percentage (about 7 percent) of those measurements were at sites on the threshold between coarse and large bed material.

All the data collected for this study and the BSDMS All dataset plot below the line reported by Raudkivi and Sutherland (1981) that showed the relation between relative pier-scour depth and relative bed-material size (fig. 6) near the clear-water and live-bed threshold $\left(V_{o} / V_{c 50}=0.9\right)$. Data plotting below the line indicate that scour is not underpredicted.

After the initial screening, the 272 measurements that make up the BSDMS All dataset were screened again for measurements where the $D_{50}$ and $D_{95}$ particle sizes were equal to or greater than $2 \mathrm{~mm}$ and $20 \mathrm{~mm}$ (respectively) so $K_{4}$ could be less than 1.0. This screening reduced the BSDMS All dataset from 272 to 90 measurements. All subsequent comparisons of BSDMS data either use the BSDMS All dataset for noncohesive bed material $(n=272)$ or the final screened dataset $(n=90)$, referred to hereinafter as the BSDMS Coarse dataset. The BSDMS Coarse dataset is comparable with data collected for this study based on FHWA criteria for $D_{50}$ and $D_{95}$ particle size that defines coarse bed material.

In addition to using Ettema's classification to compare relative bed material size (fig. 6), surface bed-material data collected for this study were compared with the BSDMS All and Coarse datasets (table 7) using the $D_{50}$ particle size and the bed-material size classification (table 3 ) to generally characterize bed material size. Using very coarse gravel 


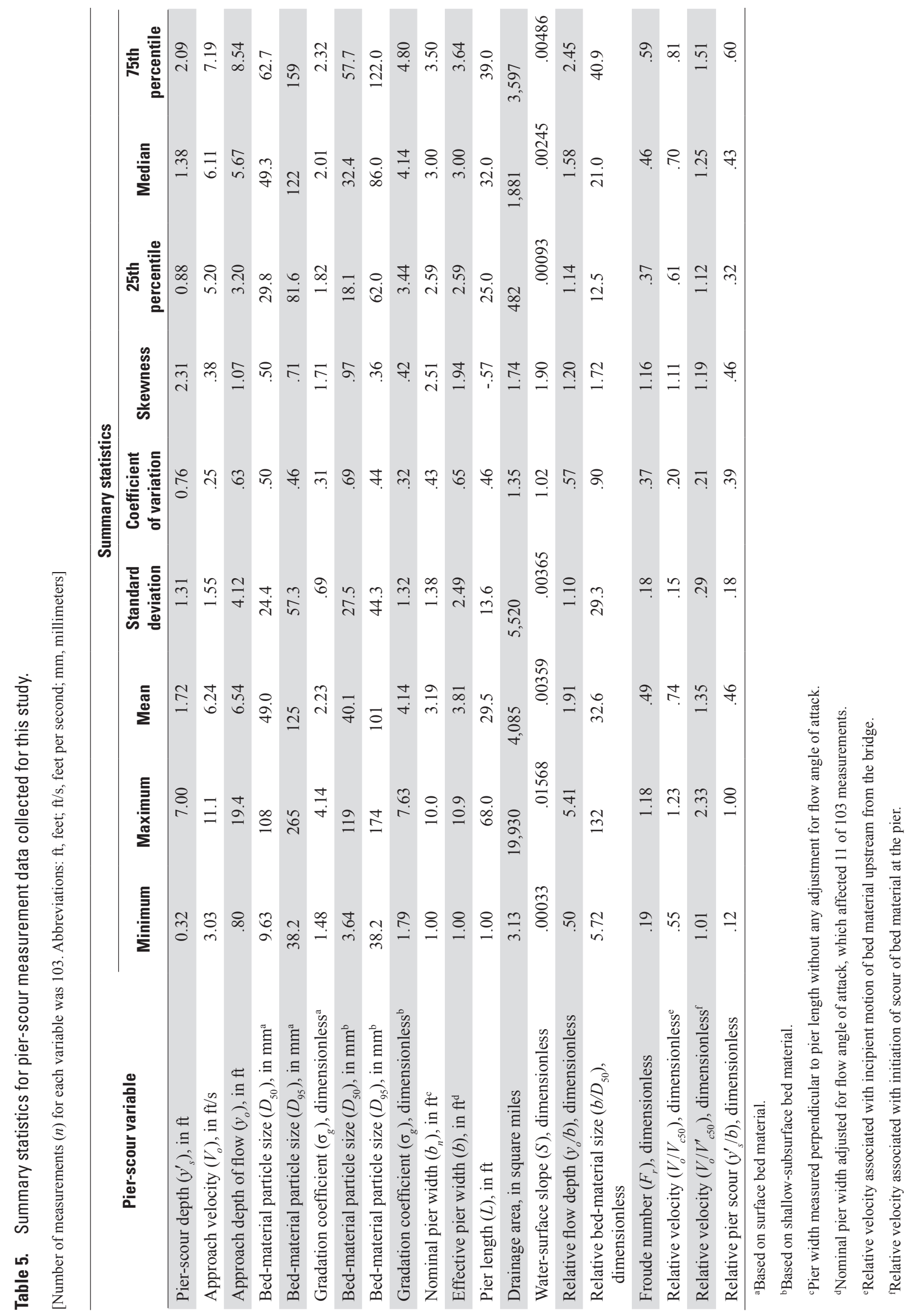




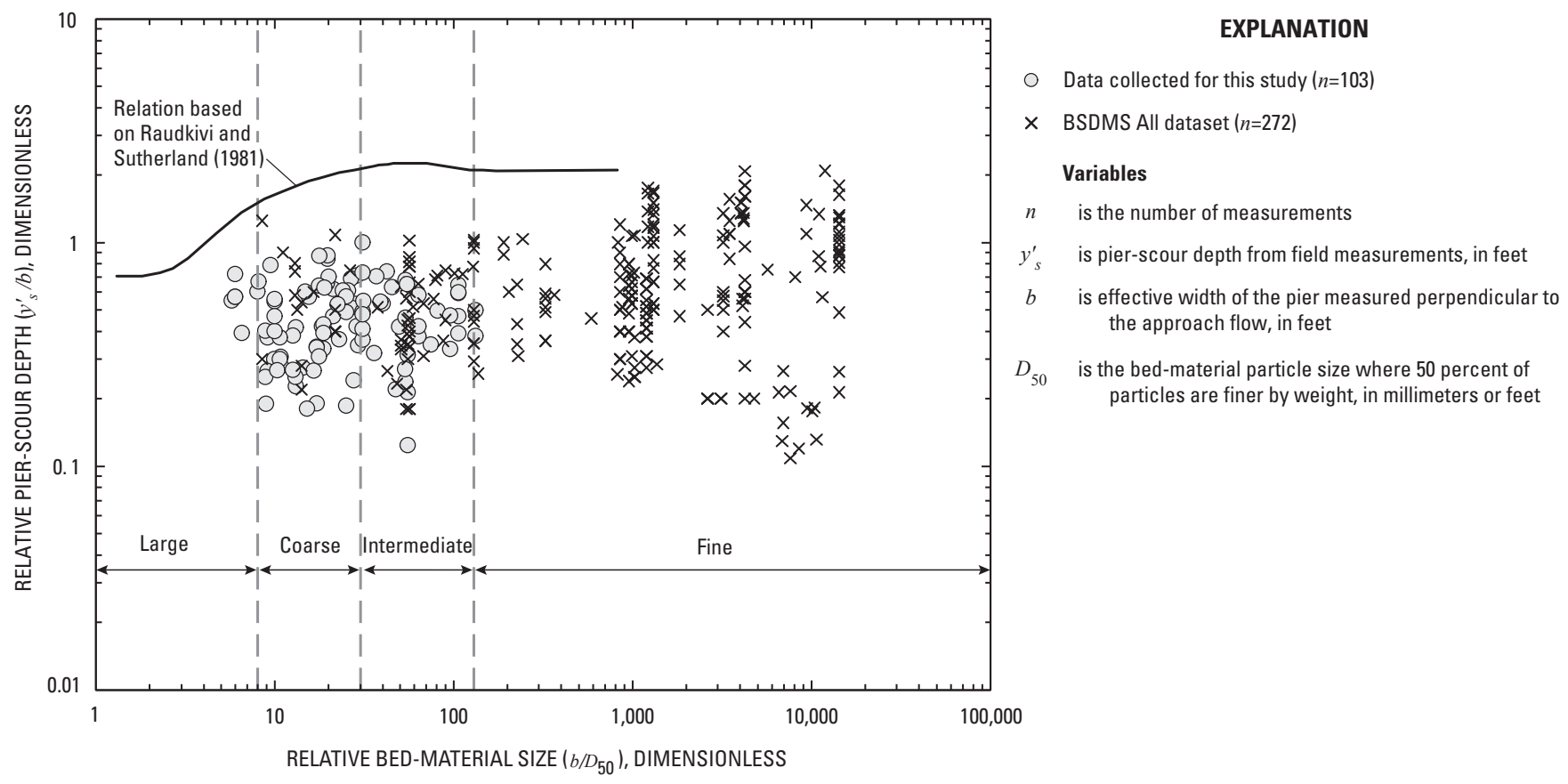

Figure 6. Comparison of pier-scour measurements collected for this study and from the Bridge Scour Data Management System (BSDMS) All dataset. Relative bed-material size criteria from Ettema (1980).

Table 6. Comparison of the relative bed-material size associated with pier-scour measurements made in this study with the Bridge Scour Data Management System (BSDMS) All dataset.

[Symbols: >, greater than; $\geq$, greater than or equal to; $<$, less than; $\left(b / D_{50}\right)$, relative bed-material size; $n=$, number of data values in dataset]

\begin{tabular}{|c|c|c|c|}
\hline \multirow{2}{*}{$\begin{array}{l}\text { Interval for relative bed-material } \\
\text { size }\left(b / D_{50}\right) \text {, dimensionless }\end{array}$} & \multirow{2}{*}{$\begin{array}{l}\text { Classification for } \\
\text { bed-material size }\end{array}$} & \multicolumn{2}{|c|}{ Percent of data in size classification } \\
\hline & & This study ( $n=103$ ) & BSDMS All dataset ( $n=272)$ \\
\hline$b / D_{50} \geq 130$ & Fine & 0.00 & 76.5 \\
\hline $130>b / D_{50} \geq 30$ & Intermediate & 33.7 & 16.9 \\
\hline $30>b / D_{50} \geq 8$ & Coarse & 59.2 & 6.6 \\
\hline$b / D_{50}<8$ & Large & 7.1 & .00 \\
\hline
\end{tabular}

${ }^{1}$ Bed-material size critera defined by Ettema (1980).

as the size reference, about 67 percent of the measurements from this study are classified very coarse gravel or larger, only about 8 percent of the BSDMS All dataset is classified very coarse gravel or larger, and about 26 percent of the BSDMS Coarse dataset is classified very coarse gravel or larger. The BSDMS datasets do not include data for shallow-subsurface bed material, however, 54 percent of the shallow-subsurface measurements from this study are classified very coarse gravel or larger. None of the data from this study or the comparable BSDMS Coarse dataset (table 7) are ripple-forming sediments $\left(D_{50}<0.6 \mathrm{~mm}\right)$, whereas a substantial portion (about 32 percent) of the BSDMS All dataset are ripple-forming sediments.
Ripple-forming sediments are more applicable to sand-bed streams, where fine noncohesive particle sizes and bed forms such as dunes are involved in the pier-scour process.

Approach velocity $\left(V_{o}\right)$ is among the most important hydraulic variables that can affect pier-scour depth. The median approach velocity for measurements collected for this study was slightly lower than the median approach velocity for measurements in the BSDMS Coarse dataset but was higher than the measurements in the BSDMS All dataset (fig. 7). The approach velocity for the measurements in the BSDMS All dataset is more variable. 
Table 7. Comparison of bed-material size classification associated with pier-scour measurements made for this study and measurements from the Bridge Scour Data Measurement System (BSDMS) Coarse and All datasets.

[Abbreviations: mm, millimeter. Symbols: $\geq$, greater than or equal to; $<$, less than; $D_{50}$, median particle size of the sample; --, not applicable; $n=$, number of data values]

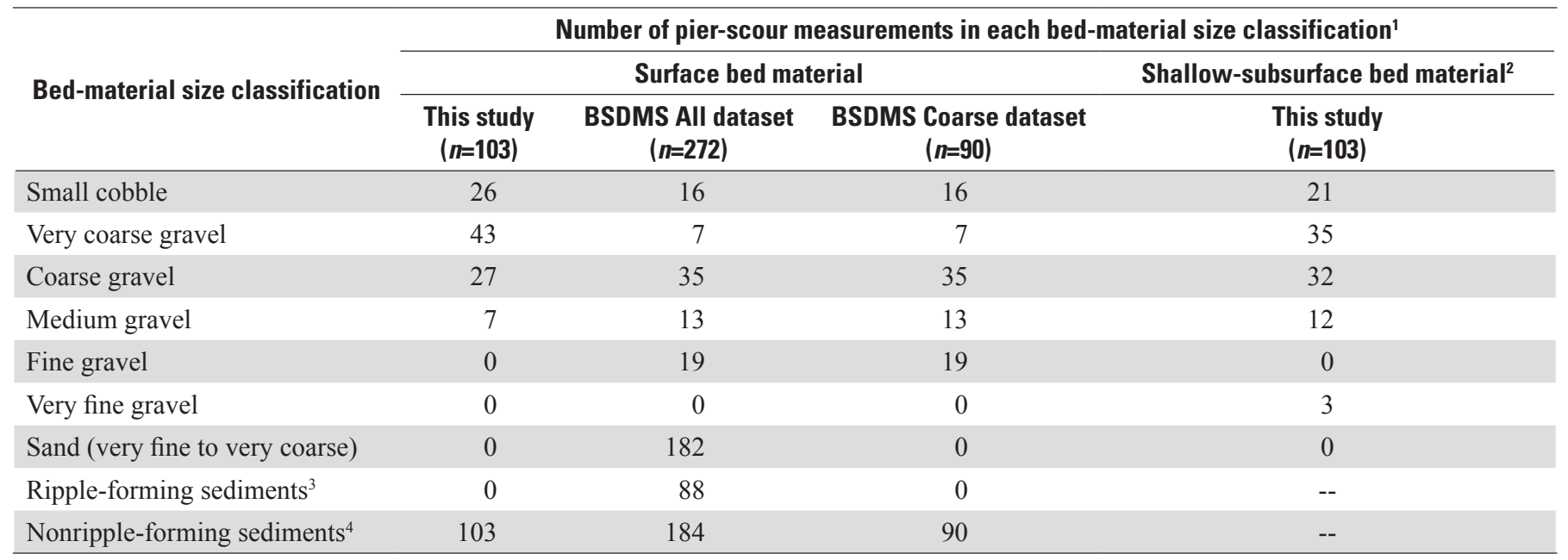

${ }^{1}$ Based on $D_{50}$ particle size of sample.

${ }^{2}$ No data reported in BSDMS for shallow-subsurface bed material.

${ }^{3} D_{50}<0.6 \mathrm{~mm}$.

${ }^{4} D_{50} \geq 0.6 \mathrm{~mm}$.
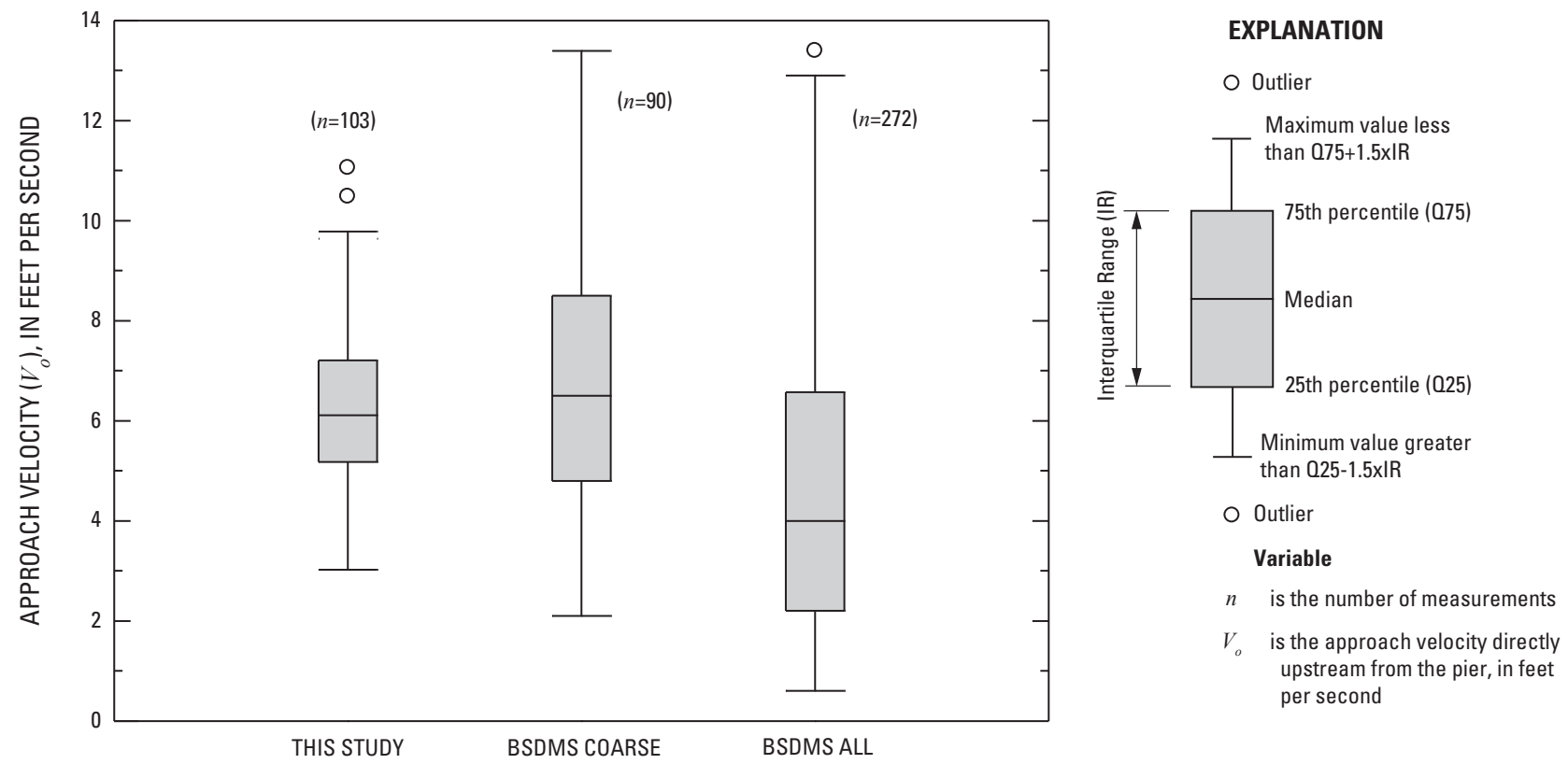

Figure 7. Comparison of approach velocities for pier-scour measurements collected for this study with the Bridge Scour Data Management System (BSDMS) Coarse and All datasets. 
Relative scour velocities $\left(V_{o} / V^{\prime}{ }_{c 0}\right)$ determined from measurements collected for this study also were compared with the BSDMS Coarse dataset (fig. 8). The threshold for initiating scour of bed material at the pier $\left(V_{o} / V_{c 50}^{\prime}>1.00\right)$ was exceeded to a greater degree by measurements in the BSDMS Coarse dataset. These higher relative scour values are likely due to the smaller bed-material size of measurements in the BSDMS Coarse dataset, compared to measurements collected for this study. Lower approach velocities can initiate scour at a pier when bed material is smaller. The median $D_{50}$ and $D_{95}$ bed-material size for data collected for this study are about 1.8 and 1.6 times (respectively) larger than the $D_{50}$ and $D_{95}$ of the BSDMS Coarse dataset (fig. 9).

In addition to comparing data used for this study to the BSDMS All and BSDMS Coarse datasets, data collected for this study also were compared to historical pier-scour measurements made in Montana by USGS during large floods. The measurements were not part of the BSDMS database. Pier-scour measurements made at sites 60, 61, and 62 (fig. 1, table 8) in 1996-97 were selected for this comparison. Nine measurements made at these three sites were for peak streamflows approximating the 100-, 10-, and 5-year recurrence intervals, which are much greater than any recurrence intervals associated with measurements made for this study and provide an independent check on the envelope curves bounding the upper end of both the data collected for this study and BSDMS data combined.
While conducting research leading to the development of $K_{4}$, Mueller (1996) introduced the concept of an idealized $K_{4}$ :

$$
\text { Idealized } K_{4}=\frac{y_{s}^{\prime}}{y_{s}},
$$

where

$$
\begin{gathered}
\begin{array}{c}
y_{s}^{\prime} \\
\text { is pier-scour depth from field measurements, } \\
\text { in feet; }
\end{array} \\
\begin{array}{c}
\text { is pier scour computed by using the basic } \\
\text { form of the HEC-18 equation without } K_{4} \\
\text { applied (equation 4), in feet; and }
\end{array} \\
K_{4} \quad \begin{array}{l}
\text { is dimensionless. }
\end{array}
\end{gathered}
$$

The idealized $K_{4}$ is the relative error between measured scour and computed scour. Idealized $K_{4}$ values were computed for pier-scour measurements collected for this study along with Mueller's velocity-intensity ratios (equation 10 ). The resulting idealized $K_{4}$ and Mueller's velocity-intensity ratios were then plotted in relation to each other for the pier-scour measurements collected for this study, the BSDMS Coarse dataset, and historical pier-scour measurements from sites 60-62 (fig. 10). The dashed line (fig. 10) defines an idealized $K_{4}$ according to HEC-18 criteria currently (2011) used (Richardson and Davis, 2001), and represents the envelope curve under which all idealized $K_{4}$ values derived from field data should plot.

Data collected for this study included lower Mueller velocity-intensity ratios than the BSDMS Coarse dataset and
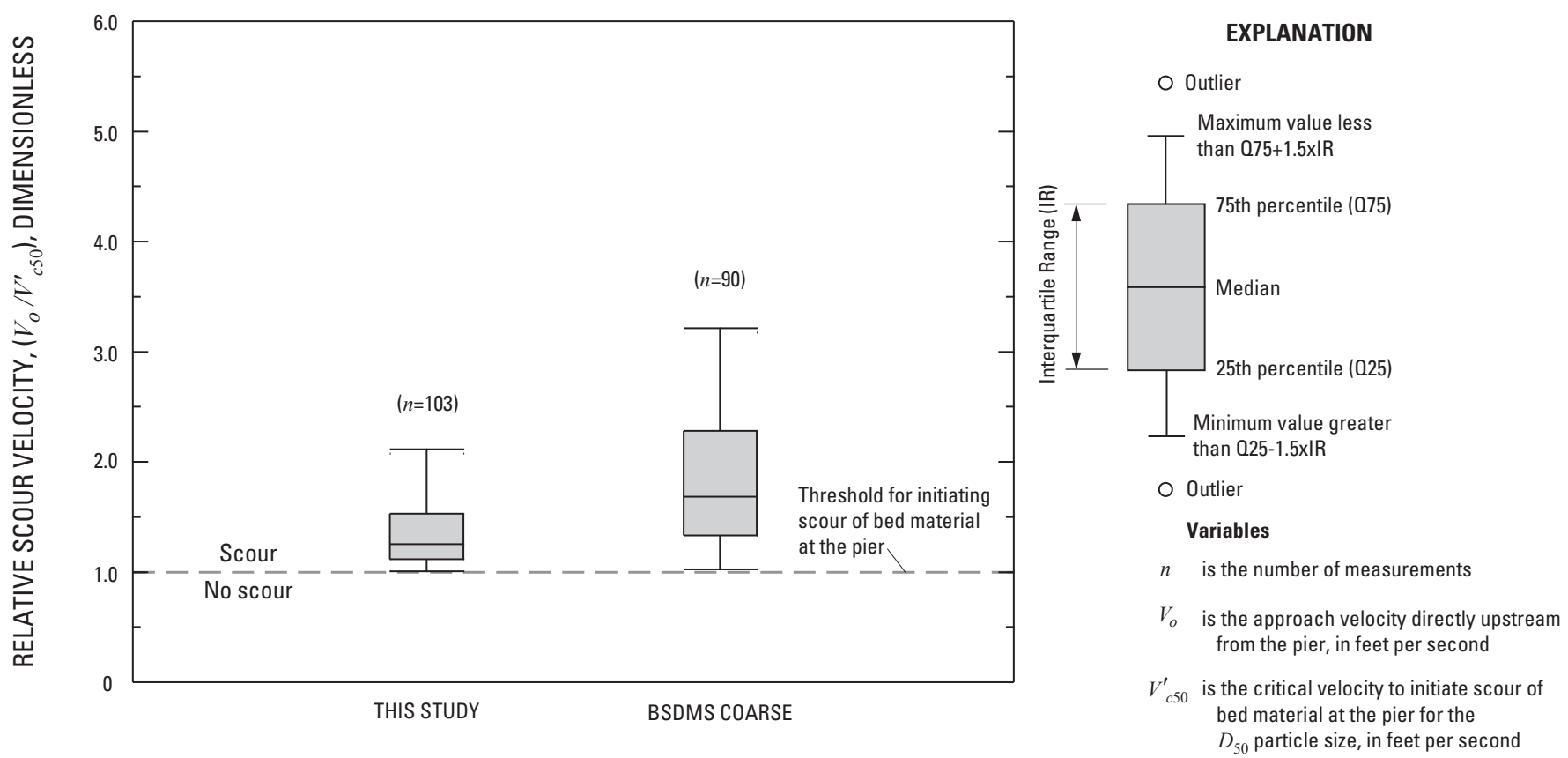

Figure 8. Comparison of relative scour velocities for pier-scour measurements collected for this study and from the Bridge Scour Data Management System (BSDMS) Coarse dataset. 


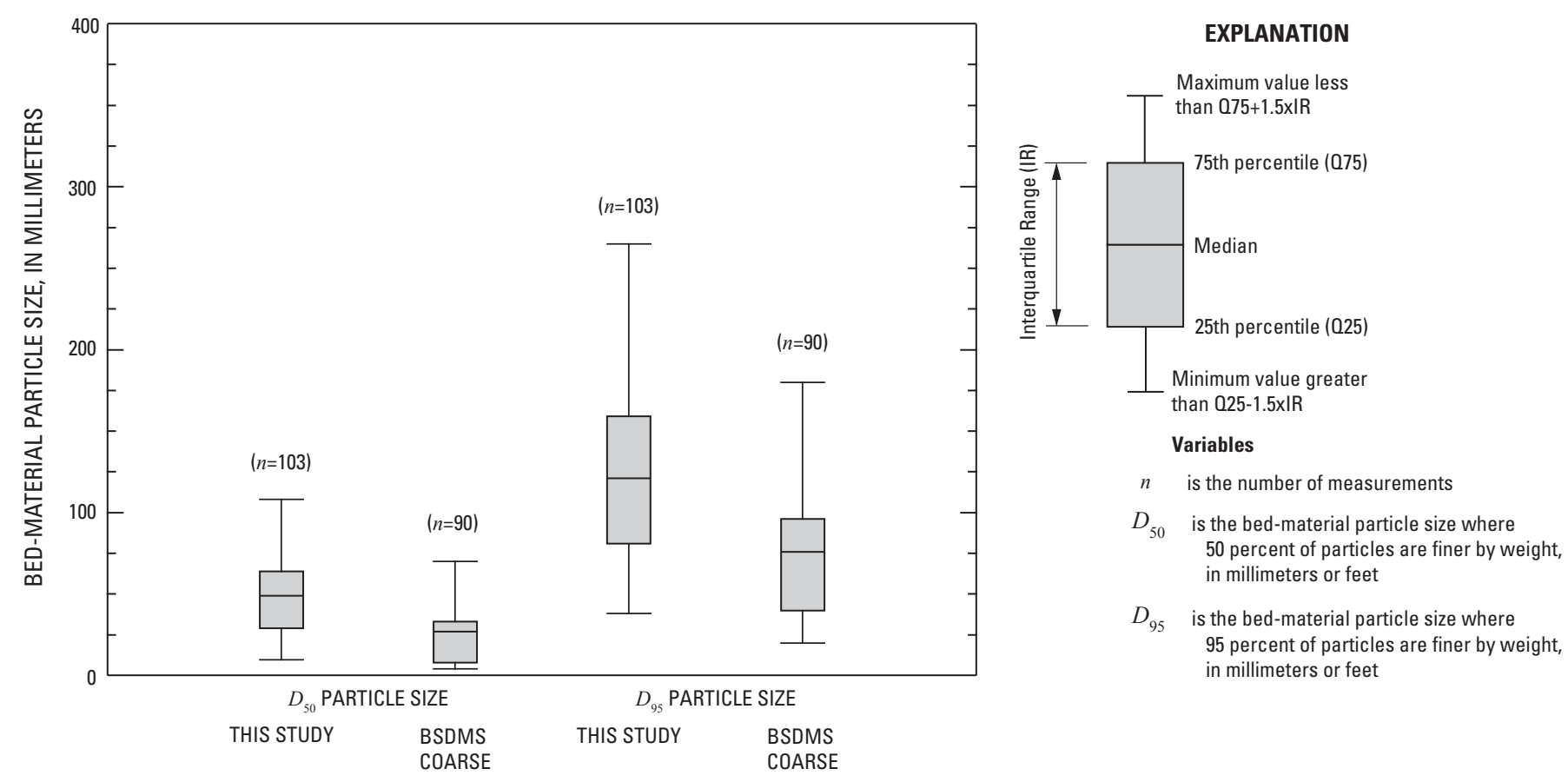

Figure 9. Comparison of bed-material particle size $\left(D_{50}\right.$ and $\left.D_{95}\right)$ for pier-scour measurements collected for this study with the Bridge Scour Data Management System (BSDMS) Coarse dataset.

historical data from sites 60-62, which supports Mueller's (1996) envelope curve for $K_{4}$ for lower velocity-intensity ratios (fig. 10). Nearly all data collected for this study plot below the idealized $K_{4}$-envelope curve; one data point plots on the curve and six data points for five different sites (sites 20,37, 51, 55, and 57) plot slightly above the curve. Idealized $K_{4}$ values plotting above the envelope curve indicate that current methods (2011) underpredict pier scour and that factors not described by current (2011) equations led to scour underprediction. This underpredicted scour depth had a median residual, or difference between measured and computed scour depth, of about $0.2 \mathrm{ft}$. The most likely factor causing scour underprediction for the five sites where pier scour was measured for this study was the presence of woody debris on piers, noted as a moderate effect at four of the five sites (table 2). While this and other factors were not considered substantial enough to remove measurements from the dataset, the factors very likely contributed to the pier-scour depth measured in the field but not predicted by the HEC-18 equations (fig. 10). Additionally, five sites from the BSDMS Coarse dataset show underpredicted scour with a median residual of $0.41 \mathrm{ft}$ (fig. 10). The five BSDMS sites were discussed by Mueller and Wagner (1995), where four of the five idealized $K_{4}$ values were found to plot below the envelope line when the $D_{50}$ and $D_{95}$ variables used in the prediction equations were derived from composite samples of bed-material obtained at each site.

Mueller and Wagner (2005) proposed a different equation for computing $K_{4}$ (equation 20), which related $K_{4}$ and relative bed-material size. When plotted, the equation defines an envelope curve that represents the maximum idealized $K_{4}$ for a given bed-material size. Idealized $K_{4}$ and relative bed-material sizes for the pier-scour measurements collected for this study, measurements from the BSDMS Coarse dataset, and historical pier-scour measurements from sites 60-62 were plotted along with the equation Mueller and Wagner (2005) proposed (fig. 11). All data plot below the $K_{4}$-envelope curve proposed by Mueller and Wagner (2005), indicating that scour was not underpredicted. The lower end of the relative bed-material size scale is mostly populated with idealized $K_{4}$ values computed from data collected for this study because of the larger bedmaterial sizes involved (fig. 11). The relation between idealized $K_{4}$ and relative bed-material size are similar for data collected for this study, the BSDMS Coarse dataset, and historical data for sites 60-62 and therefore, all data support the Mueller and Wagner (2005) envelope curve because pier scour was always overpredicted.

The maximum value of relative pier scour $\left(y_{s}^{\prime} / b\right)$ obtained in the study was 1.00 (table 5), and the maximum values observed in the two BSDMS datasets (All, Coarse) were 2.09 and 1.25 , respectively. Research indicates that maximum scour generally does not exceed about 2.4 times the effective pier width $\left(y_{s}^{\prime}=2.4 b\right)$ for measurements with Froude numbers less than about 0.8 (Richardson and Davis, 2001), which is supported by the data collected for this study and BSDMS datasets. The largest maximum of 2.09 (BSDMS All dataset) includes data for sites with sand bed material, whereas the lower maxima (1.00 and 1.25) include data collected for this study and from the BSDMS Coarse dataset for 


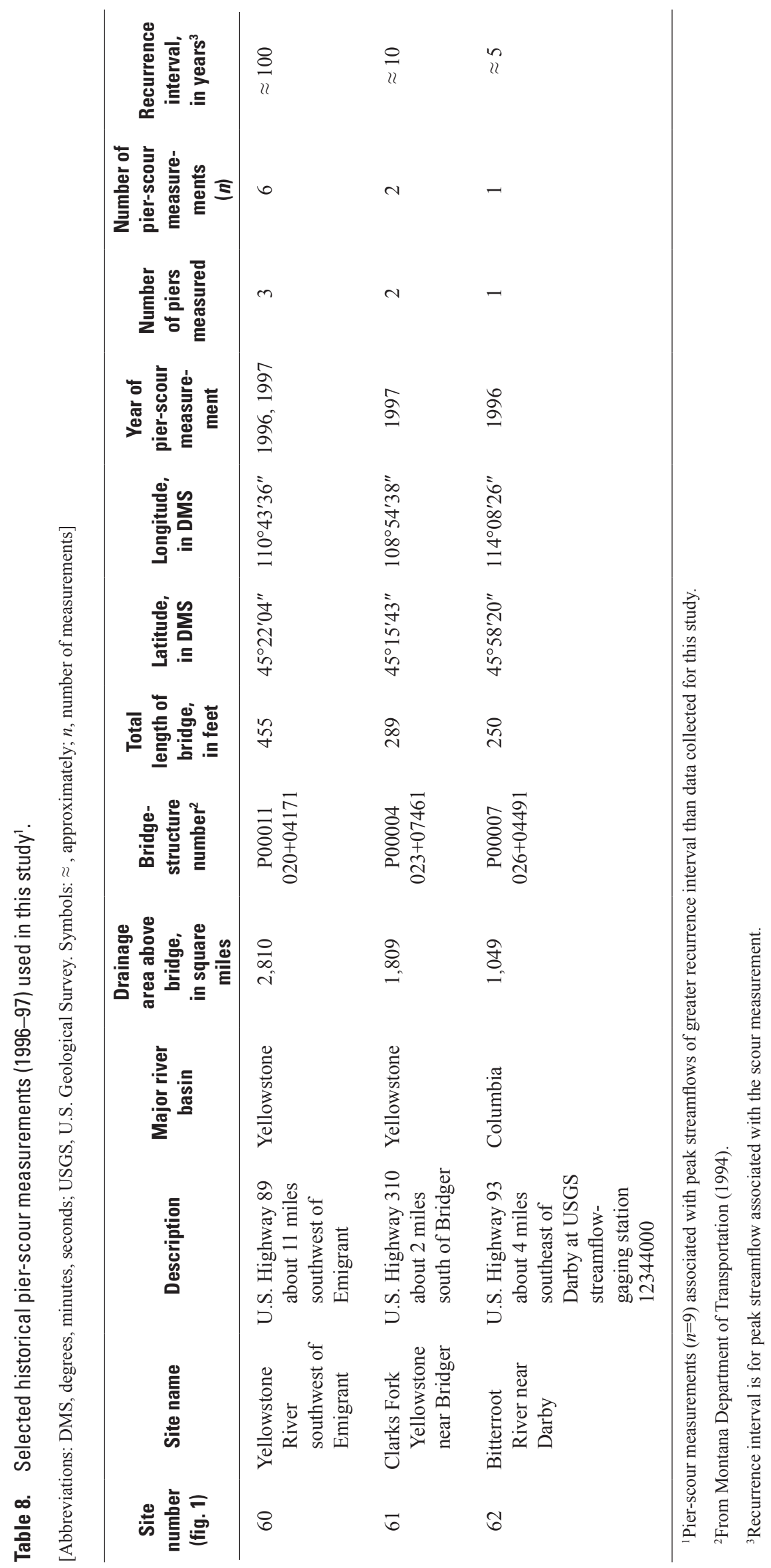




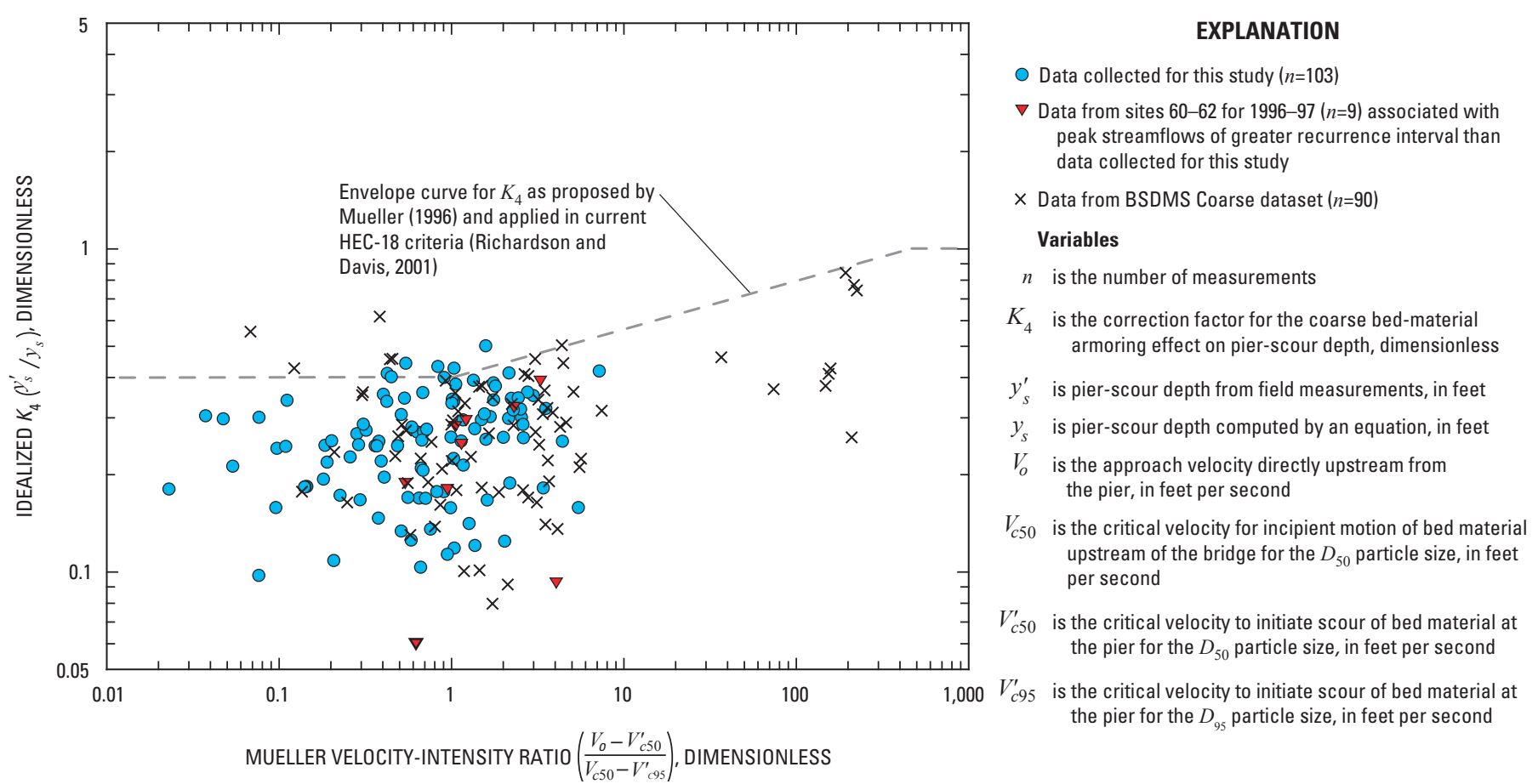

Figure 10. Comparison of idealized $K_{4}$ to Mueller velocity-intensity ratios for pier-scour measurements collected for this study, historical pier-scour measurements from Montana, and pier-scour measurements in the Bridge Scour Data Management System (BSDMS).

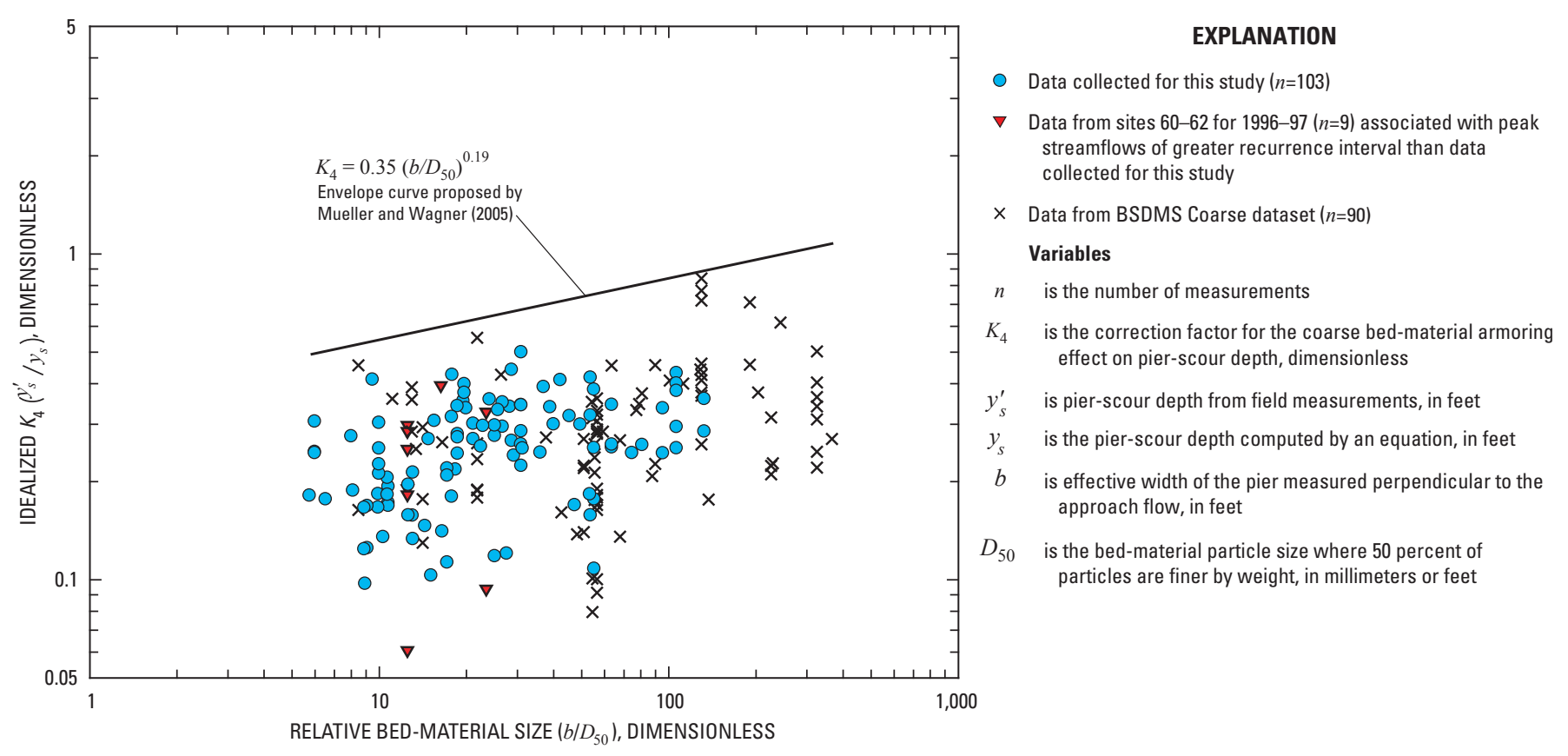

Figure 11. Comparison of idealized $K_{4}$ to relative bed-material size for pier-scour measurements collected for this study, historical pierscour measurements from Montana, and pier-scour measurements in the Bridge Scour Data Management System (BSDMS) Coarse dataset. 
sites characterized by much coarser bed material. These results reaffirm the general finding that pier scour is inversely related to bed-material size.

\section{Comparisons of Measured and Computed Scour}

The most reliable pier-scour equation minimizes underpredicted scour depth (positive residual) as the principal criterion but also does not unreasonably overpredict scour depth (negative residual). Scour depth was computed for the measurements collected in this study using the basic HEC-18 equation and five pier-scour equations described previously that use the $K_{4}$ correction factor for the armoring effect of coarse-bed material:

1. The basic HEC-18 equation with no $K_{4}$ factor (equation 3 or 4). This is the original equation from which other equations have evolved and is the equation (equation 4) used in comparisons involving the idealized $K_{4}$ (equation 22).

2. The HEC-18 equation (equation 5), with $K_{4}$ determined by equation 11 as proposed by Mueller (1996, where $0.4 \leq K_{4} \leq 1.0$ ) and used by Richardson and Davis (2001). This equation is currently (2011) recommended by the FHWA and is referred to hereinafter as the HEC-18- $K_{4} \mathrm{Mu}$ equation.

3. The HEC-18- $K_{4} \mathrm{Mu}$ equation (equation 5 ) with the current (2011) FHWA constraint $\left(0.4 \leq K_{4} \leq 1.0\right)$ removed and $0.0 \leq K_{4} \leq 1.0$ is applied instead. Values of $K_{4}$ determined by equation 11 to be less than 0.4 are, therefore, used in equation 5. This version of equation 5 is referred to hereinafter as the HEC-18$K_{4} \mathrm{Mu}^{\prime}$ equation.

4. The equation developed using nonuniform sediment mixtures (equation 13) by Molinas (2003), referred to hereinafter as the Molinas (2003) equation.

5. A variation of the HEC-18 equation (equation 19) proposed by Molinas (2003), with $K_{4}$ determined by equation 17 and referred to hereinafter as the HEC$18-K_{4}$ Mo equation.

6. The HEC-18 equation (equation 5), with $K_{4}$ determined by equation 20 as proposed by Mueller and Wagner (2005) and referred to hereinafter as the HEC-18- $K_{4} \mathrm{MW}$ equation.

Computed scour depths were compared to measured scour depths using scatter plots (fig. 12) and boxplots of residuals (fig. 13) to evaluate the reliability of the equations to predict scour. Additionally, positive and negative residuals of scour were computed and reported here because of the implication each type of residual separately has to bridge foundation design. The evaluation showed:
- The basic HEC-18 equation (fig. $12 A$ and fig. 13 ) did not underpredict scour depth at any site, but scour depth was substantially overpredicted (median and maximum overpredicted residuals of about $-4.0 \mathrm{ft}$ and $-12.4 \mathrm{ft}$, respectively).

- The HEC-18- $K_{4} \mathrm{Mu}$ equation (fig. $12 B$ and fig. 13 ) underpredicted scour depth six times at five different sites (median and maximum underpredicted residuals of about $0.2 \mathrm{ft}$ and $0.5 \mathrm{ft}$, respectively) and moderately overpredicted scour depth (median and maximum overpredicted residuals of about $-0.9 \mathrm{ft}$ and $-4.4 \mathrm{ft}$, respectively).

- The HEC-18- $K_{4} \mathrm{Mu}$ ' equation (fig. $12 C$ and fig. 13 ) underpredicted scour depth 12 times at 9 different sites (median and maximum underpredicted residuals of about $0.3 \mathrm{ft}$ and $0.8 \mathrm{ft}$, respectively) and moderately overpredicted scour depth (median and maximum overpredicted residuals of about $-0.7 \mathrm{ft}$ and $-4.4 \mathrm{ft}$, respectively) similar to the HEC- $18-K_{4} \mathrm{Mu}$ equation.

- The Molinas (2003) equation (fig. $12 D$ and fig. 13) underpredicted scour depth 35 times at 23 different sites (median and maximum underpredicted residuals of about $0.4 \mathrm{ft}$ and $2.0 \mathrm{ft}$, respectively) and moderately overpredicted scour depth (median and maximum overpredicted residuals of about $-0.6 \mathrm{ft}$ and $-2.8 \mathrm{ft}$, respectively) similar to the HEC- $18-K_{4} \mathrm{Mu}$ and HEC$18-K_{4} \mathrm{Mu}^{\prime}$ equations.

- The HEC-18- $K_{4}$ Mo equation (fig. $12 E$ and fig. 13) slightly underpredicted scour depth at three sites (median and maximum underpredicted residuals of about $0.1 \mathrm{ft}$ and $0.2 \mathrm{ft}$, respectively), but overpredicted scour depth more substantially (median and maximum overpredicted residuals of about $-2.0 \mathrm{ft}$ and $-8.6 \mathrm{ft}$, respectively) compared to the HEC- $18-K_{4} \mathrm{Mu}$, HEC-18- $K_{4} \mathrm{Mu}^{\prime}$, and Molinas (2003) equations.

- The HEC-18- $K_{4} \mathrm{MW}$ equation (fig. $12 F$ and fig. 13 ) did not underpredict scour depth at any site, but scour depth was overpredicted (median and maximum overpredicted residuals of about $-1.9 \mathrm{ft}$ and $-9.9 \mathrm{ft}$, respectively) similar to the HEC-18- $K_{4}$ Mo equation.

Finally, boxplots summarizing residuals for the six equations (fig. 13) are consistent with the conclusion of Chase and Holnbeck (2004), which indicated that the HEC-18- $K_{4} \mathrm{Mu}$ equation generally predicted scour depth in closer agreement to measured scour than the other equations used for computing pier-scour depth in coarse-bed streams. Furthermore, the magnitude of the residuals of underpredicted and overpredicted scour depth was the lowest using the HEC-18- $K_{4}$ Mu equation. 

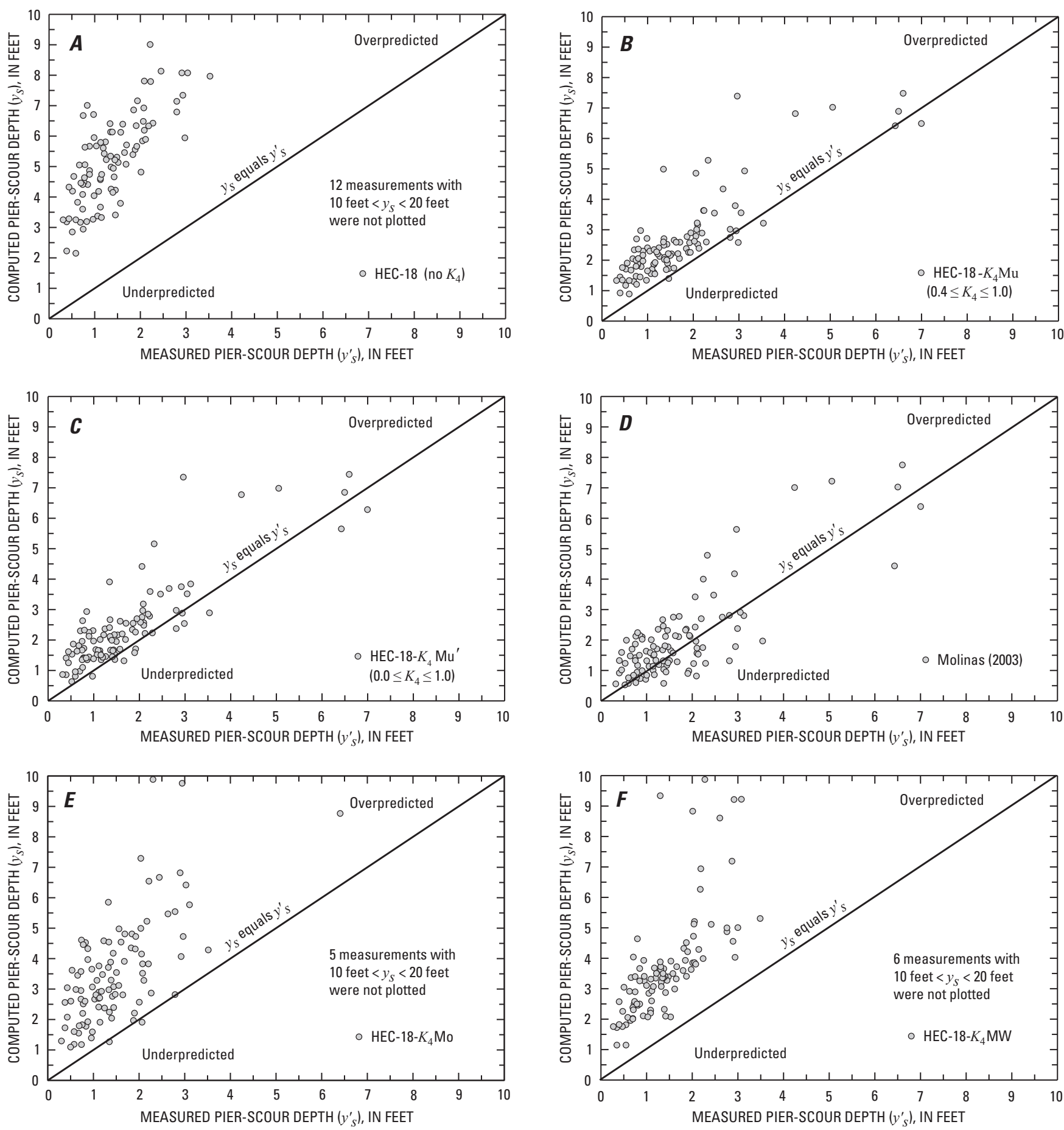

\section{EXPLANATION}

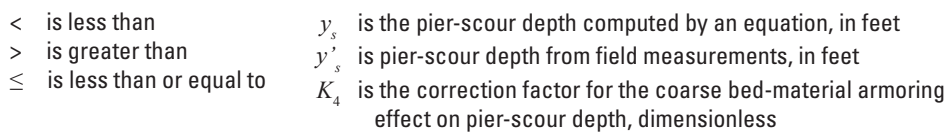

Figure 12. Comparison of measured with computed pier-scour depths for data collected for this study using selected pier-scour equations. $A$, Using the basic HEC-18 equation without $K_{4}$. $B$, Using the HEC-18- $K_{4}$ Mu equation, where $0.4 \leq K_{4} \leq 1.0$. $C, U$ sing the HEC-18- $K_{4} \mathrm{Mu}^{\prime}$ equation, where $0.0 \leq K_{4} \leq 1.0$. $D$, Using the Molinas (2003) equation. $E$, Using the HEC-18- $K_{4}$ Mo equation. $F$, Using the HEC-18- $K_{4} \mathrm{MW}$ equation. 

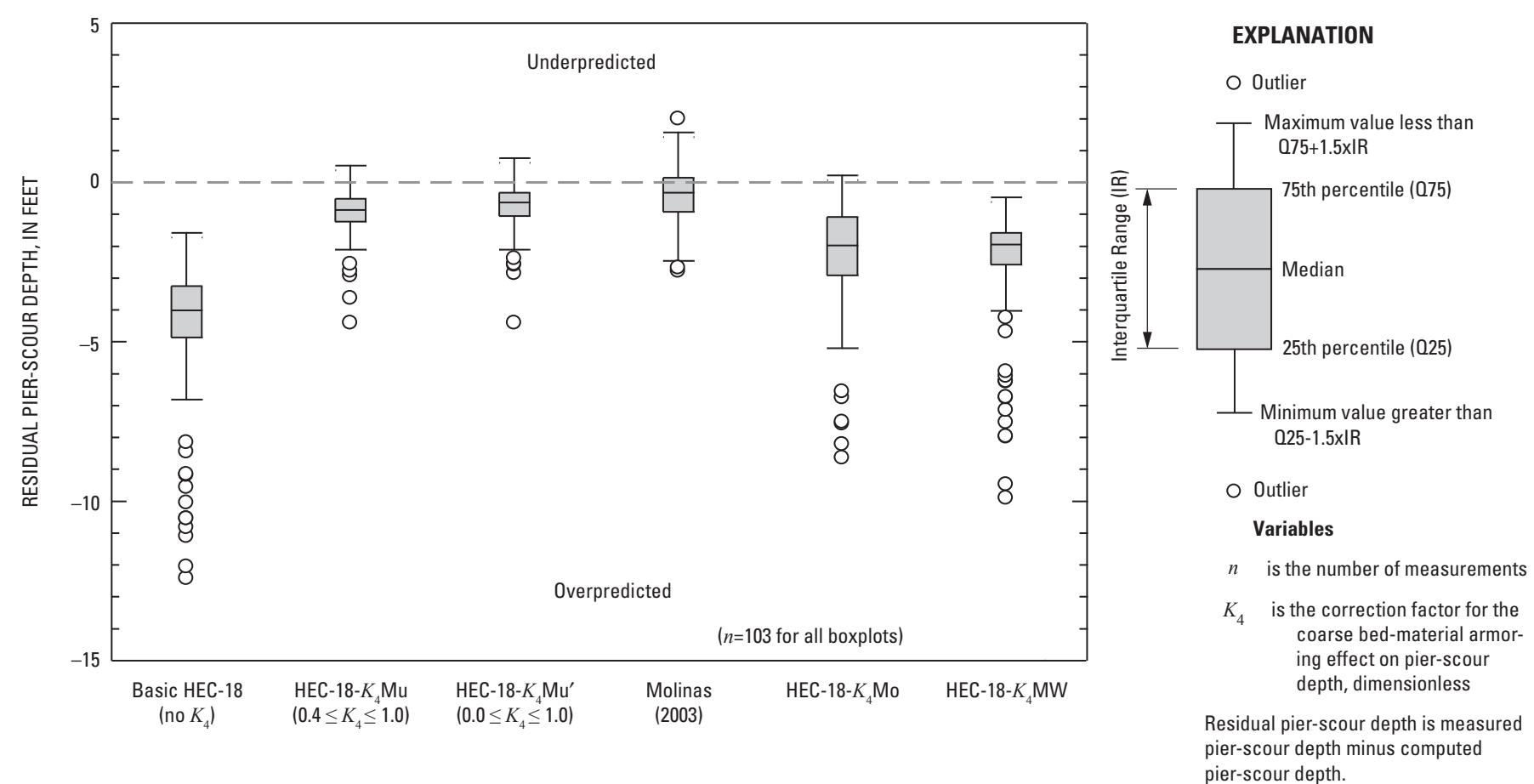

Figure 13. Comparison of residual pier-scour depth for six pier-scour equations evaluated for this study.

\section{Effects of Bed-Material Characteristics on Pier Scour}

Bed-material data were collected for the surface or armor layer as part of each measurement. In addition, similar data also were collected for bed material in the shallow-subsurface bed material immediately below the surface layer. The shallow-subsurface layer included only that part of the streambed where scour and depositional processes are active (active layer). These detailed bed-material data for each layer (table 9) were used to assess the effects of bed-material characteristics on pier scour in coarse-bed streams in Montana.

Assessment of the effects of bed-material characteristics on pier scour began with a detailed examination of the relation of bed-material size and gradation of the surface layer to relative pier scour. This effort largely involved applying the work of previous researchers to the pier-scour measurements made on coarse-bed streams for this study. Next, the effects of shallow-subsurface bed-material characteristics on pier scour were assessed and compared to the effects of the surface bedmaterial characteristics. In particular, the differences in pierscour prediction caused by using bed-material characteristics of one layer or the other were examined. Finally, the effects of differences in bed-material size and gradation between the layers on pier scour were each assessed separately and then the combined effects of differences in bed-material size and gradation between the two layers were assessed.

\section{Effects of Surface Bed-Material Characteristics}

Early bridge scour studies did not consider surface bed-material characteristics, but in the mid-1960s researchers began to note that surface bed-material size had an effect on pier-scour depth (Shen and others, 1966). Later studies showed that the gradation of the surface bed material also affected pier-scour depth (Ettema 1976, 1980; Chiew, 1984; Baker, 1986; and Abdou, 1993). The effect of bed-material size and gradation on scour depth was investigated using data collected for this study, the BSDMS All dataset, and the BSDMS Coarse dataset to confirm and extend the findings of previous studies. Data from these three datasets were compared to previously published relations of relative pier scour $\left(y_{s}^{\prime} / b\right)$ and relative velocity $\left(V_{o} / V_{c 50}\right)$. Relative velocity was computed based on the critical velocity for incipient motion of bed material upstream from the bridge $\left(V_{c 50}\right)$. Comparisons also were made using relative velocity computed based on the critical velocity to initiate scour of bed material at the pier $\left(V_{c 50}^{\prime}\right)$. This was considered appropriate because most pierscour data collected for this study reflect clear-water scour conditions, where incipient motion of the bed material and substantial sediment supply to the scour hole was not a factor.

Recognizing the relation between bed-material characteristics and pier-scour depth, researchers have continued to improve scour-prediction equations by incorporating mathematical expressions that attempt to account for bed-material 
Table 9. Particle-size distribution and gradation coefficient for surface and shallow-subsurface bed-material data collected for this study.

[All pier-scour measurement data were obtained for bed material that was noncohesive. Symbols: $D_{i}$, bed-material particle size where $i$ percent of particles are finer by weight, in millimeters; $\sigma_{g, s}$, gradation coefficient of the surface bed material, dimensionless; $\sigma_{g, s s}$, gradation coefficient of the shallow-subsurface bed material, dimensionless]

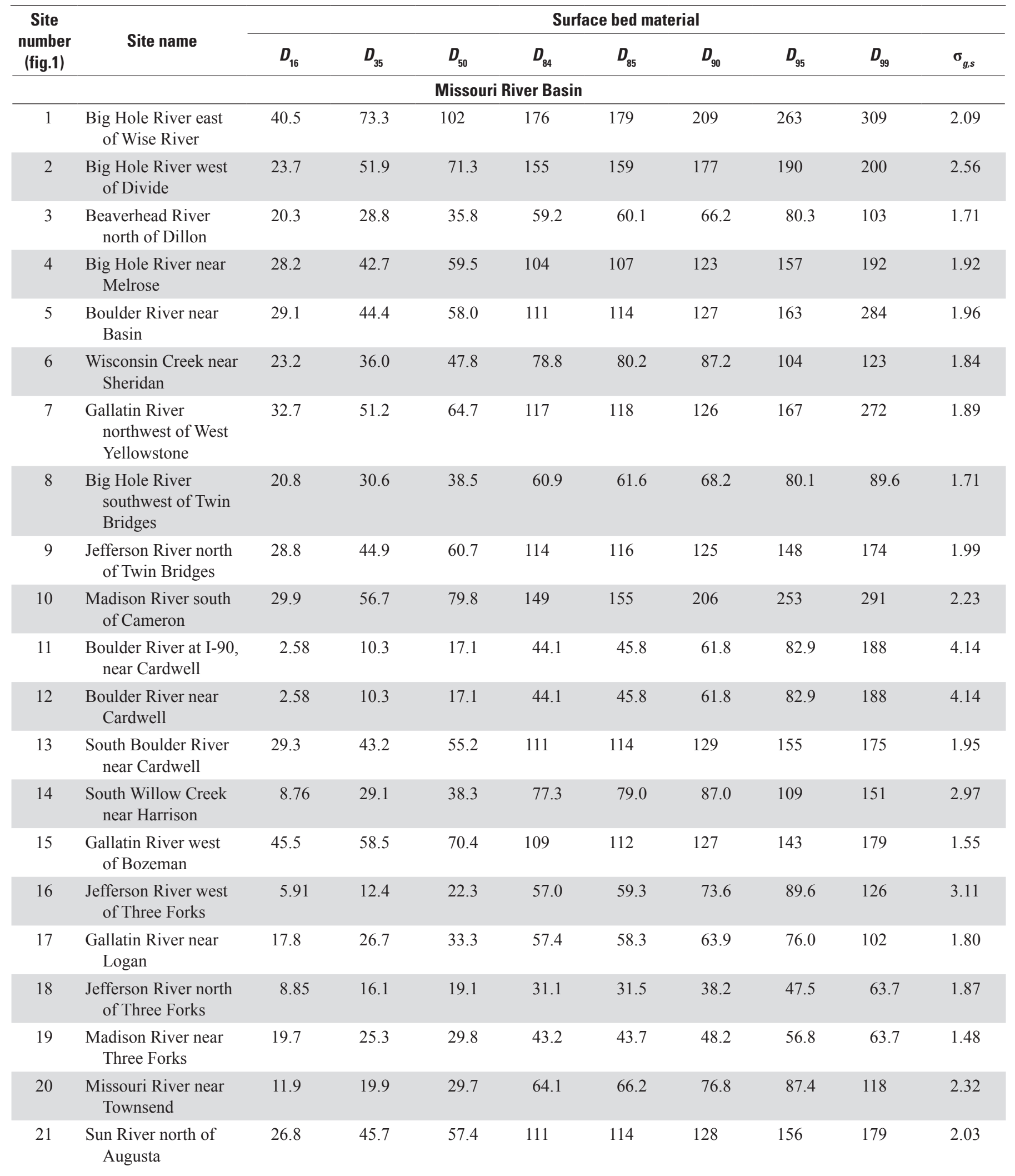




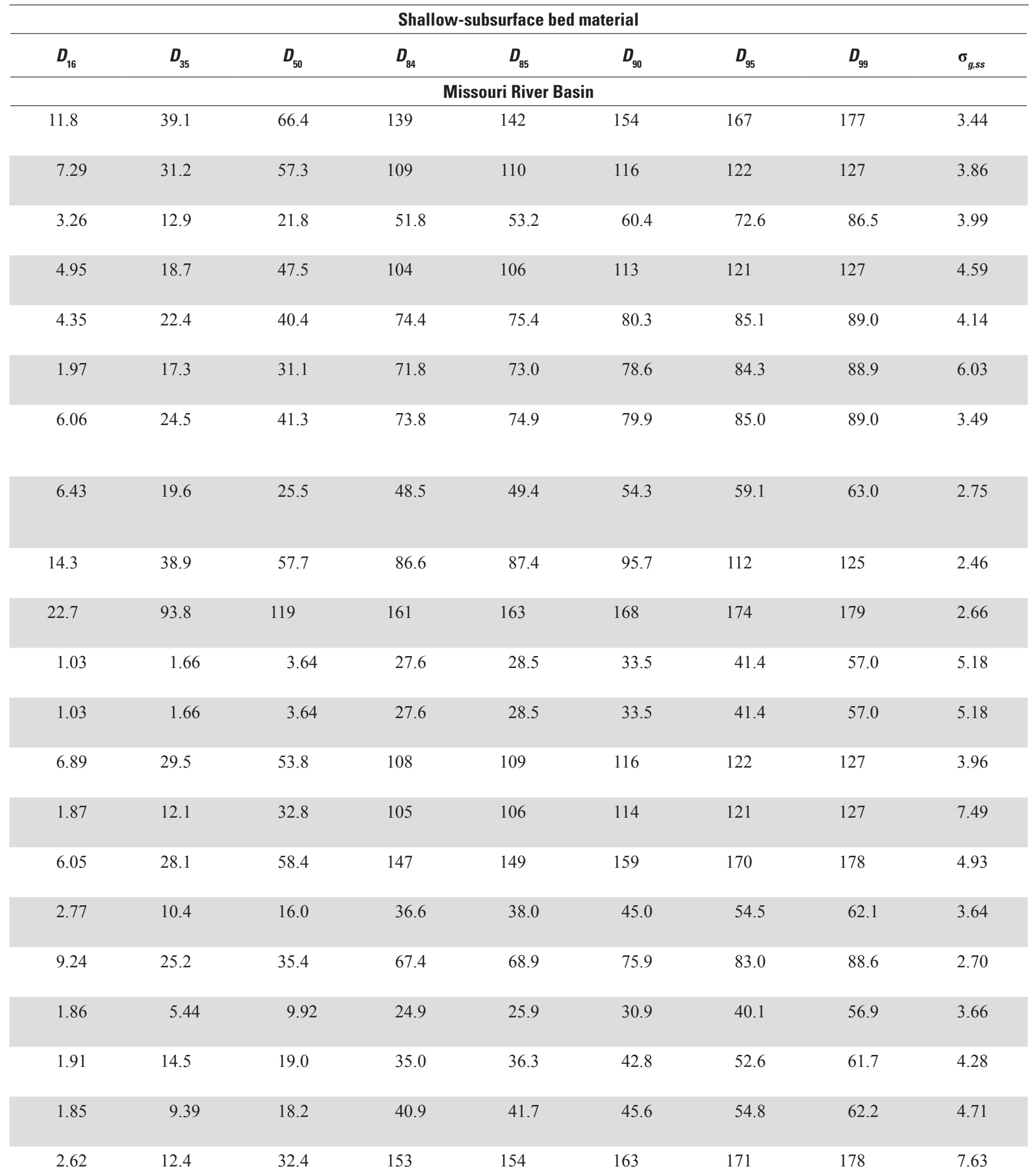


Table 9. Particle-size distribution and gradation coefficient for surface and shallow-subsurface bed-material data collected for this study.-Continued

[All pier-scour measurement data were obtained for bed material that was noncohesive. Symbols: $D_{i}$, bed-material particle size where $i$ percent of particles are finer by weight, in millimeters; $\sigma_{g, s}$, gradation coefficient of the surface bed material, dimensionless; $\sigma_{g, s s}$, gradation coefficient of the shallow-subsurface bed material, dimensionless]

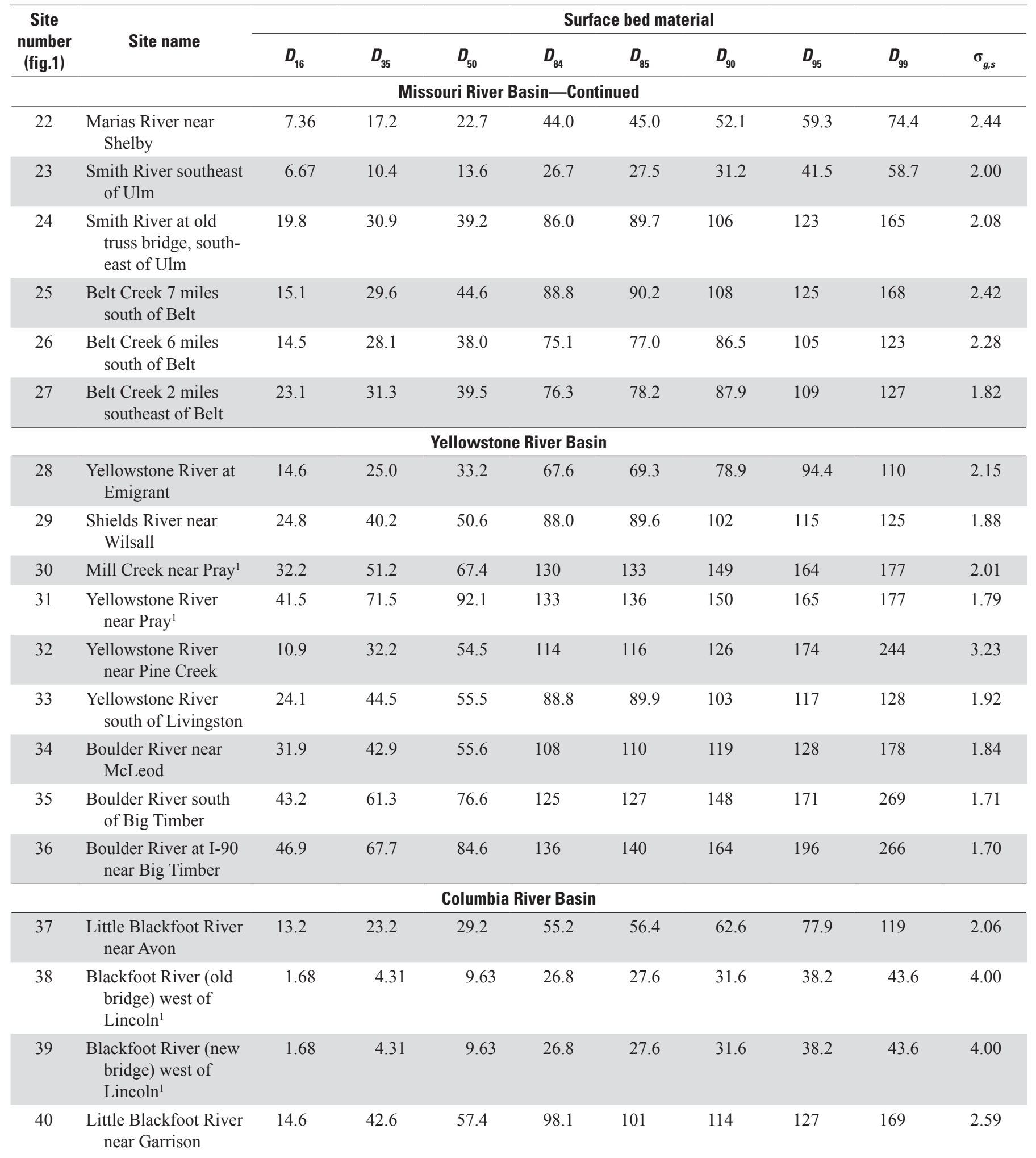




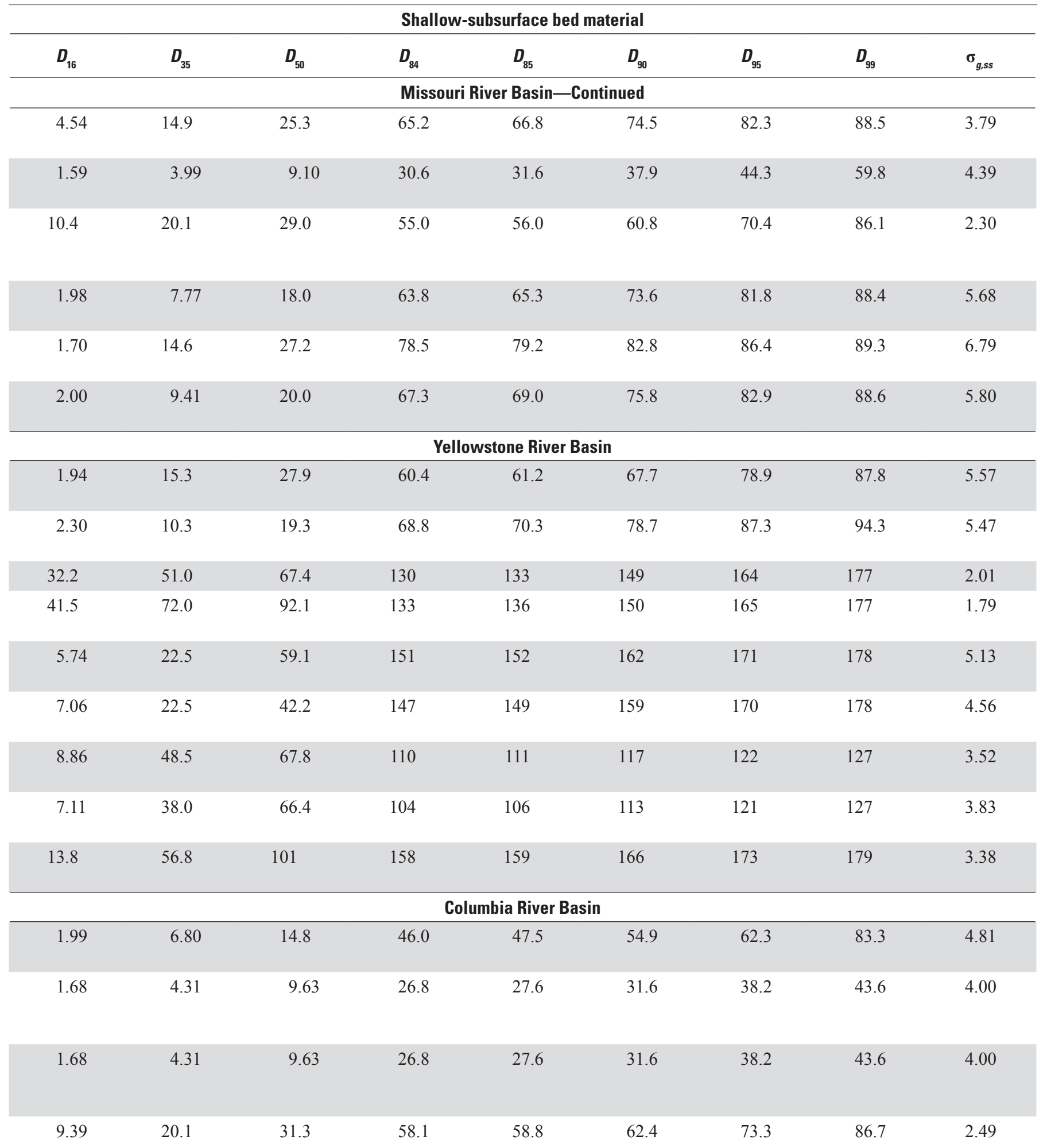


Table 9. Particle-size distribution and gradation coefficient for surface and shallow-subsurface bed-material data collected for this study.-Continued

[All pier-scour measurement data were obtained for bed material that was noncohesive. Symbols: $D_{i}$, bed-material particle size where $i$ percent of particles are finer by weight, in millimeters; $\sigma_{g, s}$, gradation coefficient of the surface bed material, dimensionless; $\sigma_{g, s s}$, gradation coefficient of the shallow-subsurface bed material, dimensionless]

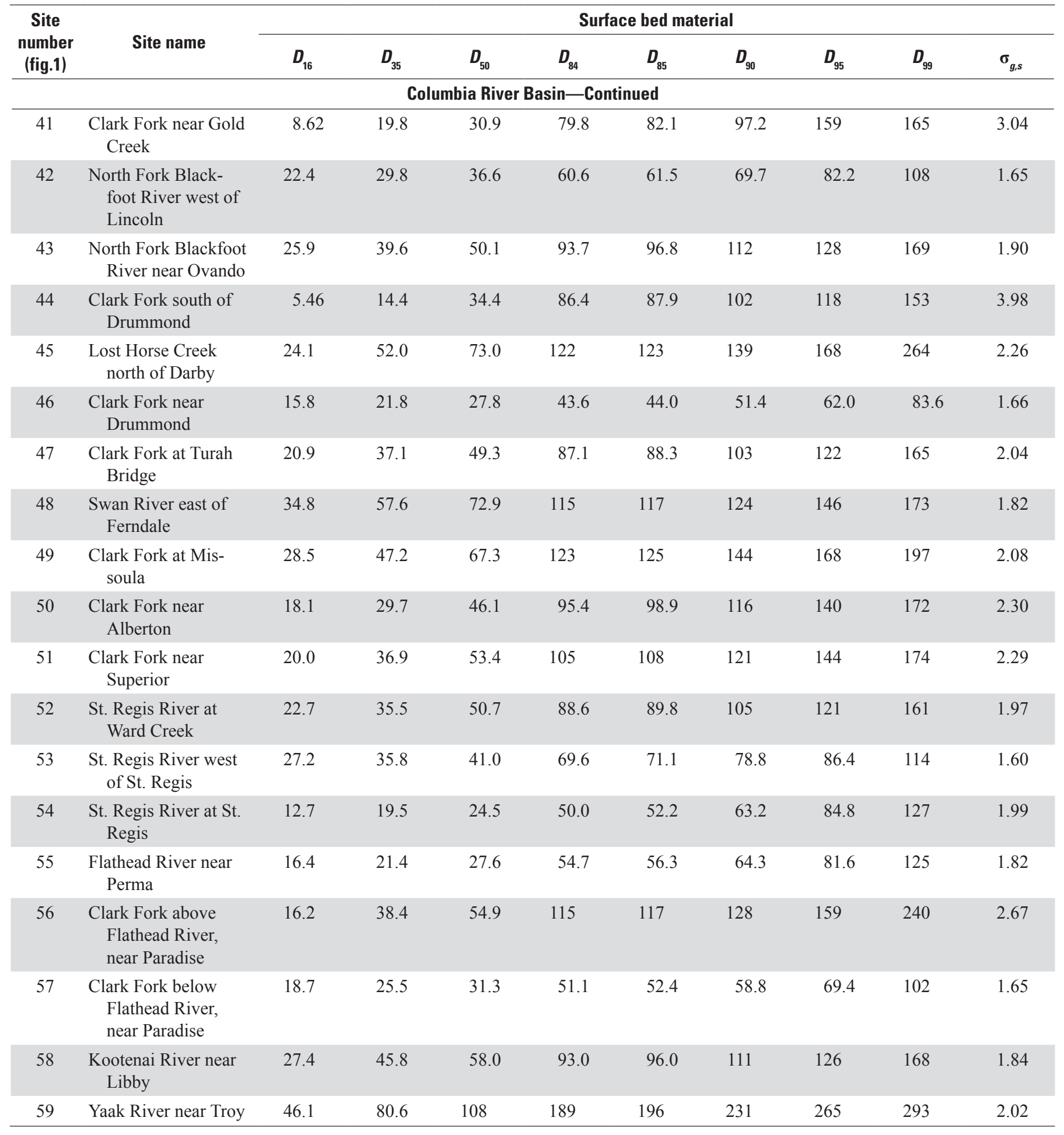

${ }^{1}$ The particle size of the shallow-subsurface bed material was estimated in the field to be essentially the same as the surface bed material. 


\begin{tabular}{|c|c|c|c|c|c|c|c|c|}
\hline \multicolumn{9}{|c|}{ Shallow-subsurface bed material } \\
\hline$D_{16}$ & $D_{35}$ & $D_{50}$ & $\boldsymbol{D}_{84}$ & $D_{85}$ & $D_{90}$ & $D_{95}$ & $D_{99}$ & $\sigma_{g, s s}$ \\
\hline \multicolumn{9}{|c|}{ Columbia River Basin-Continued } \\
\hline 1.92 & 17.5 & 31.5 & 72.2 & 73.3 & 78.8 & 84.4 & 88.9 & 6.13 \\
\hline 1.49 & 5.08 & 13.2 & 44.0 & 45.1 & 51.4 & 57.7 & 62.7 & 5.44 \\
\hline 3.30 & 10.7 & 18.5 & 61.9 & 63.9 & 72.6 & 81.3 & 88.3 & 4.33 \\
\hline 4.25 & 23.4 & 40.5 & 76.4 & 77.3 & 81.5 & 85.8 & 89.2 & 4.24 \\
\hline 3.20 & 20.8 & 33.7 & 62.2 & 62.9 & 70.8 & 80.4 & 88.1 & 4.41 \\
\hline 8.60 & 30.6 & 52.7 & 107 & 108 & 115 & 121 & 127 & 3.52 \\
\hline 4.09 & 18.9 & 36.0 & 136 & 138 & 152 & 166 & 177 & 5.76 \\
\hline 2.40 & 10.7 & 21.8 & 76.8 & 78.8 & 88.8 & 108 & 124 & 5.66 \\
\hline 5.31 & 21.0 & 52.3 & 97.1 & 99.1 & 109 & 118 & 126 & 4.27 \\
\hline 5.17 & 16.4 & 26.9 & 72.1 & 73.2 & 78.8 & 84.4 & 88.9 & 3.73 \\
\hline 5.95 & 20.8 & 39.1 & 77.6 & 78.3 & 82.2 & 86.1 & 89.2 & 3.61 \\
\hline 1.78 & 13.0 & 17.4 & 38.5 & 39.5 & 44.3 & 76.0 & 87.2 & 4.65 \\
\hline 12.1 & 36.0 & 66.4 & 86.8 & 87.4 & 92.4 & 110 & 124 & 2.68 \\
\hline 17.9 & 47.9 & 73.1 & 111 & 112 & 117 & 123 & 127 & 2.49 \\
\hline
\end{tabular}


effects, as cited in the section "Development of Pier-Scour Equations for Coarse-Bed Streams." Some of these improvements were based on laboratory studies and some were based on field studies. Many of the equations developed or improved based on laboratory studies are not able to successfully predict pier-scour depth in natural streams with highly variable bedmaterial characteristics. Even equations developed based on field data are not able to successfully predict pier scour under all field conditions. For example, the most recent (2011) HEC-18 equation (equation 5 ) incorporates a correction factor for coarse bed streams $\left(K_{4}\right) . K_{4}$ is calculated using a velocityintensity ratio (equation 10 ) that is dependent on the $D_{50}$ and $D_{95}$ particle sizes. Under most natural conditions, the $D_{95}$ moderately exceeds the $D_{50}$, the velocity-intensity ratio and $K_{4}$ can be calculated, and the resulting scour predictions are acceptable. Mueller and Jones (1999, p. 306) and Richardson and Davis (2001, p. 6.6) reported that the configuration of the denominator in equation 10 can produce anomalous results (negative velocity ratio) for rare combinations of $D_{50}$ and $D_{95}$. None of the surface bed-material particle-size data associated with pier-scour measurements collected for this study produced anomalous results when used in equation 10 . To better understand conditions where equation 10 produced anomalous results, selected pier-scour data collected for this study were used in equation 10 and manipulated (increased or decreased) until anomalous results were achieved. Anomalous results were produced when $D_{95}$ substantially exceeded $D_{50}$ and when $D_{95}$ was similar in magnitude to $D_{50}$ for certain $D_{50}$ and $D_{95}$ size combinations. Because the solution of equation 10 depends on $D_{95}$ being larger in some modest proportion to $D_{50}$, the surface bed-material data from this study were analyzed to statistically determine the relation between the $D_{50}$ and $D_{95}$ particle sizes based on regression analysis (Helsel and Hirsch, 2002) and evaluation of $r^{2}$ and $p$. The coefficient of determination $\left(r^{2}\right)$ has a value that ranges from 0 to 1 and the strength of the relation increases as the value of $r^{2}$ approaches 1 . The $p$-value is the probability of obtaining a result that is more extreme than a given value, where a $p$-value less than 0.05 indicates statistical significance (significance level) of the regression relation. Based on the regression analysis, the $D_{50}$ and $D_{95}$ particle sizes have a positive relation with each other that is statistically significant $\left(r^{2}=0.73\right.$ and $\left.p<0.001\right)$. In other words, for the data collected for this study, sites that have a larger $D_{50}$ particle size also tend to have a larger $D_{95}$ particle size. This observation is similar to the observation of Mueller and Jones (1999) about the bed-material data originally used to develop the equation for the $K_{4}$ correction factor.

Bed-material size is an important characteristic that determines the magnitude of the velocity required to cause pier scour. The effect of bed-material size on pier scour typically is investigated in conjunction with hydraulic characteristics like velocity and flow depth because these characteristics also influence the mobility of bed material. Relative velocity $\left(V_{o} / V_{c 50}\right)$ incorporates all three of these characteristics. Previous researchers have examined the relation between relative velocity and relative pier scour and formulated envelope curves. Melville (1984) and Chiew (1984) found the first peak in the envelope curve to be on the threshold between clearwater and live-bed scour $\left(V_{o} / V_{c 50}=1.00\right)$ and a second live-bed scour peak became asymptotic (approaching a constant value) with increasing relative velocity and live-bed scour conditions. They also showed that the magnitude of the second peak was less than the first peak for nonripple-forming sediments $\left(D_{50} \geq 0.6 \mathrm{~mm}\right)$, and the second peak was greater than the first peak for ripple-forming sediments $\left(D_{50}<0.6 \mathrm{~mm}\right)$.

The relation between relative pier scour and relative velocity defined by an envelope curve for the data collected for this study and the BSDMS Coarse dataset (fig. 14A) were compared to relations observed in laboratory data by Melville (1984) and Chiew (1984). The envelope curve for data used for this study displays an earlier peak with a decrease in relative pier scour followed by an asymptotic rise. Interestingly, the first peak (fig. 14A) in the curve occurs at a lower relative velocity $\left(V_{o} / V_{c 50} \approx 0.75\right)$ than the clear-water and live-bed threshold $\left(V_{o} / V_{c 50}=1.00\right)$. Also, the magnitude of relative pier scour (maximum of 1.25) is much less than the published value of 2.4 obtained from laboratory data for cylindrical piers (Melville and Sutherland, 1988). Furthermore, equilibrium live-bed scour is about 18 percent shallower than the maximum pier scour under clear-water conditions, a larger reduction than the 10 percent indicated by Richardson and Davis (1995, p. 16). Montana historical pier-scour data from 1996-97 (fig. 14A) plot below or on the envelope curve, indicating that the curve developed from scour data for flows approximating bankfull discharge $(\leq 2$-year recurrence interval) also envelopes data for more severe hydrologic and hydraulic conditions with recurrence intervals up to about 100 years (table 8 ).

As noted, the envelope curves that bound the pier-scour data collected for this study (fig. 14A), and in particular the magnitude of the maximum relative pier scour and the relative velocity associated with that maximum, were different than expected based on envelope-curve relations from previous studies. Some of these differences between data and relations from past studies and data and relations from this study could be mostly reflections of the paucity of data defining the $y_{s}^{\prime} / b$ maxima (fig. 14A), with the true maxima being slightly greater and corresponding relative velocity $\left(V_{o} / V_{c 50}\right)$ closer to the theoretical clear-water and live-bed scour threshold. However, differences in the bed-material characteristics and flow conditions between data collected for this study and earlier studies are a more likely explanation. First, the sizes of bed-material associated with pier-scour data collected for this study and included in the BSDMS Coarse dataset are much larger than bed-material sizes associated with pier-scour data from research (Melville and Sutherland, 1988) that documented higher maximum relative pier scour values approaching 2.4. Less pier scour would be expected at sites with coarser bed material and associated armoring. In addition, hydraulic conditions encountered in the field that cause scour of bed material at the pier typically involve variable streamflows over some duration (unsteady flow), compared to constant flow 

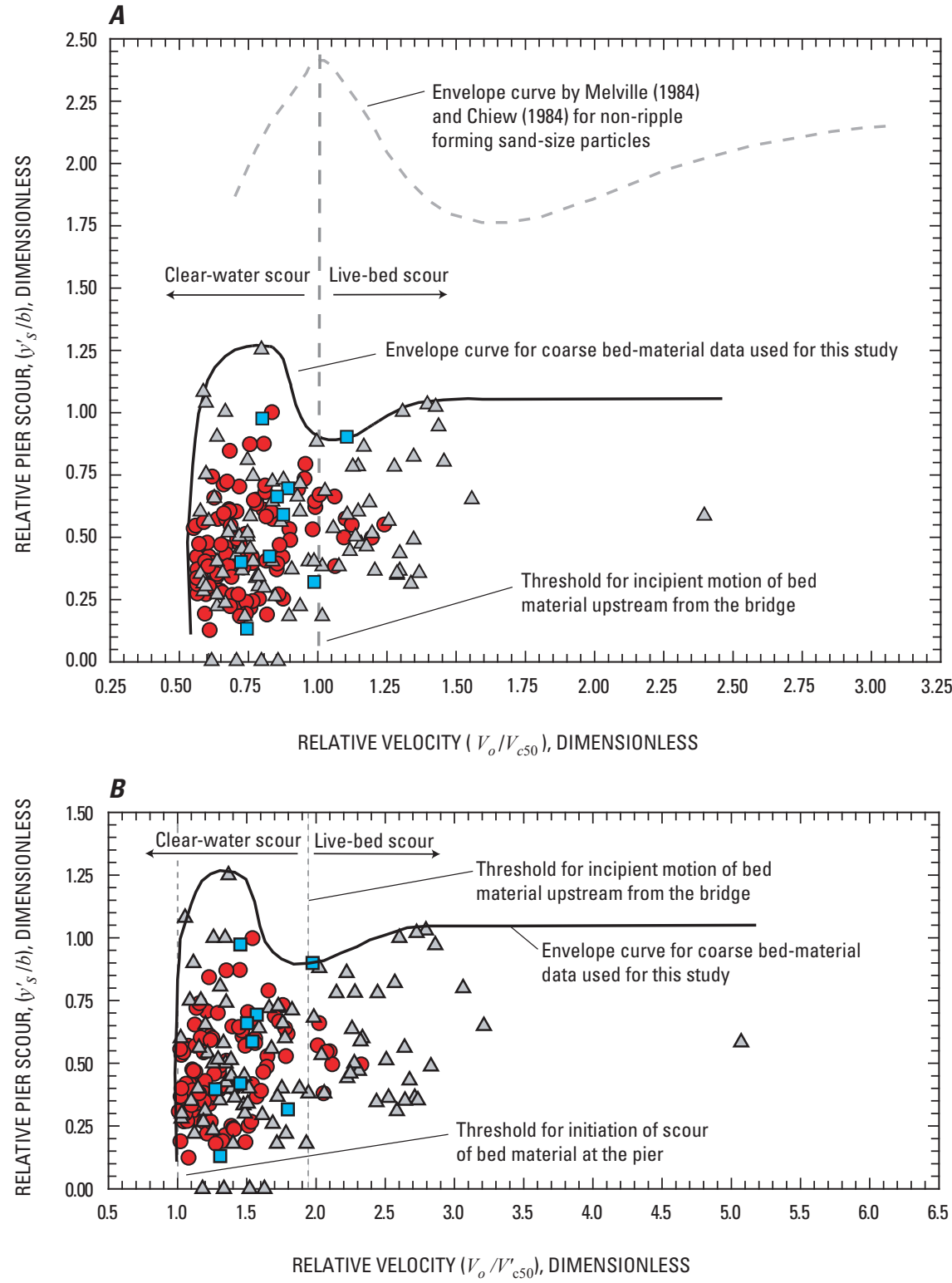

\section{EXPLANATION}

Data collected for this study ( $n=103)$

$\triangle$ Data from the Bridge Scour Data Management System (BSDMS) Coarse dataset $(n=90)$

口 Data for sites 60-62 for 1996-97 ( $n=9$ ) associated with peak streamflows of greater recurrence interval than data collected for this study

Variables

$n$ is the number of measurements

$y_{S}^{\prime}$ is pier-scour depth from field measurements, in feet

$b$ is the effective width of the pier measured perpendicular to the approach flow, in feet

$V_{O}$ is the approach velocity directly upstream from the pier, in feet per second

$V_{c 50}$ is the critical velocity for incipient motion of bed material upstream of the bridge for the $D_{50}$ particle size, in feet per second

$V_{c 50}^{\prime}$ is the critical velocity to initiate scour of bed material at the pier for the $D_{50}$ particle size, in feet per second

Figure 14. Relation between relative pier scour and: $A$, relative velocity based on critical velocity for incipient motion of bed material upstream from the bridge; and $B$, relative velocity based on critical velocity to initiate scour of bed material at the pier.

conditions over a duration (steady flow) typically used in the laboratory. Raudkivi and Sutherland (1981) investigated the effects that steady and unsteady flow conditions and flow duration had on the relation between pier scour and relative velocity in the laboratory. They found that pier scour attained under unsteady-flow conditions was only about 50 to 70 percent of pier scour attained under steady-flow conditions. Mueller (1996) made the observation based on the work of Raudkivi and Sutherland (1981) that the nearer the relative velocity of the flood peak is to the threshold for live-bed conditions and the longer the duration of the flood wave, the nearer the scour depth approaches the steady-state scour depth corresponding to the peak discharge. The magnitude of relative pier scour values for data collected for this study and from the BSDMS Coarse dataset (fig. 14A) reflects unsteady-flow conditions with peak flows of limited duration and is, therefore, consistent with findings of past research (Raudkivi and Sutherland, 1981; Mueller, 1996, p. 70-72). Armoring associated with nonuniform coarse-bed material and unsteady-flow conditions in the field probably account for differences between envelope curves developed for this study and those from previous studies conducted in the laboratory using fine-grained material and steady-flow conditions.

The very coarse nature of the bed material associated with pier-scour data collected for this study and in the BSDMS Coarse dataset most likely also contributed to the narrow 
range of relative velocity $\left(V_{o} / V_{c 50}\right)$ ratios (about 0.55 to 1.55 , with one value near 2.4, fig. 14A). Finer sediment has been shown (Chiew, 1984) to produce a wider range of $V_{o} / V_{c 50}$ ratios (about 0.5 to 5.0). The prevalence of clear-water conditions associated with pier-scour measurements collected for this study indicates that the critical velocity to initiate scour of bed material at the pier $\left(V_{c 50}^{\prime}\right.$, equation 2$)$ might be used in place of the critical velocity for incipient motion of bed material upstream from the bridge $\left(V_{c 50}\right)$ for demonstrating relations between relative pier scour and relative velocity. Replacing $V_{o} / V_{c 50}$ with $V_{o} / V_{c 50}^{\prime}$ as a measure of velocity intensity for pier scour (fig. 14B) produces similar results (fig. 14A), but in addition, shows that maximum relative pier scour (as measured by $\left.y_{s}^{\prime} / b\right)$ occurs when the approach velocity $\left(V_{o}\right)$ is about 1.3 to 1.4 times the critical velocity to initiate scour of bed material at the pier $\left(V_{c 50}^{\prime}\right)$. If the approach velocity increases beyond that point, relative pier scour decreases until approach velocity reaches a minimum of about 1.8 to 1.9 times $V_{c 50}^{\prime}$, then increases asymptotically to reach equilibrium scour under live-bed conditions.

The threshold for incipient motion of the streambed that defines the boundary between clear-water and live-bed scour conditions $\left(V_{o} / V_{c 50}=1.00\right)$ in figure $14 B$ was determined by regression analysis of corresponding pairs of $V_{o} / V_{c 50}$ and $V_{o} / V_{c 50}^{\prime}$ ratios computed from the pier-scour data collected for this study and the BSDMS Coarse dataset. The resulting regression equation was used to compute the ratio of $V_{o} / V^{\prime}{ }_{c 50}$ that statistically corresponded to $V_{o} / V_{c 50}=1.00$, the boundary between clear-water and live-bed scour conditions. Based on data collected for this study and the BSDMS Coarse dataset, the relative velocity associated with the threshold between clear-water and live-bed scour conditions is 1.94 times the relative velocity associated with initiation of scour at the pier $\left(V_{o} / V_{c 50}^{\prime}\right)$.

In addition to surface bed-material size, previous studies showed that surface bed-material gradation also affected pier-scour depth. According to Ettema (1976), when gradation coefficients $\left(\sigma_{g}\right)$ are more than about 1.4 to 1.5 , scour holes can become armored limiting further pier scour. Gradation coefficients associated with surface bed-material data collected for this study ranged from 1.48 to 4.14 , with a median of 2.01 (table 5). Bed-material gradation associated with pier-scour measurements collected for this study was less variable than bed-material gradation associated with pier-scour data in the BSDMS Coarse dataset (fig. 15), and bed-material gradation for all the pier-scour measurements collected for this study was sufficient for streambed armoring.

The effect of surface bed-material gradation on pier scour was assessed as part of this study by relating the gradation coefficient $\left(\sigma_{g}\right)$ to relative pier scour (fig. 16), similar to Mueller and Wagner (2005). Ripple-forming (fine) sediments $\left(D_{50}<0.6 \mathrm{~mm}\right)$ and nonripple-forming (coarser) sediments $\left(D_{50} \geq 0.6 \mathrm{~mm}\right)$ each have different relations, but the maximum relative pier scour for both kinds of sediments is concentrated near a value of $\sigma_{g}$ between about 2.0 and 2.5. After reaching a maximum value, relative pier scour decreases as $\sigma_{g}$ increases. Relative pier scour is greater for ripple-forming sediments when the gradation coefficient is less than about 2.5 , except

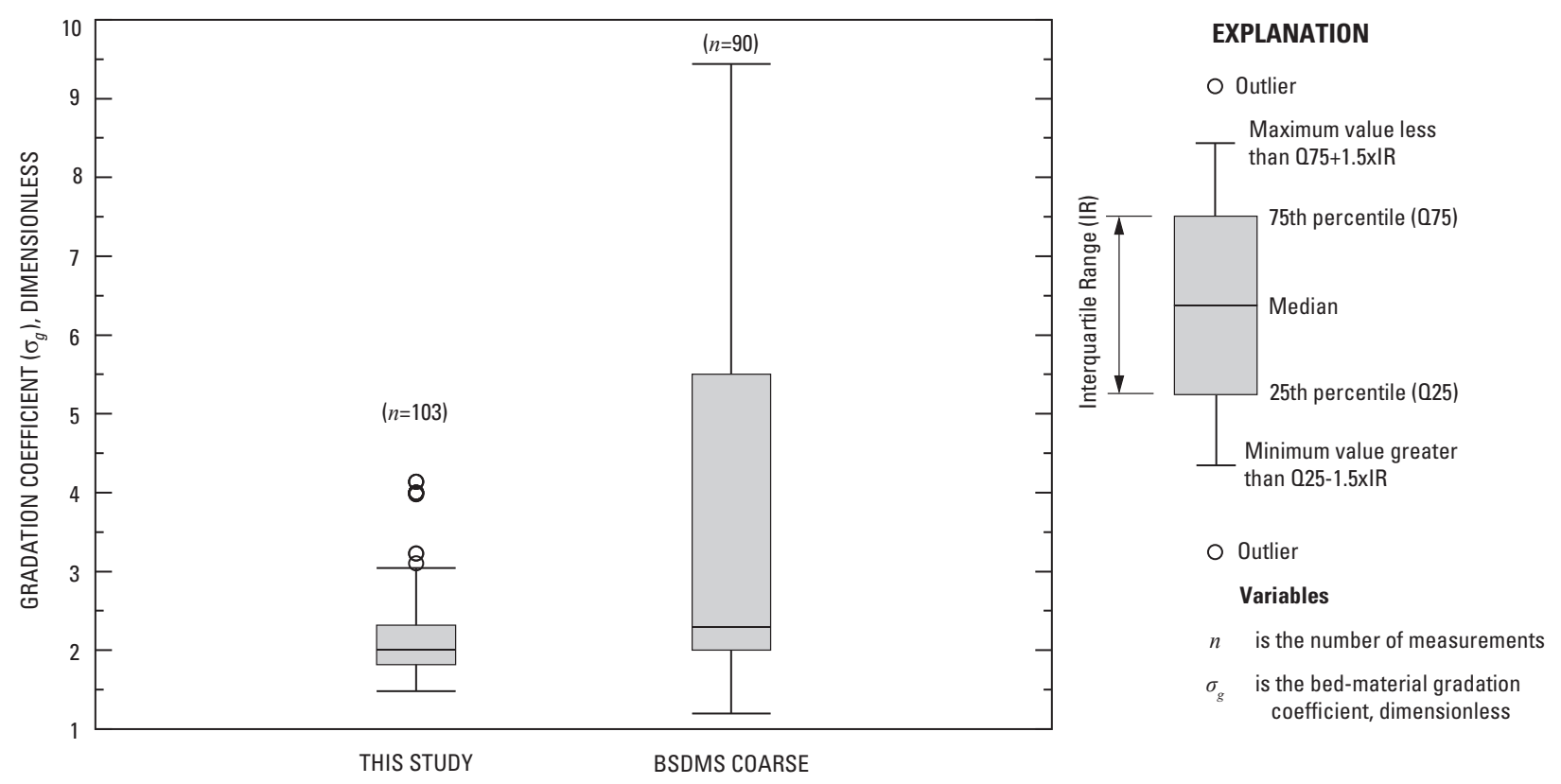

Figure 15. Comparison of gradation coefficient for surface bed material for pier-scour measurements collected for this study with the Bridge Scour Data Management System (BSDMS) Coarse dataset. 
perhaps for small gradation coefficients (less than about 1.3) where the envelope curves are poorly defined. Relative pier-scour for ripple-forming sediments reaches a maximum when the gradation coefficient is slightly less than or about the same magnitude as for nonripple-forming sediments, but the envelope curve for ripple-forming sediments $(n=88)$ declines more sharply with increasing gradation coefficient compared to the envelope curve for the nonripple-forming sediments ( $n=184)$. Maximum relative pier-scour is substantially less for nonripple-forming sediments from this study because the bed material was much coarser compared to the BSDMS nonripple-forming sediment data. The envelope-curve decline rate associated with data from this study is not compared to the BSDMS envelope-curve decline rates because data from this study having gradation coefficients greater than about 4.0 are lacking. Mueller and Wagner (2005) noted that the larger reduction in relative pier scour for ripple-forming sediments having more gradation may be due to armoring caused by the coarser sediment fractions. The average median particle size $\left(\bar{D}_{50}\right)$ for data points defining each of the three curves (fig. 16) also indicates that maximum relative pier scour decreases with an increase in bed-material size.

Gradation effects also were investigated by using $\sigma_{g}$ as a grouping variable when relating relative pier scour to relative velocity. Scour data were grouped into selected $\sigma_{g}$ intervals, and the average $\sigma_{g}$ value within an interval was used to define each group. No obvious relation was observed between relative pier scour and relative velocity for any of the $\sigma_{g}$ intervals when the data were plotted, which is consistent with the conclusion of Mueller and Wagner (2005). However, Ettema (1980) showed that relative pier scour for $\sigma_{g}>2.5$ is reduced for both ripple- and nonripple-forming sediments. Based on that observation, data collected for this study and the BSDMS Coarse dataset were grouped by $\sigma_{g}$, and two envelope curves were hand drawn (fig. 17A) that distinguish between $\sigma_{g} \leq 2.5$ and $\sigma_{g}>2.5$. As shown by Ettema (1980) for data collected for this study and the BSDMS Coarse dataset, maximum relative pier scour is greater when $\sigma_{g} \leq 2.5$.

Relations between relative pier scour, relative velocity, and gradation coefficient also were investigated using the critical velocity to initiate scour of bed material at the pier $\left(V_{c 50}^{\prime}\right)$ in place of the critical velocity for incipient motion of bed material upstream from the bridge $\left(V_{c 50}\right)$ to define relative velocity (fig. 17B). With relative velocity expressed as $V_{o} / V_{c 50}^{\prime}$, differences in maximum relative pier scour between the two envelope curves (fig. 17B) that distinguish between $\sigma_{g} \leq 2.5$ and $\sigma_{g}>2.5$ are the same as before (fig. 17A), but the maxima demonstrate better symmetry with each other and are located at about 1.2 to 1.4 times the relative velocity defined by $V_{o} / V_{c 50}^{\prime}$. The threshold for incipient motion of bed material upstream from the bridge that defines the boundary between clear-water and live-bed scour conditions for each envelope curve in figure $17 B$ was determined by regression using corresponding ratios of $V_{o} / V_{c 50}$ and $V_{o} / V_{c 50}^{\prime}$ computed from pierscour measurements collected for this study and the BSDMS Coarse dataset. The resulting regression equation was used to compute the ratio of $V_{o} / V_{c 50}^{\prime}$ that statistically corresponded to $V_{o} / V_{c 50}=1.00$ for each envelope curve. Based on data from

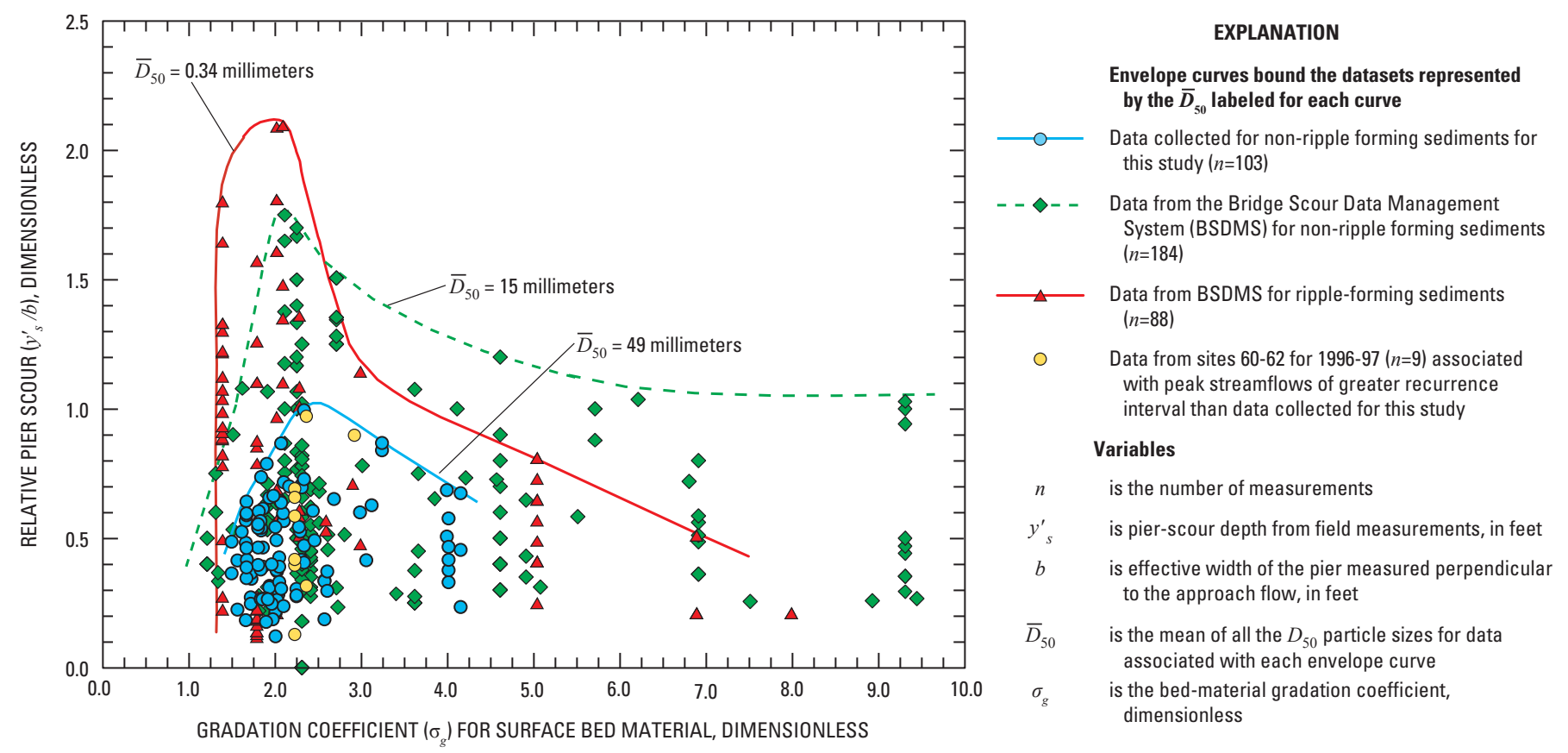

Figure 16. Relation between relative pier scour and gradation coefficient for pier-scour measurements collected for this study, historical pier-scour data from Montana, and pier-scour measurements in the Bridge Scour Data Management System (BSDMS) All dataset in ripple-forming $\left(D_{50}<0.6\right.$ millimeter $)$ and nonripple-forming $\left(D_{50} \geq 0.6\right.$ millimeter $)$ sediments. 


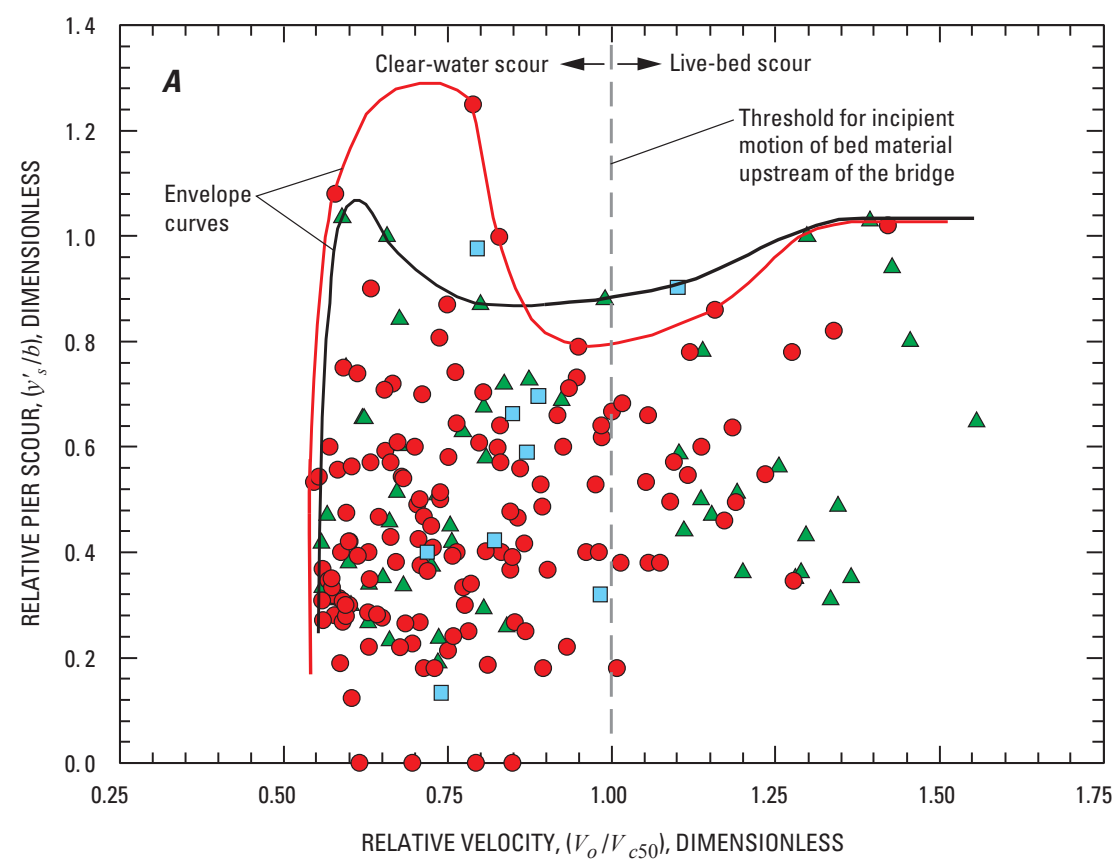

EXPLANATION

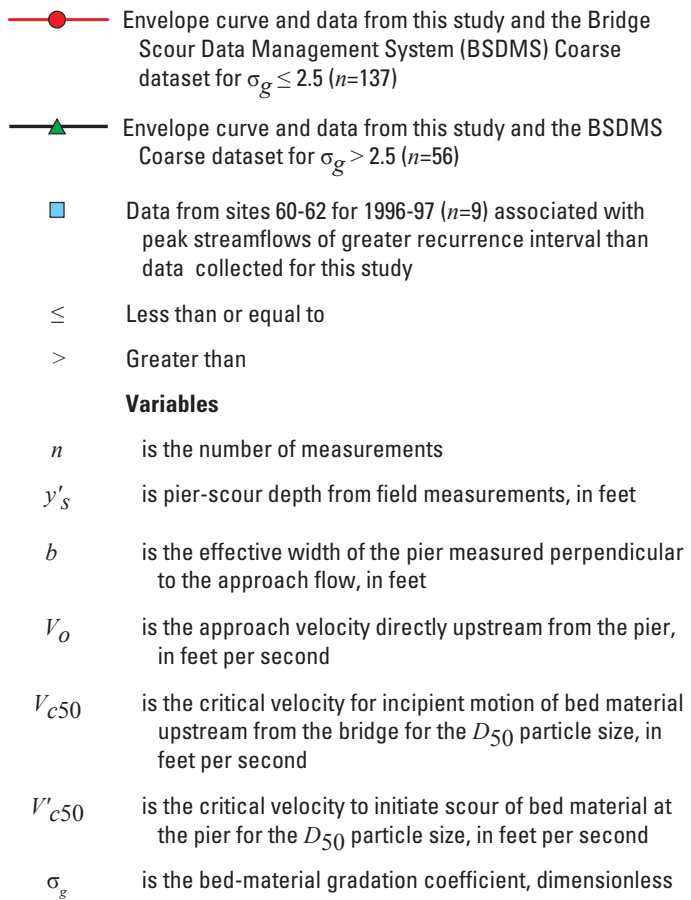

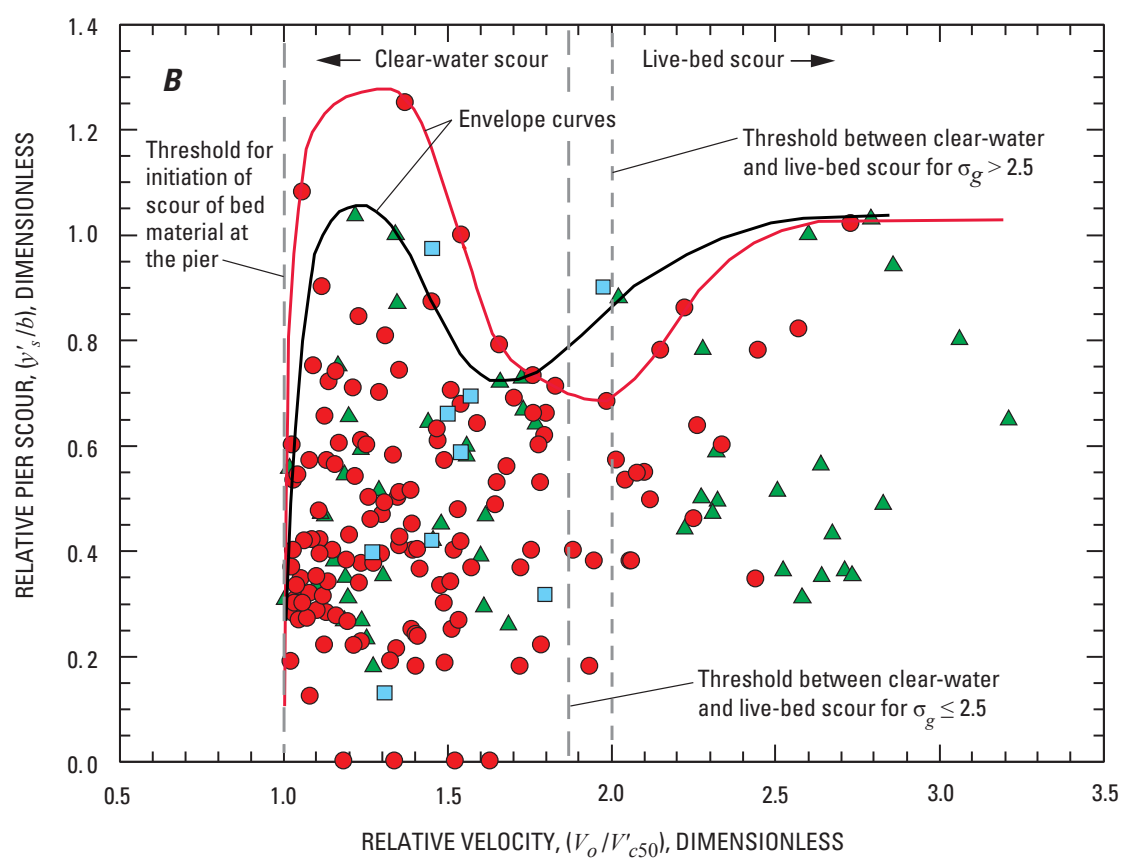

Figure 17. Relation between relative pier scour and: $A$, relative velocity based on critical velocity for incipient motion of bed material upstream from the bridge; and $B$, relative velocity based on critical velocity to initiate scour of bed material at the pier. 
this study and the BSDMS Coarse dataset, the relative velocity associated with the threshold between clear-water and live-bed scour conditions is 1.88 times the relative velocity associated with initiation of scour at the pier when $\sigma_{g} \leq 2.5\left(r^{2}=0.98\right.$ and $p<0.001)$, and is 2.00 times the relative velocity associated with initiation of scour at the pier when $\sigma_{g}>2.5\left(r^{2}=0.99\right.$ and $p<0.001)$. Coarse-bed material with a larger gradation coefficient $\left(\sigma_{g}>2.5\right)$ attains live-bed conditions at a higher relative velocity, compared to similar coarse-bed material with a smaller gradation coefficient $\left(\sigma_{g} \leq 2.5\right)$. This observation is consistent with previous studies (Chiew, 1984 and Baker, 1986) that noted the tendency for well-graded bed material to armor at lower relative velocities and resist further scour. Similarities in the magnitude of maximum relative scour for the envelope curve (fig. 17B) associated with larger gradation coefficients $\left(\sigma_{g}>2.5\right)$ also may indicate that distinctions between clear-water and live-bed scour may not be important when surface bed material is coarse and well graded $\left(\sigma_{g}>2.5\right)$.

Comparison of the two envelope curves indicates that a relation between relative pier scour and relative velocity that depends on $\sigma_{g}$ may exist under field conditions but less conclusively than was indicated in laboratory research (Baker, 1986), where $D_{50}$ was held constant while the size of the coarser fraction of the sediments was increased. A lack of field data for ripple-forming sediments with large gradation coefficients indicates that surface bed material having this characteristic may not be commonly found in natural streams.

Pier-scour measurements collected for this study and the BSDMS All dataset confirm a general lack of data for coarsebed sites with $\sigma_{g}$ greater than about 2.5 (figs. 15 and 16). Grouping these data by size classification based on the $D_{50}$ of the bed material also illustrates the lack of data for coarse-bed sites with $\sigma_{g}$ greater than 2.5 (table 10). The percentage of scour data from sites $(n=375)$ with coarse-bed material (larger than sand, table 10 ) having $\sigma_{g}$ greater than 2.5 is only 8 percent of the data. Furthermore, only 15 percent of scour data from sites with bed material classified as sand (table 10) have gradation coefficients exceeding 2.5. Mueller and Wagner (2005) found that the small number of sites with ripple-forming sediments with larger gradation coefficients made it difficult to draw conclusions on the effect of gradation on scour. Similarly, the relatively small amount of pier-scour data from sites with coarse bed material and large gradation coefficients makes it difficult to understand the effects of gradation under these conditions. The narrow range in gradation coefficients displayed by all available data and the nonuniform conditions present in the field continue to complicate efforts to isolate the effects of gradation on pier scour.
Table 10. Percentage of pier-scour measurements ${ }^{1}$ with a gradation coefficient greater than 2.5 .

[Abbreviations: BSDMS, Bridge Scour Data Management System. Symbols: $\sigma_{g}$, gradation coefficient, dimensionless; >, greater than; $K_{4}$, correction factor for bed-material armoring effect; $n$, number of data values in dataset]

\begin{tabular}{lc}
\hline $\begin{array}{c}\text { Description class for } \\
\text { surface bed material }\end{array}$ & $\begin{array}{c}\text { Percent of data }^{\mathbf{3}} \\
\text { with } \boldsymbol{\sigma}_{\boldsymbol{g}} \mathbf{>} \mathbf{2 . 5}\end{array}$ \\
\hline Small cobble & 1 \\
Very coarse gravel & 2 \\
Coarse gravel & 3 \\
Medium gravel & 2 \\
Fine to very fine gravel & 0 \\
Sand & 15 \\
\hline
\end{tabular}

${ }^{1}$ Includes all pier-scour measurements collected for this study $(n=103)$ and BSDMS All dataset $(n=272)$ used in comparisons that meet HEC-18 criteria (Richardson and Davis, 2001) for applying $K_{4}$.

${ }^{2}$ Surface bed material classified based on the $D_{50}$ particle size.

${ }^{3}$ Number of observations within a description class (with $\sigma_{g}>2.5$ ) divided by the total number of data $(n=375)^{g}$, expressed as a percent.

\section{Effects of Shallow-Subsurface Bed-Material Characteristics}

Since the mid-1960s, pier-scour researchers have considered the effects of bed-material characteristics on pier scour as cited in the section "Development of Pier-Scour Equations for Coarse-Bed Streams." That research focused primarily on surface bed material because vertical variations in bedmaterial characteristics were not a concern in flume studies where the experimental bed material was composed of either uniform particles or a nonuniform mixture of sediment with the same size and gradation characteristics throughout the thickness of the bed. While collecting coarse-bed pier-scour data in the field for this study, differences were observed in surface and shallow-subsurface bed-material size and gradation (fig. 4). As a result, bed-material samples for both the surface and shallow-subsurface layers were collected and analyzed (table 9). The particle-size distribution and gradation 
for the bed-material samples for each layer were compared and the differences in particle size that might relate to armoring were described by using ratios of the particle sizes for each layer. Differences in particle size and gradation between the two layers were apparent (table 9). Therefore, the effect these differences might have on pier-scour computations was investigated.

Particle-size distribution curves for paired samples of surface and shallow-subsurface bed material collected for this study were analyzed and the $D_{50}$ and $D_{95}$ particle sizes were compared. The difference between the surface and shallowsubsurface bed-material $D_{50}$ and $D_{95}$ particle sizes (fig. 18) confirmed what was observed in the field - due to armoring, larger particles were more commonly found on the streambed surface than in the shallow subsurface (fig. 4). However, coarse particles still made up a substantial portion of the shallowsubsurface bed material at most sites. Median $D_{50}$ particle sizes for 103 surface and shallow-subsurface bed-material samples were about $49 \mathrm{~mm}$ and $32 \mathrm{~mm}$, respectively, and median $D_{95}$ particle sizes for 103 surface and shallow-subsurface bed material samples were $122 \mathrm{~mm}$ and $86 \mathrm{~mm}$, respectively (fig. 18, table 5). These differences may result in reduced pier scour because bed-material size has been shown in this (figs. 6 and 11) and other studies cited in the section "Development of Pier-Scour Equations for Coarse-Bed Streams" to be inversely related to pier-scour depth.
Differences in gradation between surface and shallowsubsurface bed-material samples also were examined for this study. The median gradation coefficients for surface and shallow-subsurface bed material associated with measurements made for this study were 2.01 and 4.14, respectively (fig. 19 and table 5). The median gradation coefficient of the shallowsubsurface bed material was about twice that of the surface bed material (fig. 19) owing to the presence of finer-grained sediment in the shallow-subsurface bed material. These differences in gradation coefficient may result in reduced pier scour because gradation coefficients have been shown in this (figs. 16 and 17) and other studies cited in the section "Development of Pier-Scour Equations for Coarse-Bed Streams" to be inversely related to pier-scour depth in coarse-bed streams like those where pier-scour measurements were collected for this study. The combined effect of the larger surface bedmaterial size, relative to shallow-subsurface bed-material size, and the wider range of gradation coefficients in shallowsubsurface bed material is typical for the pier-scour measurements made for this study and may contribute to reduced pier scour in these coarse-bed streams. Differences in particle size and gradation coefficient between the two bed-material layers are likely similar to the variability in particle size and gradation coefficient that might be observed between multiple sets of pebble counts conducted to quantify average surface bedmaterial characteristics. This variability has been recognized

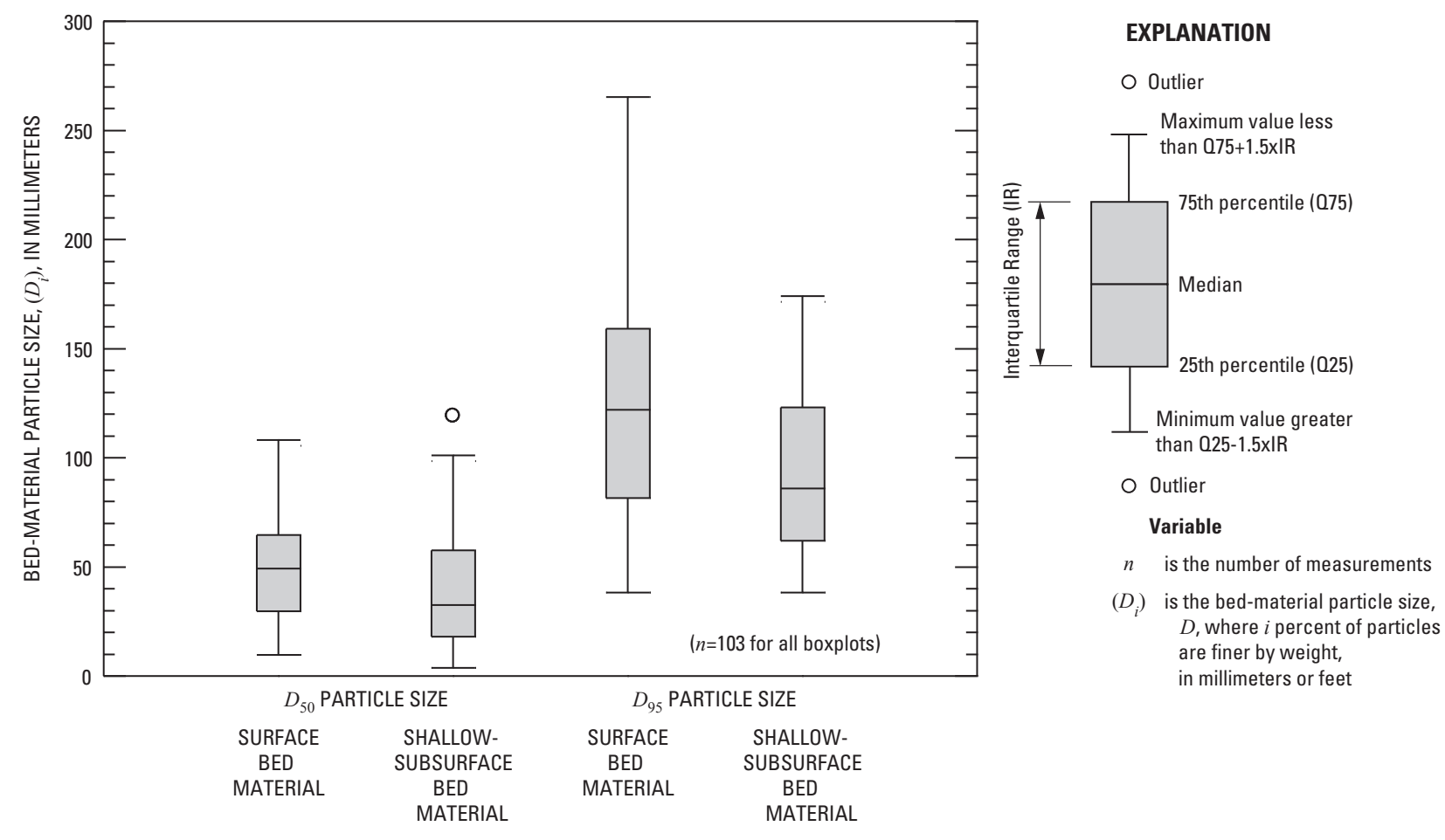

Figure 18. Comparison of surface and shallow-subsurface bed-material particle size for pier-scour measurements collected for this study. 


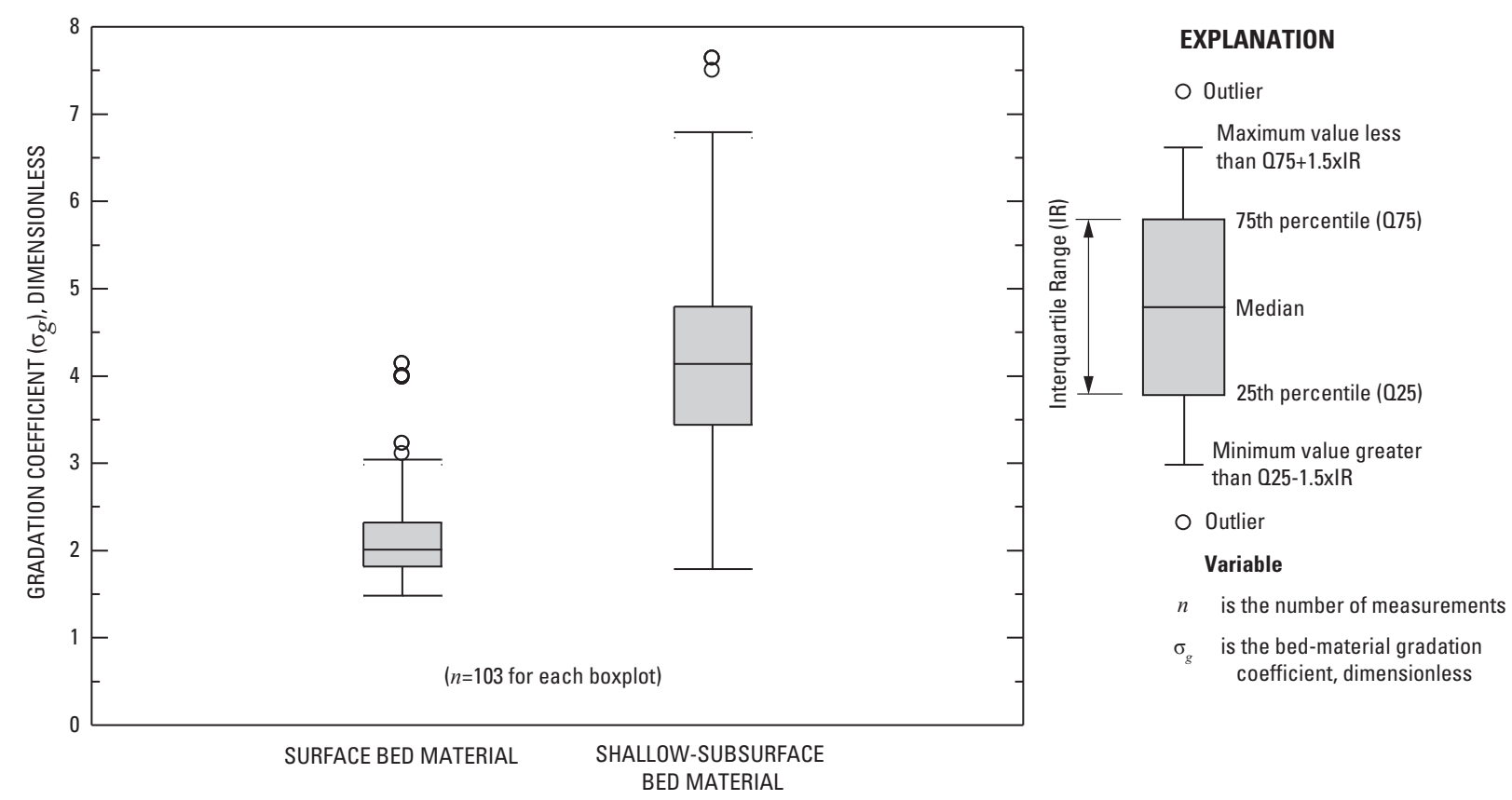

Figure 19. Comparison of surface with shallow-subsurface bed-material gradation coefficients for pier-scour measurements collected for this study.

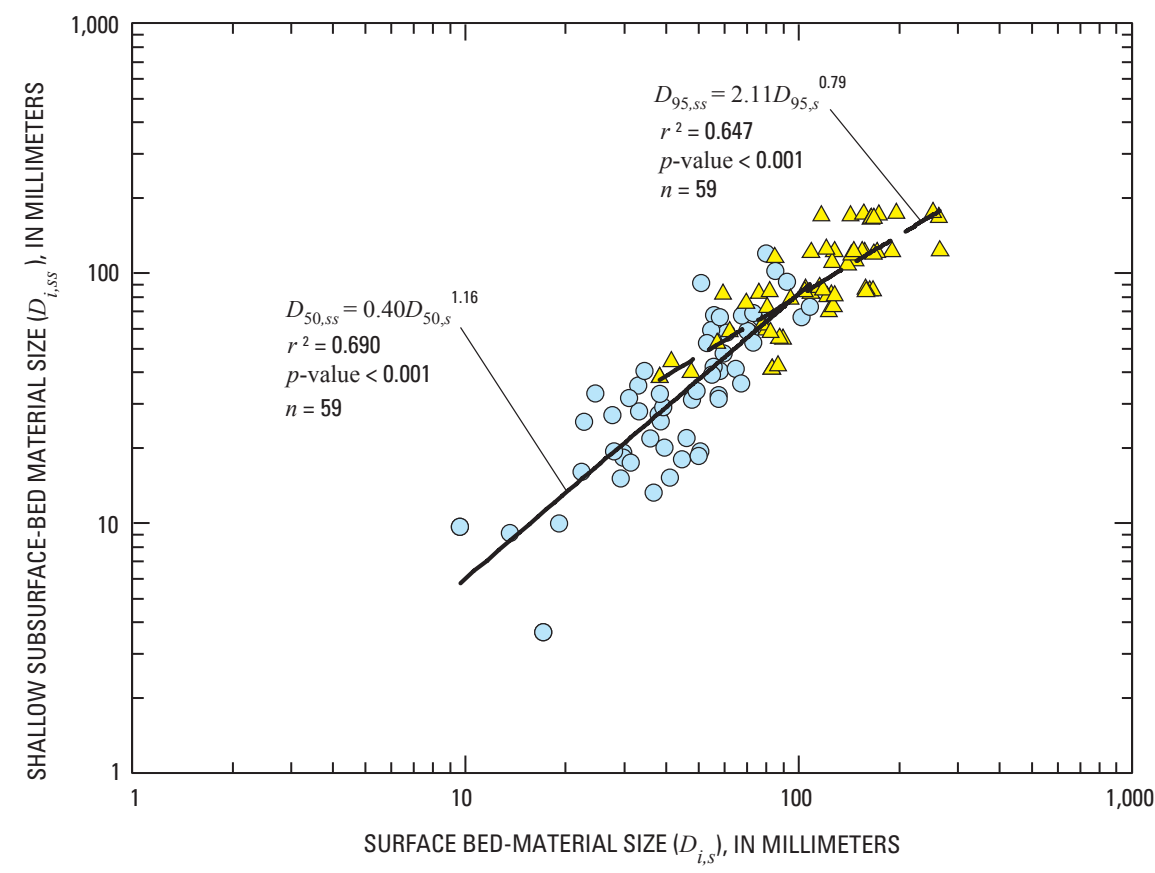

\section{EXPLANATION}

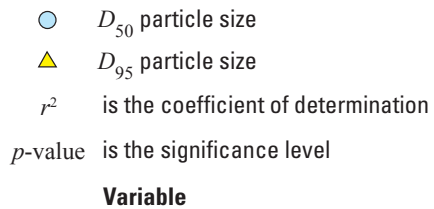
$i$ percent of particles are finer by weight, in millimeters or feet

$D_{(i, s s)}$ is the shallow-subsurface bed-material particle size, $D$, where $i$ percent of particles are finer by weight, in millimeters or feet

Figure 20. Relations between corresponding surface and shallow-subsurface bed-material particle size $\left(D_{50}\right.$ and $\left.D_{95}\right)$ for pier-scour measurements collected for this study. 
as a potential source of uncertainty in accurate prediction of pier-scour depth (Mueller and Wagner, 2005, p. 61).

The relation between selected particle sizes of the two layers, independent of site location or specific particle size, was investigated using regression analysis of paired values of particle sizes for the surface and shallow-subsurface bedmaterial data collected for this study (fig. 20). A significant relation was indicated between surface and shallow-subsurface bed-material size for the $D_{50}$ and $D_{95}$ particle sizes (for $D_{50}$, $r^{2}=0.690$ and $p<0.001$; for $D_{95}, r^{2}=0.647$ and $p<0.001$ ). In other words, as the particles in the surface bed material increase in size, the particles in the shallow-subsurface bed material also tend to increase in size.

Recognizing that armoring is a process that commonly leads to reduced scour in coarse-bed streams, a previously published concept relating to armoring was used to further evaluate variations in particle size between surface and shallow-subsurface bed material. Lisle and Madej (1992, p. 277) proposed the ratio of surface-to-subsurface bedmaterial particle sizes as a measure of armoring. The variation in bed-material size over a selected range of the particle-size distribution curve ( $D_{16}$ to $D_{99}$ ) was, therefore, computed for the surface and shallow-subsurface bed material associated with the pier-scour data collected for this study using the equation:

$$
R_{i}=\frac{D_{i, s}}{D_{i, s s}}
$$

where

$$
\begin{aligned}
& R_{i} \quad \text { is the bed-material size ratio of the } \\
& D_{i, s} \quad \text { is the surface bed-material particle size, } D \text {, }
\end{aligned}
$$

Bed-material size ratios (median values for $R_{i}$ ) for the coarser portion of the particle-size distribution curve $\left(D_{50}\right.$ to $D_{99}$ ) did not vary substantially, and ranged from about 1.1 to 1.4 (fig. 21). The interquartile ranges (IR) also did not vary substantially and were all less than 1 . Bed-material size ratios (median values for $R_{i}$ ) for the finer portion of the particle-size distribution curve $\left(D_{16}\right.$ to $D_{35}$ ) were more variable than for bed-material size ratios for the coarser portion of the curve, and ranged from about 1.8 to about 4.0. The interquartile ranges also were more variable and ranged from about 1.2 to about 4.6. Thus, the greatest variability between surface and shallow-subsurface particle sizes, as defined by $R_{i}$, is at the fine-grained end of the particle-size distribution curve.

The streambed upstream from the bridge likely was armored at most measurement sites because the surface bed material was more coarse when compared to the shallowsubsurface bed material, and because of predominant
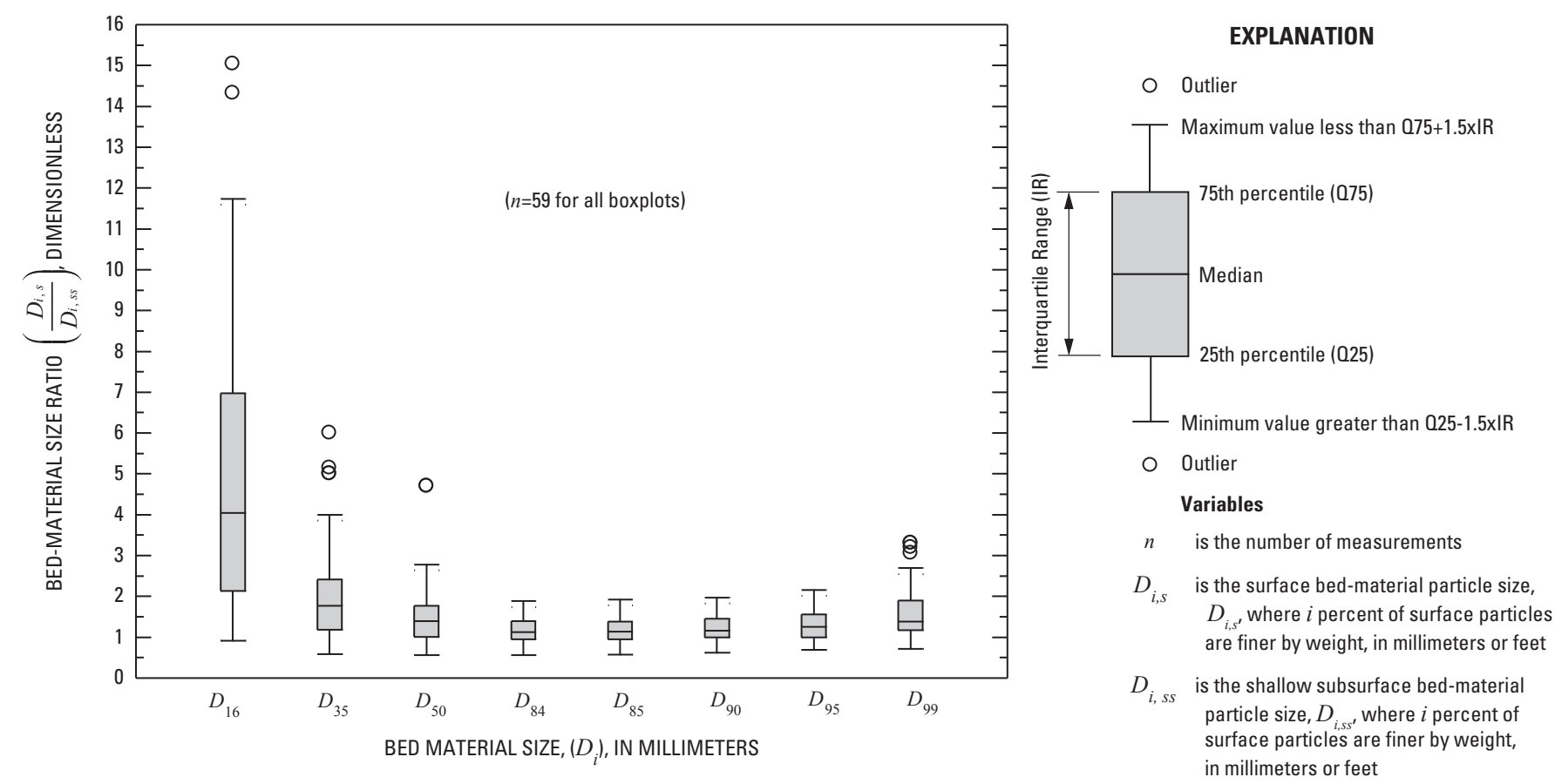

Figure 21. Comparison of ratios of surface to shallow-subsurface bed-material particle size based on selected percentiles $\left(D_{i}\right)$ from the particle-size distribution curves for each site where pier-scour measurements were collected for this study. 
clear-water conditions $\left(V_{o}<V_{c 50}\right)$ and gradation coefficients greater than 1.4 (table 9). At the piers, the relative scour velocities (fig. 8) were great enough $\left(V_{o} / V_{c 50}^{\prime}>1.00\right)$ that the armor layers in the scour holes were mobilized and all sites were undergoing pier scour. Based on observed field conditions, and the relative coarseness of the bed-material particle sizes for the two layers (figs. 20 and 21), $D_{50}$ and $D_{95}$ particlesize data for the shallow-subsurface bed material underlying the armor layer (table 9) also were used to compute pier scour by the HEC-18- $K_{4} \mathrm{Mu}$ equation (equation 5 ) with $K_{4}$ determined by equation 11 .

Scour depths were computed using the $D_{50}$ and $D_{95}$ shallow-subsurface particle-size data for 94 of the 103 pier-scour measurements made for this study. Nine of the measurements either did not meet the criteria to be considered as a valid real-time scour measurement, or anomalous results were produced when the $D_{50}$ and $D_{95}$ shallow-subsurface bed-material particle sizes were used in equation 11 to compute $K_{4}$. Scour depths computed based on shallow-subsurface particle sizes were then compared to both measured scour depths (table 2) and scour depths computed based on the surface bed-material particle-size data $\left(D_{50}\right.$ and $D_{95}$, table 9). Differences in $D_{50}$ and $D_{95}$ particle size between the surface and shallow-subsurface bed material did not cause substantial differences in computed scour (table 11). The frequency and magnitude of the residual pier-scour depth (fig. 22) associated with underpredicted and overpredicted scour was about the same regardless of which particle-size data were used with the HEC- $18-K_{4} \mathrm{Mu}$ equation. Computed scour was underpredicted in only 5 out of 94 instances when surface bed-material particle-size data were used with the HEC-18- $K_{4} \mathrm{Mu}$ equation and in only 3 out of 94 instances when shallow-subsurface bed-material particlesize data were used. Positive (underpredicted) and negative (overpredicted) residuals of scour are noted as separate statistics in table 11 because of the implication each type of residual separately has to bridge foundation design. The median underpredicted (positive) residual scour using surface and shallowsubsurface data with the HEC-18- $K_{4} \mathrm{Mu}$ equation (table 11) was 0.34 and $0.29 \mathrm{ft}$, respectively, and the maximum underpredicted residual scour was 0.52 and $0.34 \mathrm{ft}$, respectively. The median overpredicted (negative) residual scour using surface and shallow-subsurface data with the HEC-18- $K_{4} \mathrm{Mu}$ equation (table 11 ) was -0.91 and $-1.02 \mathrm{ft}$, respectively, and the greatest overpredicted residual scour was $-4.41 \mathrm{ft}$ using either bedmaterial layer.

Computed scour generally was the same or slightly greater when shallow-subsurface bed-material particle-size data were used with the HEC-18- $K_{4} \mathrm{Mu}$ equation because shallow-subsurface bed-material particle sizes $\left(D_{50}\right.$ and $\left.D_{95}\right)$ typically were slightly smaller than corresponding surface bedmaterial particle sizes. In addition, other factors contributed to the close agreement between pier-scour computations using the surface and shallow-subsurface bed-material size data. For example, of the 94 measurements made for this study satisfying criteria for real-time scour at the pier $\left(V_{o} / V_{c 50}^{\prime}>1.00\right), 37$ had computed values of $K_{4}$ less than 0.4 , regardless of whether surface or shallow-subsurface bed-material data were used with equation 11. The minimum allowed value of $K_{4}(0.4)$ was substituted for the computed $K_{4}$ in both instances according to HEC-18 criteria (Richardson and Davis, 2001). This substitution resulted in identical computed scour depths for these measurements, regardless of which bed-material data were used. Furthermore, 34 of 94 measurements had both computed values of $K_{4}$ exceeding 0.4 for surface and shallow-subsurface bed-material data - the median difference in computed $K_{4}$ was 0.03 . In addition, 21 of 94 measurements had at least one computed value of $K_{4}$ exceeding 0.4 when either surface or shallow-subsurface bed-material data were used with equation 11 - the median difference in computed $K_{4}$ was 0.05 after substituting 0.4 for the calculated $K_{4}$ that was less than 0.4 .

Finally, substantial differences for the computed Mueller velocity-intensity ratio $\left(V_{R M}\right.$, equation 10$)$ for some sites typically resulted in much smaller differences between the resulting values of $K_{4}$ computed by equation 11 using corresponding surface and shallow-subsurface data. The modest response of $K_{4}$ (dependent variable) to more widely varying values of $V_{R M}$ (independent variable) is partly due to the small exponent $(0.15)$ in equation 11 , which indicates a relatively flat slope (weak relation) for the regression line relating $K_{4}$ to $V_{R M}$. In summary, despite vertical variations in coarse bed-material characteristics between the surface and shallow-subsurface bed-material layers, pier-scour depths computed using either set of characteristics were quite similar. The HEC- $18-K_{4} \mathrm{Mu}$ equation was not very sensitive to vertical variations in bedmaterial characteristics within the active layer at coarse-bed sites where pier-scour data were collected for this study.

\section{Combined Effects of Surface and Shallow- Subsurface Bed-Material Characteristics}

In addition to examining the effects that differences in bed-material size and gradation between the surface and shallow-subsurface layers might have on predicted pier-scour depth, the combined effect that the bed-material characteristics of both layers might have on measured pier scour also was examined. The combined effect is of interest because if the critical velocity to initiate scour of bed material at the pier is exceeded, the surface and shallow-subsurface layers could interact and exchange bed material within the active layer until an immobile armor layer re-forms. Lagasse and others (1991) describe the armoring process as the interaction between the surface and shallow-subsurface layers of bed material. For gravel-bed streams where the bed is not composed of immobile armor but is paved so that coarse particles are frequently mobilized, Parker and others (1982, p. 546) indicate that the particle-size distribution of the bedload typically is more similar to the size distribution of the shallow-subsurface layer (subpavement) than to that of the surface layer (pavement). It is therefore conceivable that the bed-material size and gradation characteristics of the two layers in combination can affect pier scour. For example, substantial pier-scour depth might 


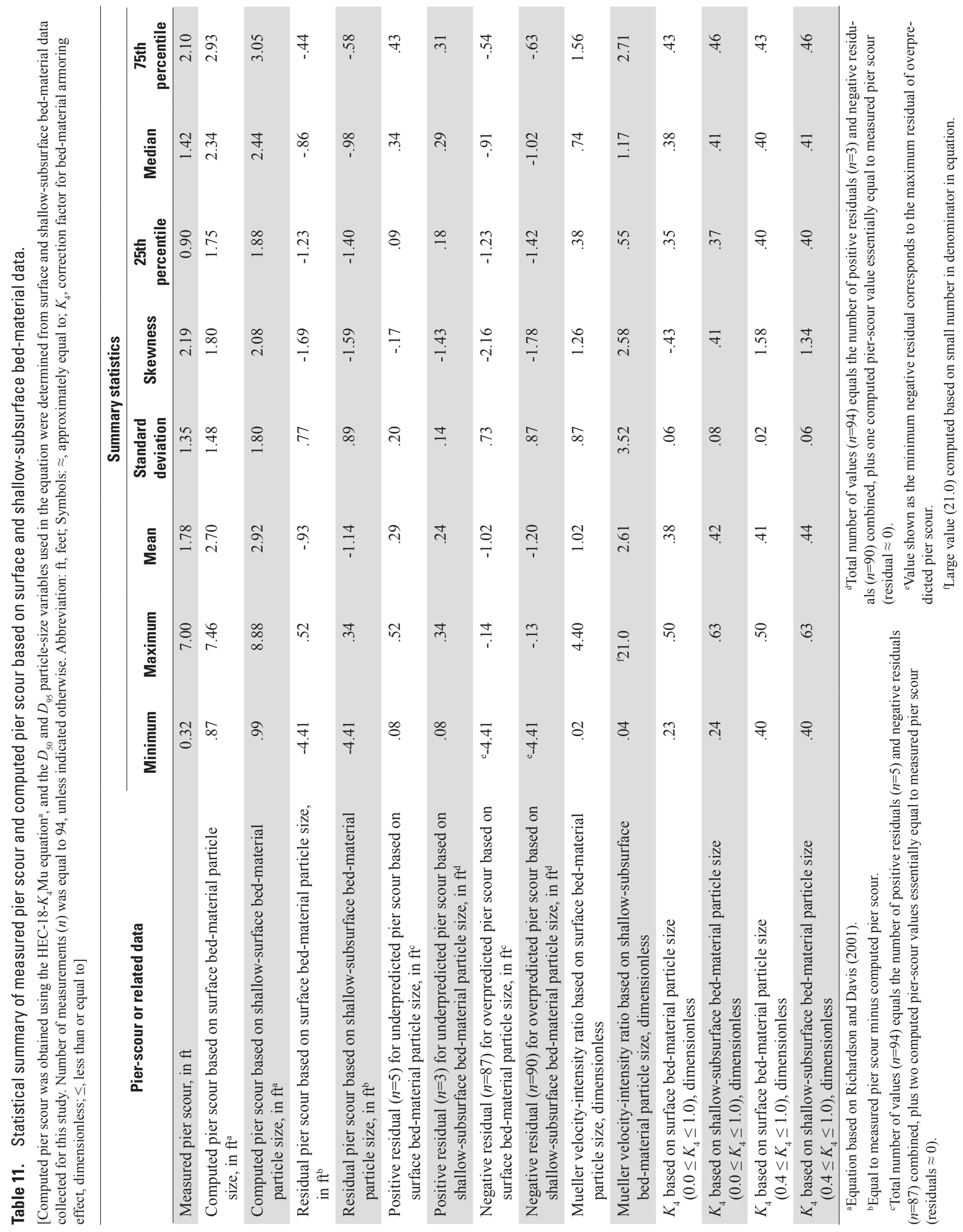



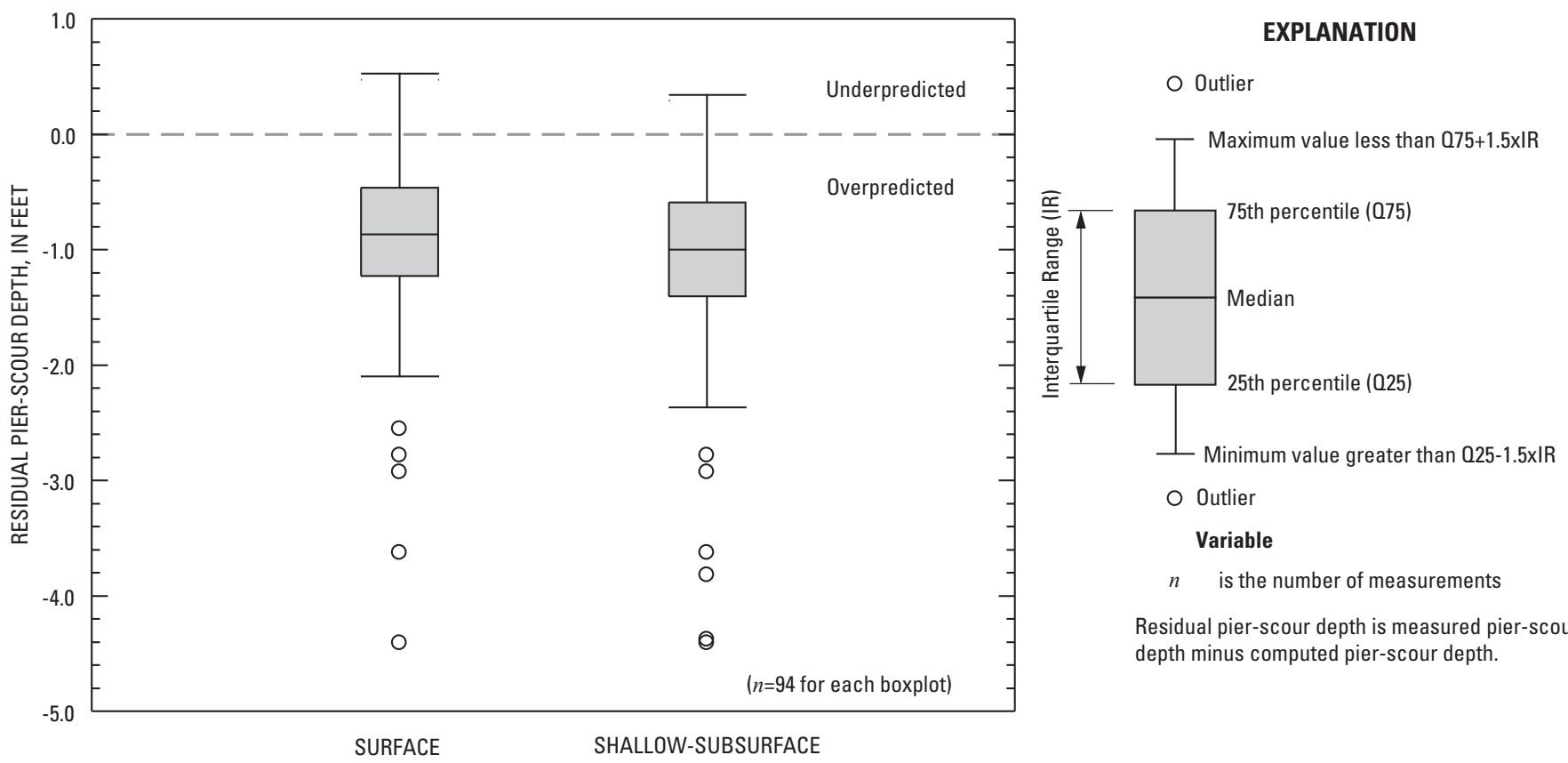

Residual pier-scour depth is measured pier-scour depth minus computed pier-scour depth.

Figure 22. Comparison of residual pier-scour depth based on pier-scour measurements and bed-material data collected for this study with pier-scour depth computed by the HEC-18- $K_{4}$ Mu equation (Richardson and Davis, 2001).

Table 12. Groups of pier-scour measurements based on classification of particle sizes of the surface and shallow-subsurface bed material.

\begin{tabular}{|c|c|c|c|c|}
\hline \multirow[t]{2}{*}{ Combination } & \multicolumn{2}{|c|}{$\begin{array}{l}\text { Bed-material size classification modified } \\
\text { from Lane and others (1947) }\end{array}$} & \multirow{2}{*}{$\begin{array}{c}\text { Number } \\
\text { of } \\
\text { measurements }\end{array}$} & \multirow{2}{*}{$\begin{array}{c}\text { Group } \\
\text { number } \\
\text { (fig. 23) }\end{array}$} \\
\hline & Surface & Shallow-subsurface & & \\
\hline 1 & Small cobble & Small cobble & 17 & 1 \\
\hline 2 & Small cobble & Very coarse gravel & 9 & 2 \\
\hline 3 & Very coarse gravel & Small cobble & 3 & 2 \\
\hline 4 & Very coarse gravel & Very coarse gravel & 23 & 3 \\
\hline 5 & Very coarse gravel & Coarse gravel & 14 & 4 \\
\hline 6 & Coarse gravel & Very coarse gravel & 4 & 4 \\
\hline 7 & Very coarse gravel & Medium gravel & 3 & 4 \\
\hline 8 & Coarse gravel & Coarse gravel & 19 & 5 \\
\hline 9 & Coarse gravel & Medium gravel & 1 & 5 \\
\hline 10 & Medium gravel & Medium gravel & 7 & 5 \\
\hline 11 & Coarse gravel & Very fine gravel & 3 & 5 \\
\hline
\end{tabular}


be expected where a thin layer or pavement of moderately coarse surface bed material like gravel is underlain by much finer subsurface bed material like sand (American Society of Civil Engineers, 1975, reprinted 1977, p. 182). In contrast, less scour might be expected when the bed material of the two layers includes coarse gravel and cobbles and the bed material of one layer has a greater degree of gradation than the other (fig. 4).

The effects that differences in particle size between surface and shallow-subsurface bed-material layers might have on pier scour were investigated first. Examination of the differences in particle sizes between the two layers began by grouping the bed-material particle-size data for each layer into bed-material size classifications (table 3 ) based on the $D_{50}$ particle size. The classifications ranged from small cobble to very fine gravel. The different combinations of surface and shallow-subsurface particle-size classifications for individual scour measurements were examined next. The 103 scour measurements collected for this study exhibited 11 combinations of bed-material size classification involving the surface and shallow-subsurface layers, and the measurements were initially grouped based on these 11 combinations (table 12). Many of the 11 combinations were characteristic of only a small number (four or less) of the 103 pier-scour measurements. Therefore, one or more combinations with only slightly different size characteristics were lumped together into five groups to allow development of envelope curves. The relation between relative velocity, based on the $D_{50}$ of the surface bedmaterial layer, and relative pier scour was examined for pierscour measurements in each group (fig. 23). Based on the five envelope curves drawn to define the upper bounds of the data for each group, relative pier scour generally was less for measurements with coarser bed material like very coarse gravel or cobbles in the two layers (fig. 23). Few other conclusions are apparent from a comparison of the envelope curves.

The relation between relative velocity, based on the average $D_{50}$ for the two bed-material layers, and relative pier scour also was examined and produced similar results. This similarity of results may be because surface and shallow-subsurface bed-material size classifications for both layers were the same or similar for both layers for most measurements (for example, small cobbles in both layers), even though surface bed-
Figure 23. Relation between relative pier scour and relative velocity for different groups of combinations of surface and shallow-subsurface bed-material size classifications for the pier-scour measurements collected for this study.

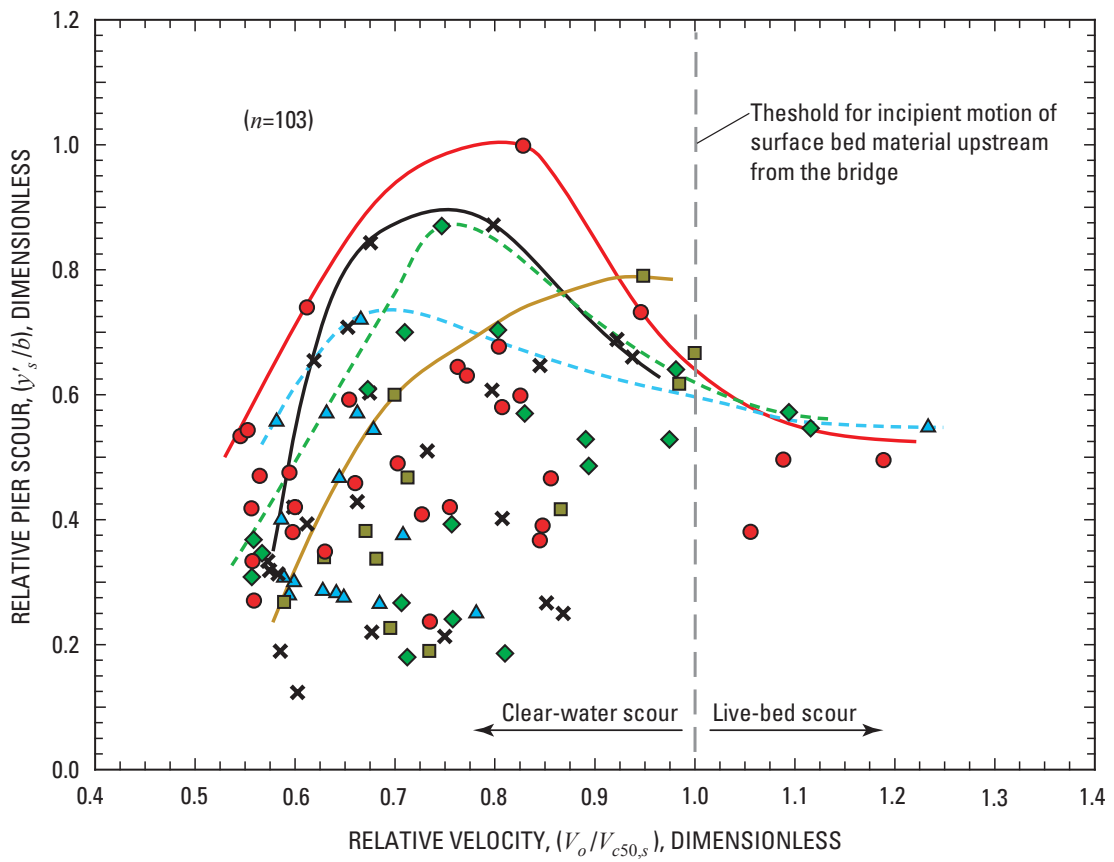

EXPLANATION

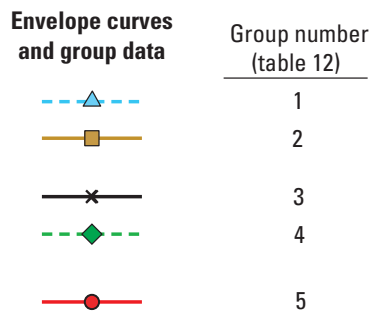

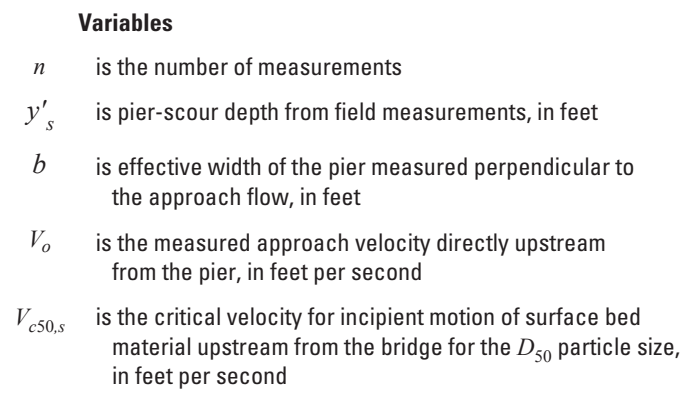


material size typically was larger than the shallow-subsurface bed-material size. There were no sites where the difference in bed-material particle size between the surface or armor layer and shallow subsurface was substantial (for example, small cobbles underlain by very fine gravel or sand); thus, more detailed assessment of such widely contrasting bed-material compositions was not possible.

Differences in gradation of bed material in the surface and shallow-subsurface layers and the relation of these differences to pier scour also were investigated using two approaches. First, the differences in relations between gradation coefficients for each layer and relative pier scour were compared by examining envelope curves for each set of measurements obtained for this study (fig. 24). Maximum relative pier scour corresponded to a gradation coefficient of about 2.3 for the surface bed material and about 4.7 for the shallowsubsurface bed material (fig. 24). This fairly narrow range in gradation coefficients associated with maximum pier scour for the two layers is similar to other studies that showed the narrow range in gradation coefficients associated with maximum pier scour based only on surface bed material (Ettema, 1980; Baker, 1986). A composite envelope curve (fig. 24) was generated as a means to account for the variability in $\sigma_{g}$ as it pertains to the computation of pier-scour depth when results of multiple pebble counts or sieve analyses involving both layers are combined. The composite gradation coefficient $\left(\sigma_{g, c}\right)$ is the geometric mean of the corresponding surface and subsurface $\sigma_{g}$ values.
For the second approach, the variation in gradation over the range of the particle-size distribution curve was defined using the following relation:

$$
R_{g}=\frac{\sigma_{g, s s}}{\sigma_{g, s}}
$$

where

$$
\begin{gathered}
R_{g} \quad \begin{array}{l}
\text { is the relative gradation or the ratio of } \\
\text { shallow-subsurface-to-surface bed-material } \\
\text { gradation coefficient, dimensionless; }
\end{array} \\
\sigma_{g, s s} \quad \begin{array}{l}
\text { is the gradation coefficient of the shallow- } \\
\text { subsurface bed material, dimensionless; } \\
\text { and }
\end{array} \\
\quad \begin{array}{l}
\text { is the gradation coefficient of the surface bed } \\
\text { material, dimensionless. }
\end{array}
\end{gathered}
$$

The relative gradation $\left(R_{g}\right)$ was calculated for each of the 103 pier-scour measurements collected for this study and the measurements were ranked by $R_{g}$ from largest to smallest. Selected percentiles (99th, 75th, 50th, 25th, and 10th) were then determined and the relative pier scour and relative velocity for each measurement in the percentile were plotted to examine the relation between relative pier scour and relative velocity for each percentile. Envelope curves bounding the measurements in each percentile were drawn. Each of the five envelope curves (fig. 25), therefore, bounds a group of pierscour measurements with $R_{g}$ values that equal or exceed a particular value (smallest value) in each percentile. For example, 10 percent of the measurements had $R_{g}$ values that equaled or
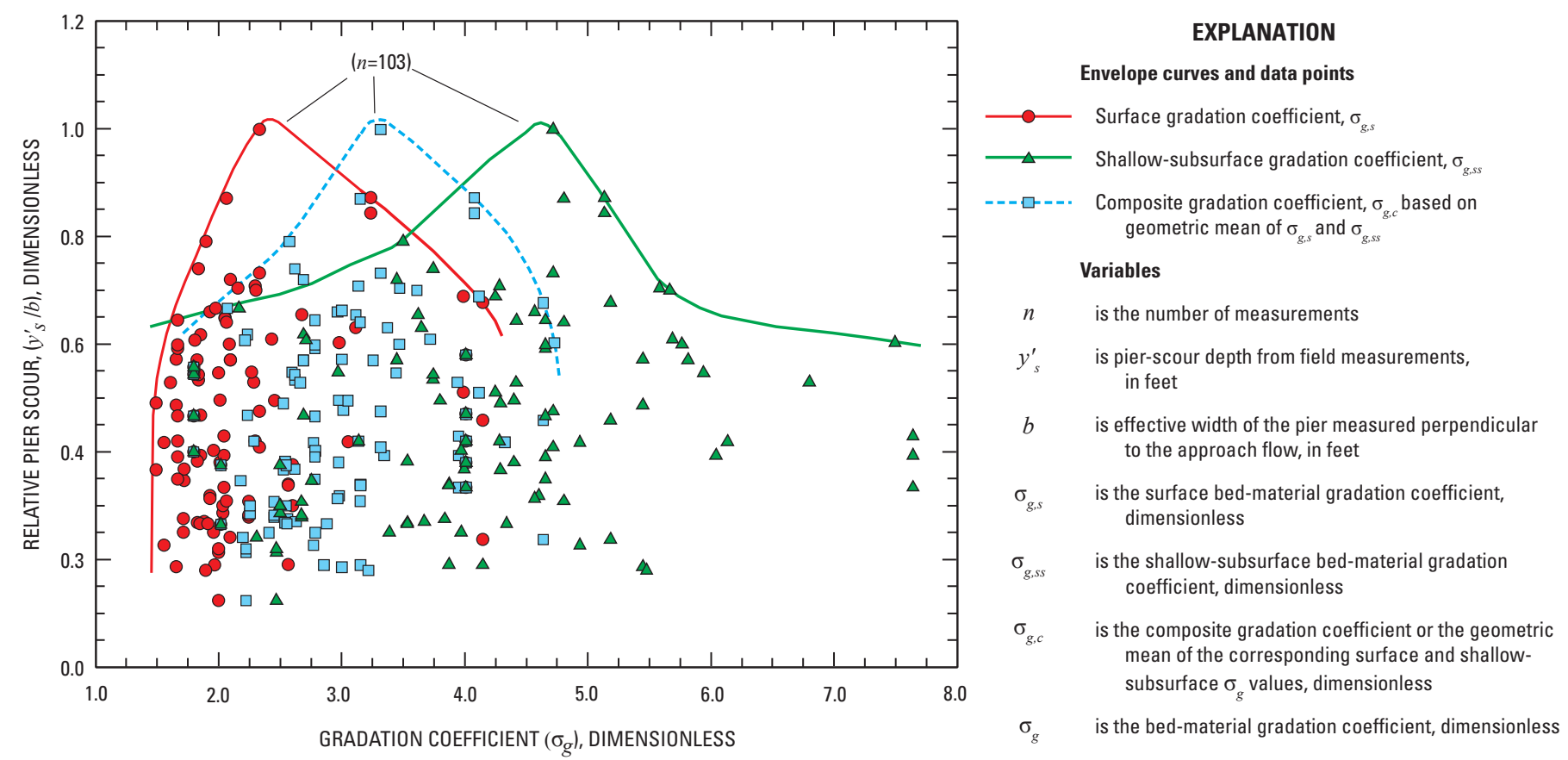

Figure 24. Comparison of relative pier scour to gradation coefficient for surface and shallow-subsurface bed-material data collected for this study. 
exceeded 3.18, so 10 data points $\left(R_{g} \geq 3.18\right.$, fig. 25$)$ were used to define the 10th-percentile envelope curve. Maximum relative scour associated with each envelope curve is concentrated at about the same relative velocity $\left(V_{o} / V_{c 50} \approx 0.75\right.$ to 0.8$)$. The five envelope curves (fig. 25) appear to converge when relative velocities are high enough for live-bed scour conditions to be reached $\left(V_{o} / V_{c 50}>1.00\right)$. Based on these curves, when the difference between the shallow-subsurface and surface bed-material gradation coefficients increases (higher values of $R_{g}$ ), pier scour decreases. Earlier studies reported by Mueller (1996) and Mueller and Wagner (2005) indicated that when the gradation coefficient of the surface bed material increased, pier scour was reduced.

Higher variability in gradation coefficients would seem to indicate the presence of a higher fraction of fine-grained particles with expected deeper scour before armoring. Increased scour associated with finer bed material may, however, be more than offset if sufficiently large particles also are available to hide the smaller particles (Einstein, 1950; Parker and
Klingeman, 1982), limiting overall mobility of bed material and allowing more rapid armoring.

Finally, the combined influence of relative differences in surface and shallow-subsurface bed-material size and gradation on pier scour was investigated by defining a bed-material variability index $\left(I_{v}\right)$ :

$$
I_{v}=\frac{D_{50, s}}{D_{50, s s}}+\frac{D_{95, s}}{D_{95, s s}}+\frac{\sigma_{g, s s}}{\sigma_{g, s}},
$$

Substitution based on equations 23 and 24 yields:

$$
I_{v}=R_{50}+R_{95}+R_{g}
$$

where all terms are as previously defined. The three variables on the right hand side of equation 26 were derived from variables $\left(D_{50}, D_{95}\right.$, and $\left.\sigma_{g}\right)$ shown to be related to pier scour in coarse-bed streams as noted in this section and other studies cited in the section "Development of Pier-Scour Equations for
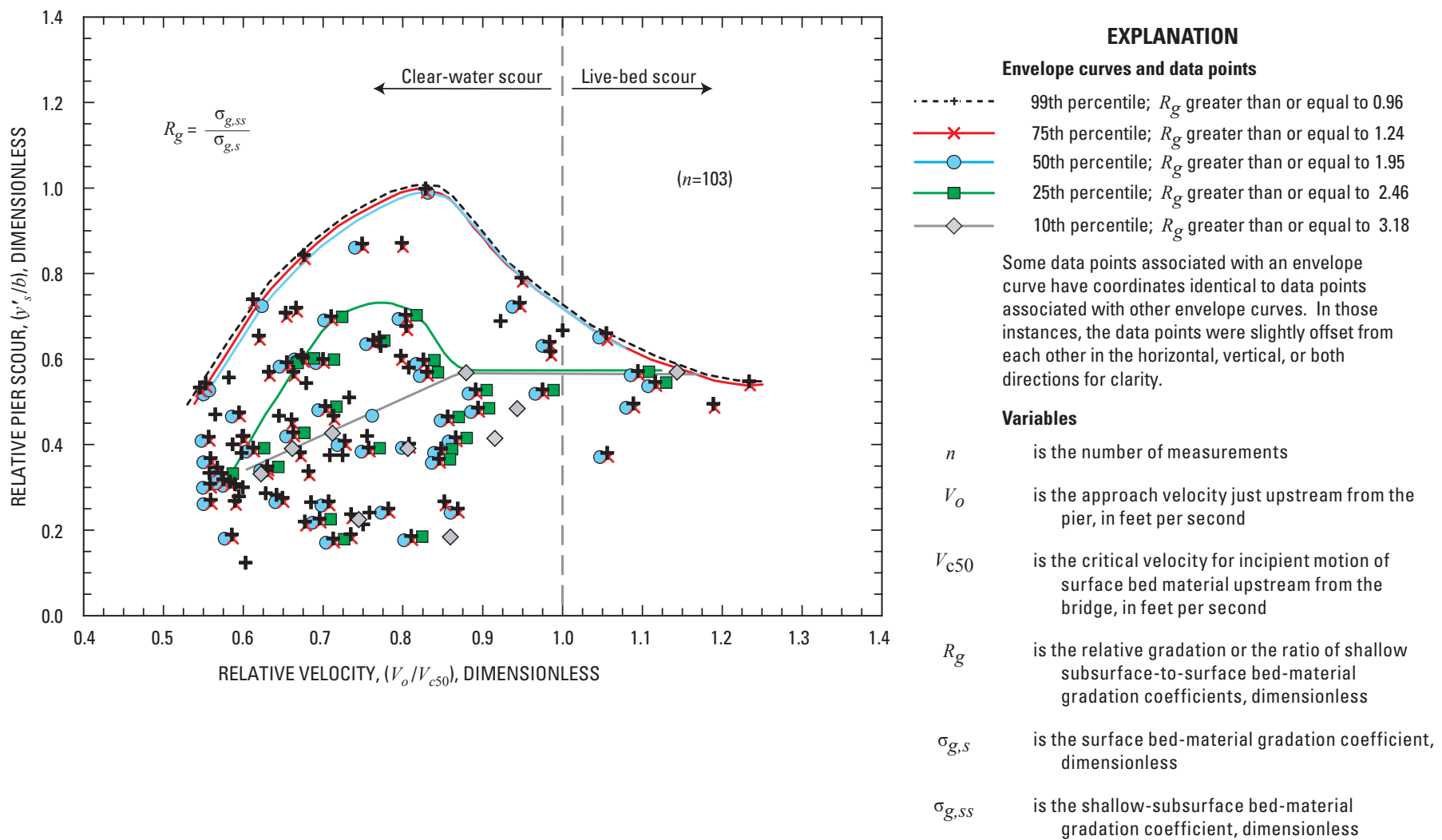

Figure 25. Relation between relative pier scour and relative velocity based on surface and shallow-subsurface bed-material gradation differences for pier-scour measurements collected for this study. 
Coarse-Bed Streams." These variables have about the same magnitude and, therefore, have a similar influence on the values of $I_{v}$. Based on research cited in the section "Development of Pier-Scour Equations in Coarse-Bed Streams," that showed pier scour to be less for coarse-size bed material with higher gradation coefficients, perfect homogeneity (where $R_{50}, R_{95}$, and $R_{g}$ each equal 1.00 in equation 26) between surface and shallow-subsurface bed-material size and gradation $\left(I_{v}=3.00\right)$ might be expected to result in greater relative pier scour than a condition where, for example, the relative homogeneity of size and gradation varied by a factor of two for each ratio $\left(I_{v}=6.00\right)$.

The bed-material variability index $\left(I_{v}\right)$ was calculated for each of the 103 measurements collected for this study and the measurements were ranked by $I_{v}$ from largest to smallest. Selected percentiles (99th, 75th, 50th, 25th, and 10th) were determined and the relative pier scour and relative velocity for each measurement in the percentile were plotted to examine the relation between relative pier scour and relative velocity for each percentile. Envelope curves bounding the measurements in each percentile were drawn. Each of the five envelope curves (fig. 26), therefore, bounds a group of pier-scour measurements with $I_{v}$ values that equal or exceed a particular value (smallest value) in each percentile group. For example, 10 percent of the measurements had $I_{v}$ values that equaled or exceeded 6.48 , so 10 data points $\left(I_{v} \geq 6.48\right.$, fig. 26$)$ were used to define the 10th-percentile envelope curve. Maximum relative scour associated with each envelope curve is concentrated at about the same relative velocity $\left(V_{o} / V_{c 50} \approx 0.80\right)$. The five envelope curves (fig. 26) appear to converge when relative velocities are high enough for live-bed scour conditions to be reached $\left(V_{o} / V_{c 50}>1.00\right)$. Based on these curves, as differences in particle size and gradation between the surface and shallowsubsurface bed-material layers increase (higher values of $I_{v}$ ), pier scour decreases. These curves also exhibit the potential to refine estimates of maximum relative pier scour using the bedmaterial variability index or a similar variable.

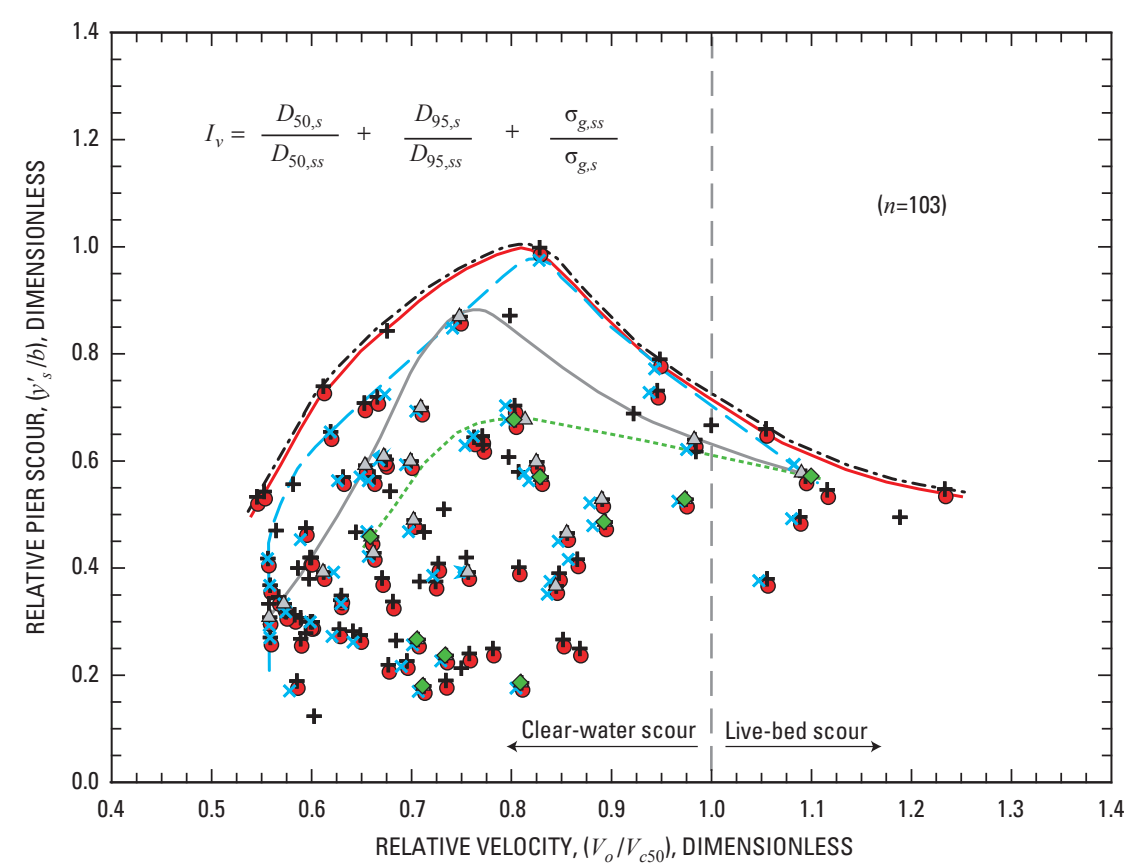

Figure 26. Relation between relative pier scour and relative velocity based on surface and shallow-subsurface bed-material size and gradation differences for pier-scour measurements collected for this study.

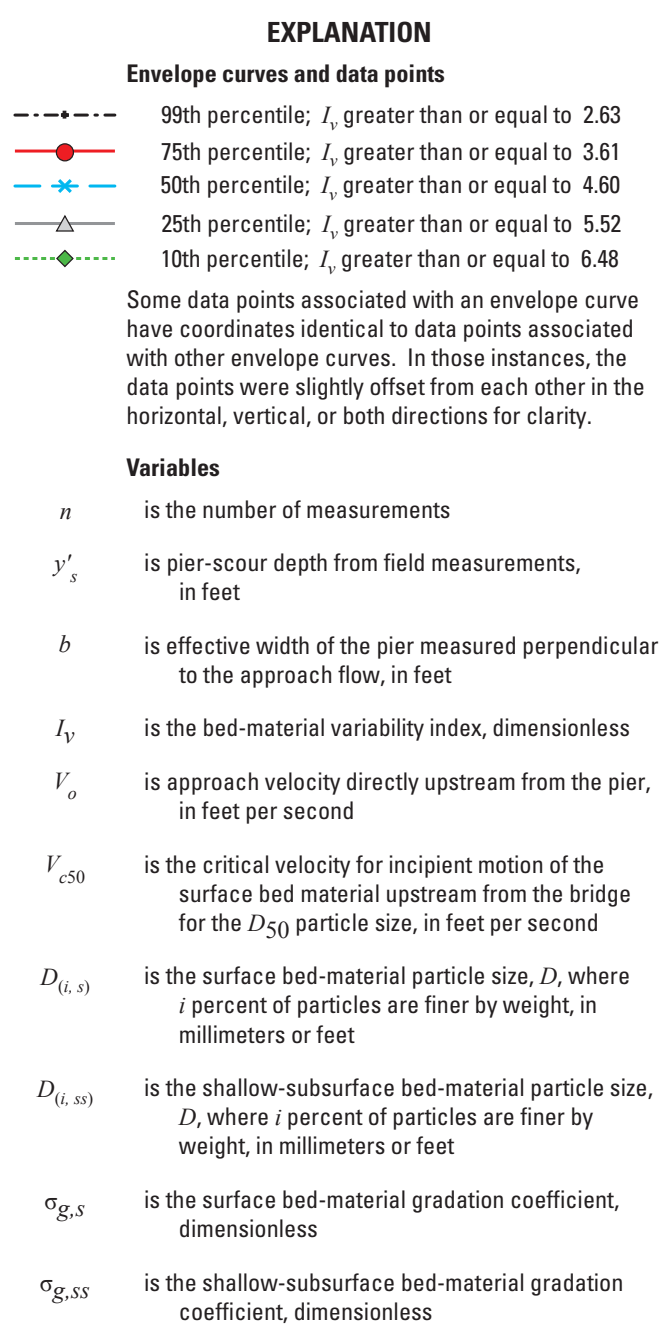

EXPLANATION

nvelope curves and data points

99th percentile; $I_{v}$ greater than or equal to 2.63 75th percentile; $I_{v}$ greater than or equal to 3.61 50th percentile; $I_{v}$ greater than or equal to 4.60

25th percentile; $I_{v}$ greater than or equal to 5.52 10th percentile; $I_{v}$ greater than or equal to 6.48

ted with an envelope curve with other envelope curves. In those instances, the data points were slightly offset from each other in the horizontal, vertical, or both directions for clarity.

Variables

pier-scour depth from field measurements, to the approach flow, in feet in feet per second

e critical velocity for incipient motion of the surface bed material upstream from the bridg the surface bed-material particle size, $D$, where $i$ percent of particles are finer by weight, in eters or feet $D$, where $i$ percent of particles are finer by coefficient, dimensionless 


\section{Limitations of the Study}

Field measurement of scour at bridge piers requires the use of specialized equipment and methods to obtain accurate data. The collection of real-time scour data also requires that measurements be made during high-flow conditions. Although methods for conducting scour-depth measurements generally are described in various USGS publications, innovation, physical effort, and judgment are required in obtaining usable pier-scour data under difficult field conditions. A series of measurement and interpretive steps are needed to compute the measured pier-scour depth. Except for three sites where continuous scour measurements were made over the entire runoff period by using fixed instrumentation, most measurements for this study were conducted over a few hours on a single day. Continuous transducer soundings made at one site indicated that maximum pier scour was attained several times during a 2-month period in 2006 for flows that ranged from less than to about bankfull discharge, which provide some insight on the site-specific effects of high-flow duration on pier scour. High-flow duration effects on pier scour, however, were not addressed beyond this one example.

Runoff conditions during the study mostly were limited to bankfull discharge approximating the 1.5- to 2-year recurrence-interval flood. Lack of higher flows having greater velocity intensities may indicate that scour depths were limited by hydrologic conditions. Still, scour measurements made mostly under clear-water conditions associated with maximum scour involved relatively high velocity intensities. In fact, measured velocities at one-half of study sites were at least 70 percent of the critical velocity for incipient motion of the bed material upstream from the bridge, which might indicate that scour was measured near the threshold between clearwater and live-bed scour conditions. Laboratory research using fine-grained material and steady-flow conditions indicates that this threshold is where maximum pier scour likely occurs. Furthermore, historical pier-scour data from Montana with peak streamflows of greater recurrence interval (up to about 100 years) plotted below envelope curves (figs. 10, 11, and 14) that bound the data collected for this study and BSDMS data. Pier-scour depths measured in this study also may have been limited by streambed armoring and unsteady flow conditions.

It is critical for bed-material samples to be representative of the actual streambed materials if these data are to be related to maximum pier-scour depth and used to improve equations to predict pier scour. A single bed-material sample considered to be representative of overall conditions was obtained for most sites. At 10 percent of the sites, multiple sets of pebble counts ( 3 to 4 , table 4 ) were obtained. Results indicated that the standard deviation of the particle-size was small in most instances when compared to the corresponding mean particle size at each percentile analyzed.

Corresponding data for surface and shallow-subsurface bed-material characteristics obtained at all sites provided an indication of the vertical variability of the particle size. Relations between relative pier scour and relative velocity involving surface and shallow-subsurface bed-material characteristics were limited to the data obtained in this study; no comparable data were found in the BSDMS database. Thus, surface-to-shallow-subsurface relations need to be considered as preliminary. Additional data from bridge sites with a wider range in bed-material size and gradation are needed to verify the relations presented and perhaps use this information to improve scour-prediction equations for use at sites with similar bed-material characteristics. An independent dataset also would be needed to verify the validity of surface-to-shallowsubsurface relations proposed in this study.

Although differences between surface and shallowsubsurface bed-material size and gradation resulted in no substantial difference in computed scour depths, the spatial variability in bed-material composition needs to be considered in assessing the site-specific effect that bed-material size and gradation differences have on predicted pier scour. Furthermore, there may be combinations not investigated in this study where the bed-material differences in the two layers are more substantial and lead to greater differences in predicted scour depth. Future investigations of relations between bed-material characteristics and pier scour will require detailed description of sampling location (areally, vertically, or both) for the bed-material data collected. Some difficulty is likely to be encountered in collecting subsurface bed-material samples at sites where the streambed is always under a substantial depth of water or velocities are excessive, which is common in some regions of the United States. Conclusions presented for this study are generally limited to the range of hydraulic conditions and bed-material characteristics demonstrated in the data collected for this study and BSDMS data.

\section{Summary and Conclusions}

Determination of pier-scour potential is an important consideration in the hydraulic analysis and design of highway bridges that cross streams, rivers, and other waterways in the United States. A primary goal of ongoing research in the field of bridge scour is to improve equations currently used (2011) so that scour depth is neither underpredicted nor excessively overpredicted. Research efforts, therefore, continue to evaluate and improve the accuracy of pier-scour equations. Since the early 1990s, research has expanded to include field measurements of pier scour during high-flow conditions. Based on these measurements, scour depth for piers in noncohesive, nonuniform streambeds with a mixture of sand, gravel, cobbles, and boulders (coarse-bed streams) generally is less than the scour depth in finer-grained (mostly sand) streambeds under similar hydraulic conditions. The difference in scour depth is attributed to formation of an armor layer. This finding, supported by field measurements collected by the U.S. Geological Survey (USGS), has led to modifications in the scour equations recommended by the Federal Highway Administration (FHWA). Pier-scour data collected by the USGS were 
used to develop a bed-material correction factor called $K_{4}$. Collection of additional coarse-bed pier-scour data was recommended to further validate the method for computing $K_{4}$ and to provide additional data for continued evaluation of pierscour equations. The Montana Department of Transportation (MDT) was interested in pier-scour prediction in coarse-bed streams because coarse-bed streams are common in Montana. Furthermore, the USGS has collected bridge-scour data and conducted bridge-scour investigations since the early 1990s in cooperation with MDT. Consequently, the USGS and MDT began a cooperative study in 2001 to investigate pier scour in coarse-bed streams in Montana.

This report presents the results of a study of pier scour in coarse-bed streams during 2001-07 in the mountain and foothill regions of three major river basins in Montana: the Missouri, Yellowstone, and Clark Fork of the Columbia. Drainage areas for the streams at bridge sites where measurements were collected ranged from about $3 \mathrm{mi}^{2}$ to almost $20,000 \mathrm{mi}^{2}$. The report also describes how coarse-bed pier-scour measurements were collected, shows the extent that the coarse portion of the national pier-scour database was expanded, discusses how these new data were used to evaluate the relative accuracy of various equations for predicting scour in coarse-bed streams, and demonstrates how differences in size and gradation between surface bed material and bed material underlying the surface layer (shallow-subsurface bed material) might relate to pier scour.

The equation widely adopted for conducting pier-scour analysis and design in the United States was developed at Colorado State University in the mid-1970s. A modified version of the equation was later published by FHWA in Hydraulic Engineering Circular No. 18 (HEC-18) and is called the HEC-18 equation. The current (2011) version of the HEC-18 pier-scour equation recommended by the FHWA includes the computation of $K_{4}$, and is referred to in this report as the HEC-18- $K_{4} \mathrm{Mu}$ equation. Pier-scour research has continued and new equations have been proposed that include the $K_{4}$ correction factor.

Methods based on limited-detail field procedures described in literature and equipment ranging from simple scour rods to complex hydroacoustic instrumentation were used to obtain pier-scour measurements. Data collected in the field for this study included information needed to measure pier scour along with bed material and ancillary data needed to compute scour using equations. Bed-material sizes used in scour-prediction equations were determined from the surface bed material that generally reflected the armor layer. The potential interaction between the surface and shallowsubsurface bed-material layers with respect to pier scour and armoring also was of interest for this study. Therefore, shallow-subsurface bed material also was sampled and data were compared to surface bed-material data for each site. Surface and shallow-subsurface bed-material measurements were obtained by pebble counts and sieve analyses. Bed-material data were used to construct particle-size distribution curves, which were used to conduct various coarse-bed pier-scour analyses. Surface and shallow-subsurface bed material sampled for this study was used to evaluate the sensitivity of computed scour to size and gradation differences between the two layers, and these data for each layer were used to assess the effects of bed-material characteristics on pier scour.

Pier-scour measurements were made during 2001 through 2007 at 59 bridge sites on coarse-bed streams. Of those measurements, 103 satisfied criteria requiring that the measured approach velocity $\left(V_{o}\right)$ exceed the critical velocity $\left(V_{c 50}^{\prime}\right)$ to initiate scour of bed material at the piers and were analyzed for this study. Incipient motion computations based on the $D_{50}$ particle size indicated that 96 out of 103 pier-scour measurements were made under clear-water scour conditions, when the streambed upstream from the bridge is stable and there is no substantial incoming sediment supply to the bridge opening. Of the measurements made, 50 percent had an approach velocity that equaled or exceeded 70 percent of the critical velocity $\left(V_{c 50}\right)$ for incipient motion of bed material upstream from the bridge. This might indicate that scour was measured near the threshold between clear-water and live-bed scour $\left(V_{o} / V_{\mathrm{c} 50}=1.00\right)$ where maximum pier scour was shown in laboratory studies. Despite reasonably high approach velocities, measured pier scour was less than a couple of feet in depth for 70 percent of the measurements made at the coarsebed sites. Particle size of sampled surface bed material was predominantly very coarse gravel based on the $D_{50}$ particle size. Surface bed material at one-half of the sites lacked substantial gradation, as indicated by gradation coefficients $\left(\sigma_{g}\right)$ less than about 2.0. About 60 percent of the sites were located on high-gradient streams based on water-surface slopes that exceeded 0.002 . The approach depth of flow $\left(y_{o}\right)$ in relation to the effective pier width $(b)$ was not substantial, with flow depth typically less than twice the effective pier width. The effects of high-flow duration on pier scour were not investigated because most scour data for a site were collected in a single day. Continuous scour measurements made at three sites using fixed acoustic transducers, however, indicated that scour typically increased as streamflow increased.

Pier-scour data collected for this study were compared to pier-scour data from other USGS studies that were used to develop pier-scour equations for coarse-bed streams. Historical data were retrieved from the Bridge Scour Data Management System (BSDMS). The 508 measurements in the BSDMS database collected between 1965 and 1998 were initially screened down to 272 measurements (BSDMS All) with bed material that was noncohesive and composed of sand and coarser particles, and then to 90 measurements (BSDMS Coarse). The BSDMS Coarse dataset is comparable with data collected for this study based on FHWA criteria for $D_{50}$ and $D_{95}$ particle size that defines coarse bed material. The median $D_{50}$ and $D_{95}$ bed-material size for data collected for this study are about 1.8 and 1.6 times (respectively) the size of $D_{50}$ and $D_{95}$ in the BSDMS Coarse dataset. The maximum value of relative pier scour $\left(y_{s}^{\prime} / b\right)$ in the study was 1.00 , and the maximum values observed in the two BSDMS datasets (All, Coarse) were 2.09 and 1.25, respectively. Data from this study 
also were compared to historical pier-scour measurements made in Montana by USGS during large floods. Nine pierscour measurements made at three sites were for peak streamflows approximating the 100-, 10-, and 5-year recurrence intervals, which are much greater than any recurrence intervals associated with measurements made for this study and provide an independent check on the envelope curves bounding the upper end of both the data collected for this study and BSDMS data combined.

Pier-scour depth was computed for the measurements collected for this study using the HEC-18 equation with no $K_{4}$ correction factor and five pier-scour equations that use $K_{4}$ for the armoring effect of coarse bed material. Computed scour depths were compared to measured scour depths using scatter plots and boxplots of residuals to evaluate the reliability of the equations to predict pier scour. The HEC-18- $K_{4} \mathrm{Mu}$ equation was the best equation for predicting pier-scour depth in coarsebed streams because the equation generally predicted pier scour in closer agreement to measured scour than the other equations used for computing pier-scour depth. Furthermore, the magnitude of the residuals of underpredicted and overpredicted scour depth was the lowest using the HEC- $18-K_{4} \mathrm{Mu}$ equation.

The effect of bed-material size and gradation on scour depth was investigated using data collected for this study, the BSDMS All dataset, and the BSDMS Coarse dataset to confirm and extend the findings of previous studies. Previous research showed that the equation for computing $K_{4}$ can produce anomalous results (negative velocity ratio) for rare combinations of $D_{50}$ and $D_{95}$. None of the surface bed-material particle-size data collected for this study produced anomalous results in computing $K_{4}$. Regression analysis conducted in this study showed that the $D_{50}$ and $D_{95}$ particle sizes have a positive relation with each other that is statistically significant $\left(r^{2}=0.73\right.$ and $\left.p<0.001\right)$. In other words, for the data collected for this study, sites that have a larger $D_{50}$ particle size also tend to have a larger $D_{95}$ particle size. This observation is similar to the observation of previous research about the bedmaterial data originally used to develop the equation for the $K_{4}$ correction factor.

The relation between relative pier scour $\left(y_{s}^{\prime} / b\right)$ and relative velocity $\left(V_{o} / V_{c 50}\right)$ defined by an envelope curve for the data collected for this study and the BSDMS Coarse dataset were compared to relations observed in laboratory data. The envelope curve for data used for this study displays an earlier peak, with a decrease in relative pier scour followed by an asymptotic rise; the first peak in the curve occurs at a lower relative velocity than the clear-water and live-bed threshold $\left(V_{o} / V_{c 50}=1.00\right)$. The magnitude of relative pier scour (maximum of 1.25) is much less than the published maximum value of 2.4 obtained from laboratory data. Furthermore, equilibrium live-bed scour is about 18 percent shallower than the maximum pier scour under clear-water conditions, a larger reduction than the 10 percent indicated in literature. Armoring associated with nonuniform coarse-bed material and unsteadyflow conditions in the field probably accounts for differences between envelope curves developed for this study and those from previous studies conducted in the laboratory using finegrained material and steady-flow conditions.

Previous studies showed that surface bed-material gradation affected pier-scour depth, therefore, the relation between gradation coefficient $\left(\sigma_{g}\right)$ and relative pier scour was investigated using the pier-scour measurements collected for this study. Gradation coefficients associated with surface bed material collected for this study ranged from 1.48 to 4.14, with a median of 2.01. Bed-material data collected for this study had sufficient gradation so that streambed armoring was possible according to criteria developed in previous research. As shown in previous research, for data collected for this study and the BSDMS Coarse dataset, maximum relative pier scour is greater when $\sigma_{g}$ is less than or equal to 2.5. Pier-scour measurements collected for this study and BSDMS confirm a general lack of data for coarse-bed sites with $\sigma_{g}$ greater than about 2.5. The narrow range in gradation coefficients displayed by all available data and the nonuniform conditions present in the field continue to complicate efforts to isolate the effects of gradation on pier scour.

Since the mid-1960s, pier-scour research has focused primarily on surface bed material effects on pier scour. Surface and shallow-subsurface bed material were collected and analyzed for both layers during this study. Median $D_{50}$ particle sizes for 103 surface and shallow-subsurface bedmaterial samples were about $49 \mathrm{~mm}$ and $32 \mathrm{~mm}$, respectively, and median $D_{95}$ particle sizes for 103 surface and shallowsubsurface bed material samples were $122 \mathrm{~mm}$ and $86 \mathrm{~mm}$, respectively. The median gradation coefficients for surface and shallow-subsurface bed material associated with measurements made for this study were 2.01 and 4.14 , respectively. The combined effect of the larger surface bed-material size relative to shallow-subsurface bed-material size and the wider range of gradation coefficients in shallow-subsurface bed material is typical for the pier-scour measurements made for this study and may contribute to reduced pier scour in these coarse-bed streams. A significant relation was indicated between surface and shallow-subsurface bed-material size, for the $D_{50}$ and $D_{95}$ particle sizes (for $D_{50}, r^{2}=0.690$ and $p<0.001$; for $D_{95}, r^{2}=0.647$ and $p<0.001$ ). In other words, as the particles in the surface bed material increase in size, the particles in the shallow-subsurface bed material also tend to increase in size. Based on observed field conditions, and the relative coarseness of the bed-material particle sizes for the two layers, particle-size data for the shallow-subsurface bed material underlying the armor layer also were used to compute pier scour by the HEC-18- $K_{4}$ Mu equation. Scour depths computed based on shallow-subsurface particle sizes were then compared to both measured scour depths and scour depths computed based on the surface bed-material particle-size data. Differences in $D_{50}$ and $D_{95}$ particle size between the surface and shallow-subsurface bed material did not cause substantial differences in computed scour. The frequency and magnitude of the residual pier-scour depth associated with underpredicted and overpredicted scour was about the same regardless of 
which particle-size data were used with the HEC- $18-K_{4} \mathrm{Mu}$ equation.

In addition to examining the effects that differences in bed-material size and gradation between the surface and shallow-subsurface layers might have on predicted pier-scour depth, the combined effect that the bed-material characteristics of both layers might have on measured pier scour also was examined. Examination of the differences in particle sizes between the two layers began by grouping the bed-material particle-size data for each layer into classifications that ranged from small cobble to very fine gravel. Different combinations of surface and shallow-subsurface bed-material size classifications were used to group the pier-scour measurements, and the relation between relative pier scour and relative velocity was examined for each of these groups of measurements. Based on the five envelope curves drawn to define the upper bounds of the data for each group, relative pier scour was generally less for pier-scour measurements with coarser bed material like very coarse gravel or cobbles in the two layers. There were no sites where the difference in bed-material particle size between the surface or armor layer and shallow-subsurface layer was substantial (for example, small cobbles underlain by very fine gravel or sand); thus, more detailed assessment of such widely contrasting bed-material compositions was not possible.

Differences in gradation of bed material in the surface and shallow-subsurface layers and the relation of these differences to pier scour also were investigated using two approaches. First, the differences in relations between gradation coefficients for each layer and relative pier scour were compared by examining envelope curves for each set of measurements obtained for this study. Maximum relative pier scour corresponded to a gradation coefficient of about 2.3 for the surface bed material and about 4.7 for the shallowsubsurface bed material. A composite curve was proposed that incorporates the separate relation of both layers. For the second approach, the variation in gradation over the range of the particle-size distribution curve was defined using ratios of shallow-subsurface-to-surface gradation coefficient (relative gradation, $R_{g}$ ) for each of 103 pier-scour measurements collected for this study. The measurements were ranked by $R_{g}$ from largest to smallest, selected percentiles were determined, and the relative pier scour and relative velocity for each measurement in the percentile were plotted to examine the relation between relative pier scour and relative velocity for each percentile. Envelope curves bounding the measurements in each percentile were drawn. Maximum relative scour associated with each envelope curve was concentrated at about the same relative velocity. Based on these curves, when the difference between the shallow-subsurface and surface bedmaterial gradation coefficients increases (higher values of $R_{g}$ ), pier scour decreases.

Finally, the combined influence of relative differences in surface and shallow-subsurface bed-material size and gradation on pier scour was investigated by defining a bedmaterial variability index $\left(I_{v}\right)$ based on ratios of particle sizes and gradation coefficients between layers. The bed-material variability index was calculated for each of the 103 measurements collected for this study and the measurements were ranked by $I_{v}$ from largest to smallest. Selected percentiles were determined and the relative pier scour and relative velocity for each measurement in the percentile were plotted to examine the relation between relative pier scour and relative velocity for each percentile. Envelope curves bounding the measurements in each percentile were drawn. Maximum relative scour associated with each envelope curve was concentrated at about the same relative velocity. Based on these curves, as differences in particle size and gradation between the surface and shallow-subsurface bed-material layers increase (higher values of $I_{v}$ ), pier scour decreases.

Field measurement of scour at bridge piers requires the use of specialized equipment and methods to obtain accurate data under difficult field conditions, and interpretive steps are involved to compute the measured pier-scour depth. Runoff conditions during the study mostly were limited to bankfull discharge approximating the 1.5- to 2-year recurrence-interval flood, which have a 67- and 50-percent chance, respectively, of happening in any year. Lack of higher flows having greater velocity intensities may indicate that scour depths were limited by hydrologic conditions. Pier-scour depths measured in this study also may have been limited by streambed armoring and unsteady flow conditions. A single bed-material sample considered to be representative of overall conditions was obtained for most sites. Relations between relative pier scour and relative velocity involving surface and shallow-subsurface bed-material characteristics were limited to the data obtained in this study; no comparable data were found in the BSDMS database. Thus, surface-to-shallow-subsurface relations need to be considered as preliminary. Conclusions presented for this study are generally limited to the range of hydraulic conditions and bed-material characteristics demonstrated in the data collected for this study and the BSDMS data.

\section{References Cited}

Abdou, M.I., 1993, Effect of sediment gradation and coarse material fraction on clear-water scour around bridge piers: Fort Collins, Colorado State University, Ph.D. dissertation, $181 \mathrm{p}$.

American Society of Civil Engineers, 1975, reprinted 1977, Task Committee for the Preparation of the Manual of Sedimentation, in Vanoni, V.A., ed., Sedimentation engineering: New York, The Society, 745 p.

Andrews, E.D., 1983, Entrainment of gravel from naturally sorted riverbed material: Geological Society of America Bulletin, v. 94, no. 10, p. 1,225-1,231.

Baker, R.E., 1986, Local scour at bridge piers in non-uniform sediment: Auckland, New Zealand, University of Auckland, School of Engineering, Project Report No. 402, 91 p. 
Bunte, Kristen, and Abt, S.R., 2001, Sampling surface and subsurface particle-size distributions in wadable graveland cobble-bed streams for analysis in sediment transport, hydraulics, and streambed monitoring: U.S. Department of Agriculture, Forest Service, Rocky Mountain Research Station, General Technical Report, RMRS-GTR-74, 428 p.

Chase, K.J., and Holnbeck, S.R., 2004, Evaluation of pierscour equations for coarse-bed streams: U.S. Geological Survey Scientific Investigations Report 2004-5111, 18 p.

Chiew, Y.M., 1984, Local scour at bridge piers: Auckland, New Zealand, University of Auckland, School of Engineering, Project Report No. 355, 200 p.

Davis, B.E., 2005, A guide to the proper selection and use of federally approved sediment and water-quality samplers: U.S. Geological Survey Open File Report 2005-1087, 20 p.

DeVries, Paul, 2002, Bedload layer thickness and disturbance depth in gravel bed streams: American Society of Civil Engineers, Journal of Hydraulic Engineering, v. 128, no. 11, p. 983-991.

Einstein, H.A., 1950, The bedload function for sediment transportation in open channel flows: U.S. Department of Agriculture, Soil Conservation Service, Technical Bulletin $1026,71 \mathrm{p}$.

Ettema, Robert, 1976, Influence of bed gradation on local scour: Auckland, New Zealand, University of Auckland, School of Engineering, Project Report No. 124, 200 p.

Ettema, Robert, 1980, Scour at bridge piers: Auckland, New Zealand, University of Auckland, School of Engineering, Project Report No. 236, 527 p.

Gao, D.G., Posada, L.G., and Nordin, C.F., 1993, Pier scour equations used in the People's Republic of China-Review and summary: U.S. Department of Transportation, Federal Highway Administration Publication FHWA-SA-93-076, $66 \mathrm{p}$.

Gessler, Johannes, 1971, Beginning and ceasing of sediment motion, in Shen, H.W., ed., River Mechanics, v. 1, chap. 7: Fort Collins, Colo., Water Resources Publications, p. $7-1-7-22$.

Ghilani, C.D. and Wolf, P.R., 2008, Elementary surveying: An introduction to geomatics (12th ed.): Upper Saddle River, N.J., Pearson Prentice Hall, 931 p.

Guy, H.P., 1969, Laboratory theory and methods for sediment analysis: U.S. Geological Survey Techniques of WaterResources Investigations, book 5, chap. C1, 58 p.

Helsel, D.R., and Hirsch, R.M., 2002, Statistical methods in water resources: U.S. Geological Survey Techniques of Water-Resources Investigations, book 4, chap. A3, 524 p.
Holnbeck, S.R., 2005, Sediment-transport investigations of the upper Yellowstone River, Montana, 1999 through 2001-Data collection, analysis, and simulation of sediment transport: U.S. Geological Survey Scientific Investigations Report 2005-5234, 69 p.

Jarrett, R.D., 1984, Hydraulics of high-gradient streams: American Society of Civil Engineers, Journal of Hydraulic Engineering, v. 110, no. 11, p. 1,519-1,539.

Jarrett, R.D., and Boyle, J.M., 1986, Pilot study for collection of bridge scour data: U.S. Geological Survey WaterResources Investigations Report 86-4030, 46 p.

Lagasse, P.F., Schall, J.D., Johnson, F., Richardson, E.V., Richardson, J.R., and Chang, F., 1991, Stream stability at highway structures: U.S. Department of Transportation Publication FHWA-IP-90-014, Hydraulic Engineering Circular 20, $195 \mathrm{p}$.

Landers, M.N., and Mueller, D.S., 1996, Channel scour at bridges in the United States: U.S. Department of Transportation Publication No. FHWA-RD-95-184, 128 p.

Landers, M.N., Mueller, D.S., and Martin, G.R., 1996, Bridge scour data management system user's manual: U.S. Geological Survey Open-File Report 95-754, 72 p.

Lane, E.W., and others, 1947, Report of the subcommittee on sediment terminology: American Geophysical Union Transactions, v. 28 , no. 6 , p. $936-938$.

Lawlor, S.M., 2004, Determination of channel-morphology characteristics, bankfull discharge, and various design-peak discharges in western Montana: U.S. Geological Survey Scientific Investigations Report 2004-5263, 19 p.

Lisle, T.E., and Madej, M.A., 1992, Spatial variation in armouring in a channel with high sediment supply, in Billi, P., and others, eds., Dynamics of gravel-bed rivers: New York, John Wiley and Sons, p. 277-293.

McCarthy, P.M., 2005, Statistical summaries of streamflow in Montana and adjacent areas, water years 1900 through 2002: U.S. Geological Survey Scientific Investigations Report 2004-5266, $317 \mathrm{p}$.

McIntosh, J.L., 1989, Use of scour prediction formulae, in Proceedings of the Bridge Scour Symposium: McLean, Va., U.S. Department of Transportation, Federal Highway Administration Research Report FHWA-RD-90-035, p. $78-100$.

Melville, B.W., 1984, Live bed scour at bridge piers: American Society of Civil Engineers, Journal of Hydraulic Engineering, v. 110, no. 9, p. 1,234-1,247.

Melville, B.W., 1995, Bridge abutment scour in compound channels: American Society of Civil Engineers, Journal of Hydraulic Engineering, v. 114, no. 10, p. 1,210-1,226. 
Melville, B.W., and Sutherland, A.J., 1988, Design method for local scour at bridge piers: American Society of Civil Engineers, Journal of Hydraulic Engineering, v. 110, no. 11, p. 1,519-1,539.

Meyer-Peter, E., and Müller, R., 1948, Formulas for bed-load transport, in Proceedings of the 2nd Meeting of the International Association for Hydraulic Structures Research: Delft, Netherlands, p. 39-64.

Molinas, Albert, 2000, User's manual for BRI-STARS (BRIdge Stream Tube model for Alluvial River Simulation): U.S. Department of Transportation Publication FHWA-RD-99-190, 228 p.

Molinas, Albert, 2003, Bridge scour in nonuniform sediment mixtures and in cohesive materials-Synthesis report: U.S. Department of Transportation, Federal Highway Administration Publication FHWA-RD-03-083, 113 p.

Molinas, A. and Abdou, M.I., 1999, Effects of gradation and cohesion on bridge scour, vol. 1, Effect of sediment gradation and coarse material fraction on clear-water scour around circular piers: U.S. Department of Transportation, Federal Highway Administration Publication FHWA-RD-99-183, 202 p.

Molinas, A. and Noshi, M.H, 1999, Effects of gradation and cohesion on bridge scour, vol. 2, Experimental study of sediment gradation and flow hydrograph effects on clearwater scour around circular piers: U.S. Department of Transportation, Federal Highway Administration Publication FHWA-RD-99-184, 94 p.

Montana Department of Transportation, 1994, Montana bridges, 1994: Montana Department of Transportation, Bridge Bureau and Transportation Planning, $212 \mathrm{p}$.

Montgomery, D.R., and Buffington, J.M., 1997, Channel-reach morphology in mountain drainage basins: Geological Society of America Bulletin, v. 109, no. 5, p. 596-611.

Mueller, D.S., 1996, Local scour at bridge piers in nonuniform sediment under dynamic conditions: Fort Collins, Colorado State University, Ph.D. dissertation, 212 p.

Mueller, D.S., and Jones, J.S., 1999, Evaluation of recent field and laboratory research on scour at bridge piers in coarse bed materials, in Richardson, E.V., and Lagasse, P.F., eds., Stream Stability and Scour at Highway Bridges, Proceedings of the Water Resources Engineering (Hydraulics) Division, American Society of Civil Engineers, [compendium of abstracts and selected papers from conferences 1991 to 1998]: Reston, Va., American Society of Civil Engineers, p. 298-310.
Mueller, D.S., and Landers, M.N., 2000, Portable instrumentation for real-time measurement of scour at bridges: U.S. Department of Transportation, Federal Highway Administration Publication FHWA-RD-99-085, 87 p.

Mueller, D.S., and Wagner, C.R., 2005, Field observations and evaluations of streambed scour at bridges: U.S. Department of Transportation, Federal Highway Administration Publication FHWA-RD-03-052, 134 p.

Mueller, E.R., Pitlick, John, and Nelson, J.M., 2005, Variation in the reference Shields stress for bed load transport in gravel-bed streams and rivers: Water Resources Research, v. 41 , no. 4 , p. $1-10$.

Nicollet, G., and Ramette, M., 1971, Affouillements au Voisinage de Piles des Pont Cylindriques Circulaires, in Proceedings of the 14th Congress of the International Association of Hydraulic Engineering and Research: Paris, France, International Association of Hydraulic Engineering and Research, p. 315-322.

Parker, Gary, Klingeman, P.C., and McLean, D.G., 1982, Bedload and size distribution in paved gravel-bed streams: American Society of Civil Engineers, Journal of Hydraulic Engineering, v. 108, no. HY4, p. 544-571.

Parker, Gary, and Klingeman, P.C., 1982, On why gravel bed streams are paved: Water Resources Research, v. 18, no. 5, p. 1,409-1,423.

Parrett, Charles, and Johnson, D.R., 2004, Methods for estimating flood frequency in Montana based on data through water year 1998: U.S. Geological Survey Water-Resources Investigations Report 03-4308, $101 \mathrm{p}$.

Rantz, S.E., and others, 1982, Measurement and computation of streamflow: U.S. Geological Survey Water-Supply Paper 2175, v. 1, 631 p.

Raudkivi, A.J., and Sutherland, A.J., 1981, Scour at bridge crossings: Wellington, New Zealand, National Roads Board, Road Research Unit, Bulletin 54, 100 p.

Richardson, E.V., and Davis, S.R., 1995, Evaluating scour at bridges ( $3 \mathrm{~d}$ ed.): U.S. Department of Transportation Publication FHWA-IP-90-017, Hydraulic Engineering Circu$\operatorname{lar} 18,204 \mathrm{p}$.

Richardson, E.V., and Davis, S.R., 2001, Evaluating scour at bridges (4th ed.): U.S. Department of Transportation, Hydraulic Engineering Circular 18, 378 p.

Richardson, E.V., Harrison, L.J., and Davis, S.R., 1991, Evaluating scour at bridges: U.S. Department of Transportation, Hydraulic Engineering Circular 18, 105 p. 
Richardson, E.V., Harrison, L.J., Richardson, J.R., and Davis, S.R., 1993, Evaluating scour at bridges (2d ed.): U.S.

Department of Transportation, Hydraulic Engineering Circular $18,132 \mathrm{p}$.

Richardson, E.V., Simons, D.B., Karaki, S., Mahmood, K., and Stevens, M.A., 1975, Highways in the river environment: U.S. Department of Transportation, Federal Highway Administration Publication FHWA-NHI-76-N005, 476 p.

Shen, H.W., Schneider, V.R. and Karaki, S.S., 1966, Mechanics of local scour: Fort Collins, Colorado State University, Civil Engineering Department, Report CER66-67HWS27, $56 \mathrm{p}$.

Sheppard, D.M., 2004, Overlooked local sediment scour mechanism: Transportation Research Board of the National Academies, Transportation Research Record, v. 1890, p. 107-111.

Turnipseed, D.P., and Sauer, V.B., 2010, Discharge measurements at gaging stations: U.S. Geological Survey Techniques and Methods, book 3, chap. A8, 87 p.

Wolman, M.G., 1954, A method of sampling coarse river-bed material: American Geophysical Union Transactions, v. 35, no. 6, p. 951-956. 
Publishing support provided by the:

Denver and Rolla Publishing Service Centers

For more information concerning this publication, contact: Director, Montana Water Science Center

U.S. Geological Survey

3162 Bozeman Ave.

Helena, MT 59601

(406) 457-5900

Or visit the Montana Water Science Center Web site at: http://mt.water.usgs.gov/ 

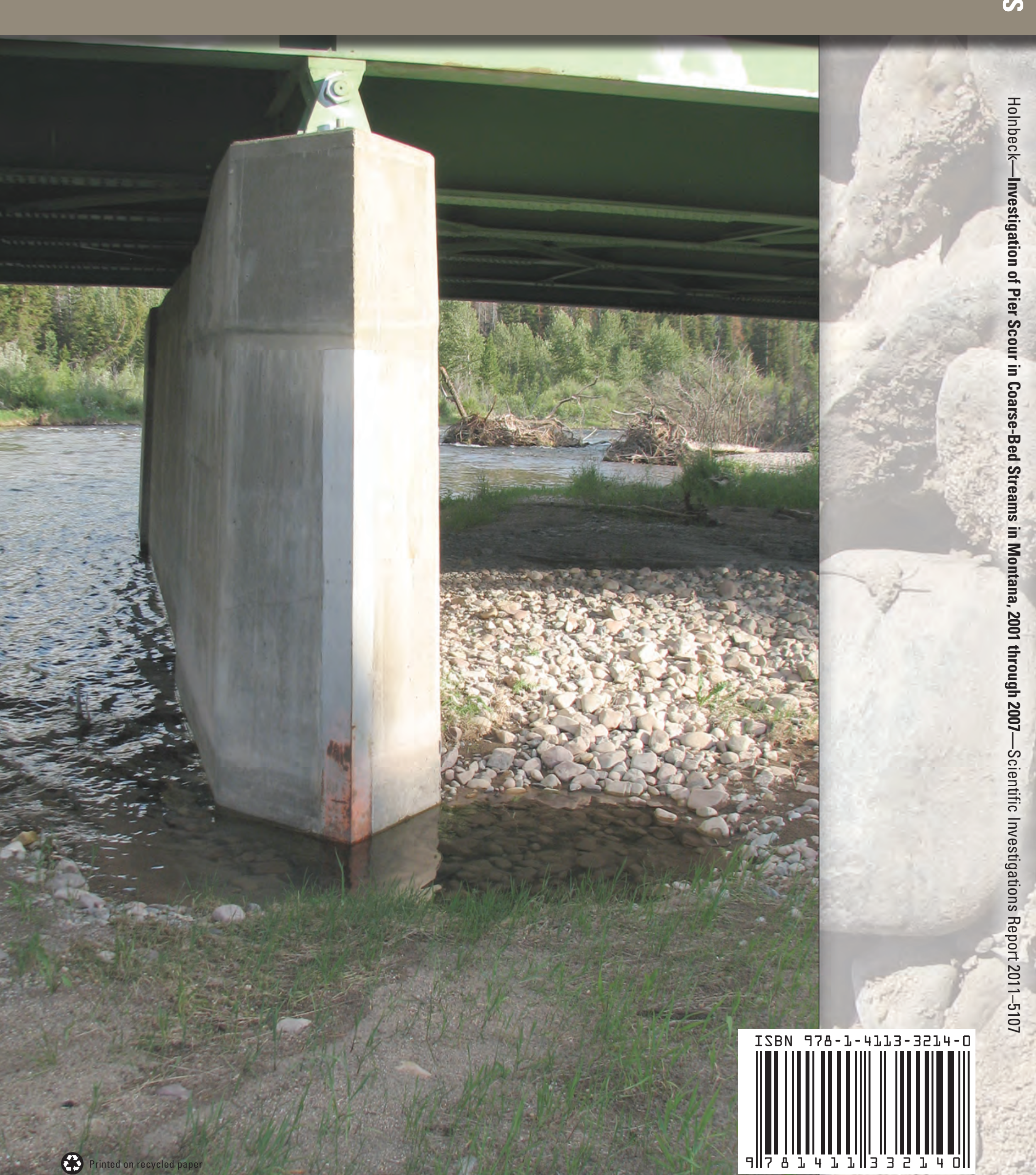

ISBN $978-1-4113-3214-0$

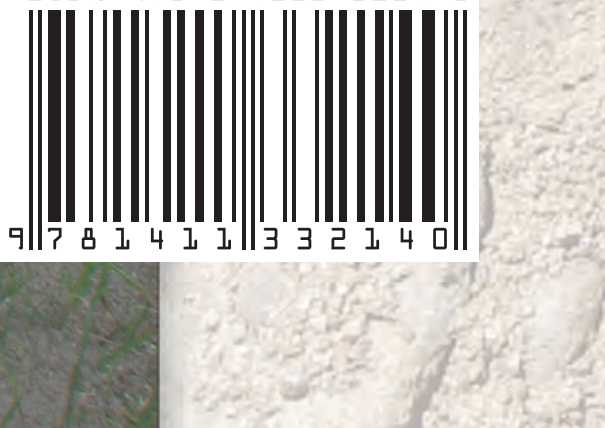

